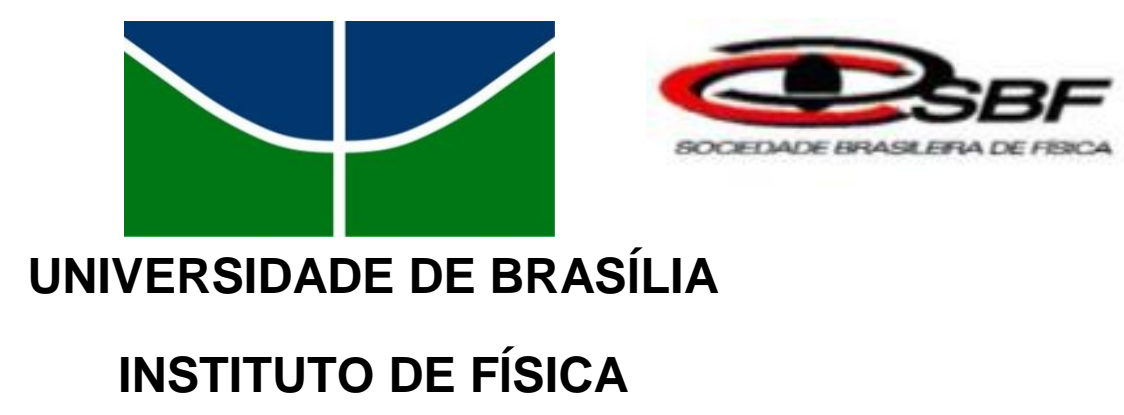

PROGRAMA DE PÓS-GRADUAÇÃO DE MESTRADO PROFISSIONAL EM ENSINO DE FÍSICA

MESTRADO NACIONAL PROFISSIONAL EM ENSINO DE FÍSICA

O ENSINO DE INÉRCIA COM DESENHOS ANIMADOS, UTILIZANDO FUTURAMA COMO FERRAMENTA LÚDICA

DIEGO VERÍSSIMO PEREIRA

BRASÍLIA

2015 

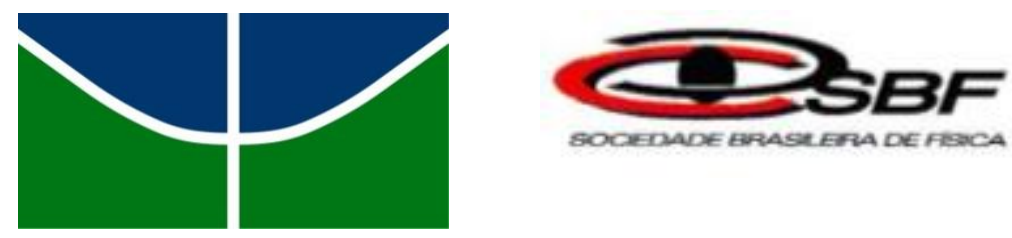

UNIVERSIDADE DE BRASÍLIA

INSTITUTO DE FÍSICA

PROGRAMA DE PÓS-GRADUAÇÃO DE MESTRADO PROFISSIONAL EM ENSINO DE FÍSICA

\author{
MESTRADO NACIONAL PROFISSIONAL EM ENSINO DE FÍSICA
}

\title{
O ENSINO DE INÉRCIA COM DESENHOS ANIMADOS, UTILIZANDO FUTURAMA COMO FERRAMENTA LÚDICA
}

\section{DIEGO VERÍSSIMO PEREIRA}

Dissertação de Mestrado apresentada ao Programa de Pós-Graduação no Curso de Mestrado Profissional de Ensino de Física (MNPEF), como parte dos requisitos necessários à obtenção do título de Mestre em Ensino de Física.

Orientadora:

Profa. Dra. Adriana Pereira Ibaldo

BRASÍLIA

2015 


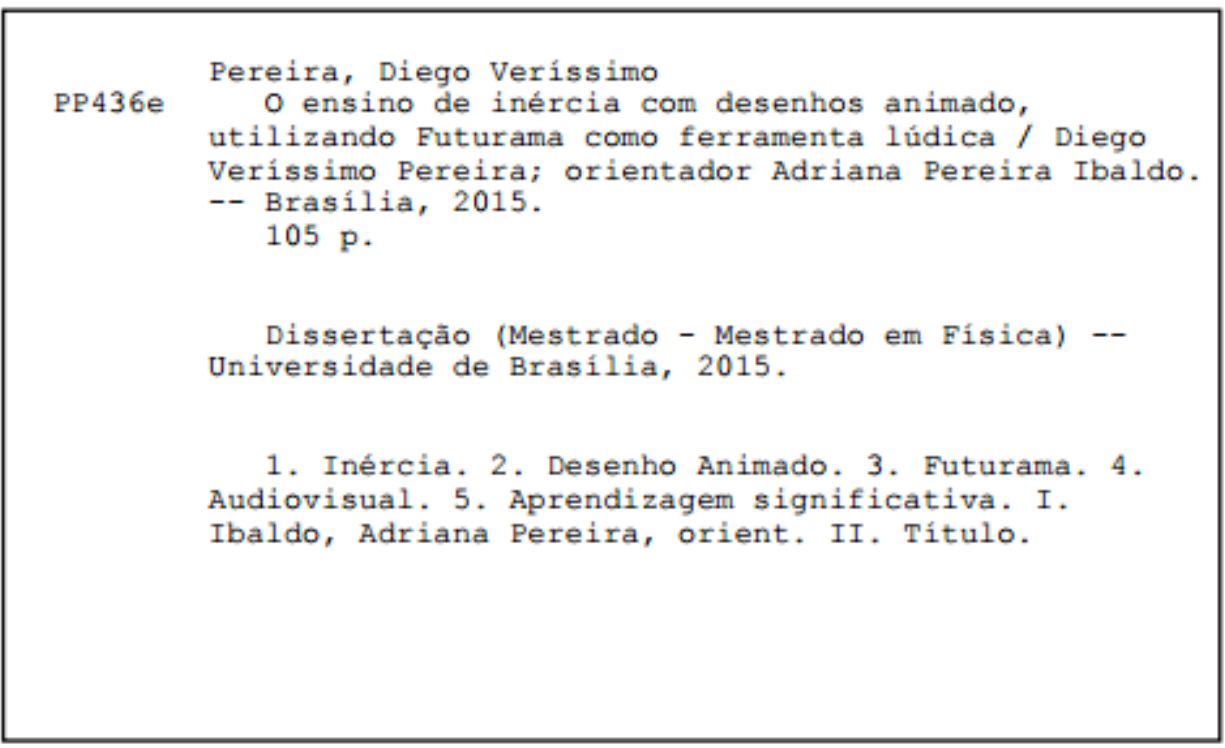


Dedico esta dissertação a Deus, a minha amada esposa Yara Verburg, por todos os momentos em que me incentivou a continuar escrevendo e aos filhos que teremos no futuro. Aos meus pais, Maria e José, que muito lutaram para que aqui eu chegasse. A minha sogra Itamar e meu sogro Cornelis que me encorajaram nesta trajetória. 


\section{AGRADECIMENTOS}

A Deus por ter me dado força e discernimento para ler o que deixou escrito nas entrelinhas do mundo.

Ao apoio de minha orientadora, Professora Doutora Adriana Pereira Ibaldo pela paciência e incentivo.

A meu amigo Bruno Gomides por ter me apresentado o desenho que me serve de base de pesquisa, Futurama.

A meu amigo Uaitan Dalcin por ter prestado assistência jurídica.

As minhas amigas Dra. Elen Gonzaga e Ma. Cristhiane Vaz por me auxiliarem e me incentivarem nessa jornada acadêmica.

A todos os professores do curso que contribuíram direta ou indiretamente para a realização deste trabalho.

Aos colegas do curso, pela resistência e união para vencer os caminhos e os descaminhos desta jornada.

A coordenadora do curso Professora Doutora Maria de Fátima Verdeaux, pelo apoio à continuidade do trabalho. 
Você sabe que não pode se divertir em um jogo a menos que conheça suas regras, seja ele um jogo de bola, um jogo de computador ou simplesmente uma brincadeira em uma festa. Da mesma forma, você não pode avaliar direito tudo - que o cerca até que tenha compreendido as leis da natureza. A física é um estudo dessas leis, que Ihe mostrará como tudo na natureza está maravilhosamente conectado. Assim, a principal razão para estudar física é aperfeiçoar a maneira como você enxerga o mundo.

(Paul G. Hewitt) 


\section{RESUMO}

Pereira, Diego Veríssimo. O Ensino de Inércia com Desenhos Animados, Utilizando Futurama como Ferramenta Lúdica. 2015. 105 f. Dissertação (Mestrado) - Universidade de Brasília - Brasília/DF, 2015.

Este trabalho apresenta o resultado da pesquisa que utilizou Futurama como um recurso audiovisual e uma ferramenta de ensino para uma abordagem lúdica do conceito de inércia referente à primeira lei de Newton no $9^{\circ}$ ano do ensino fundamental. O principal objetivo do trabalho consiste em despertar o interesse dos alunos para as disciplinas científicas, tão presentes no dia-a-dia dos estudantes. A utilização de desenhos animados para o ensino de física é uma forma de motivar seus estudos nesta disciplina, pois além de fazer uso de uma linguagem verbal e não-verbal, mais próxima da utilizada pelo discente, considera o contexto sociocultural, o que lhes desperta o interesse, requisito necessário para que ocorra uma aprendizagem significativa. Neste sentido, fazer uso de uma ferramenta presente no dia-a-dia dos alunos e com forte apelo audiovisual desponta como uma alternativa interessante e promissora, inclusive como forma de divulgação científica, que no contexto deste trabalho é vista como um meio de popularização do conhecimento científico para público não especializado. Os resultados indicam uma melhoria no aprendizado, além de maior aceitação e interesse com relação à física.

Palavras-chaves: Inércia, Desenho animado, Futurama, Aprendizagem significativa, Audiovisual, Divulgação científica. 


\begin{abstract}
Pereira, Diego Veríssimo. Teaching Inertia with Cartoons, using Futurama as an entraining tool. 2015. 105 f. Dissertation (Master) - University of Brasilia - Brasilia / DF, 2015.

This work presents the results of the research which used Futurama as an audiovisual aid and an educational tool in an entertaining approach to the concept of inertia related to Newton's first law in the 9th grade of elementary school. The main objective of this study is to arouse the interest of students to scientific subjects, so present in their daily lives. The use of cartoons to teach physics is a way to motivate students to study this subject, since it uses verbal and non-verbal language, similar to that used by the students, and it takes into consideration their socio-cultural context, which arouses their interest, requirement necessary to occur meaningful learning. In this context, using a tool with a strong audiovisual appeal that is present in students' daily lives, emerges as an interesting and promising alternative, which in the context of this work is seen as a way to popularize scientific knowledge for a nonspecialized public. The results show an improvement in learning, in addition to a greater acceptance and interest regarding physics.
\end{abstract}

Keywords: Inertia, Cartoon, Futurama, Meaningful learning, Audiovisual, Dissemination of scientific knowledge. 


\section{SUMÁRIO}

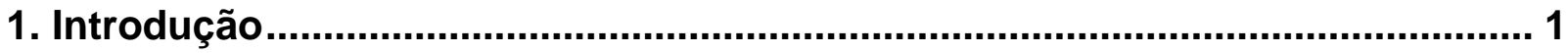

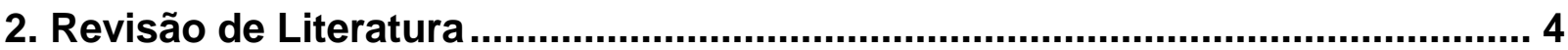

2.1 A importância do uso do audiovisual nas aulas de física .......................... 8

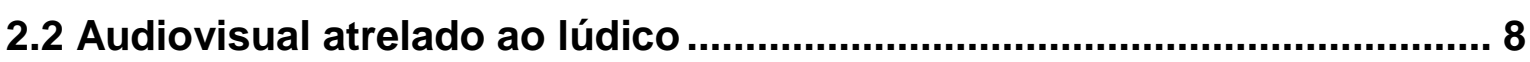

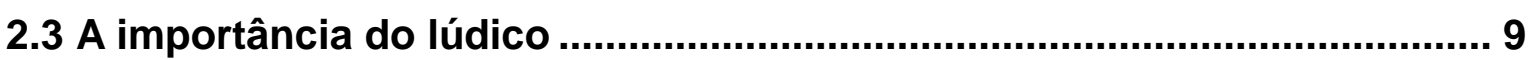

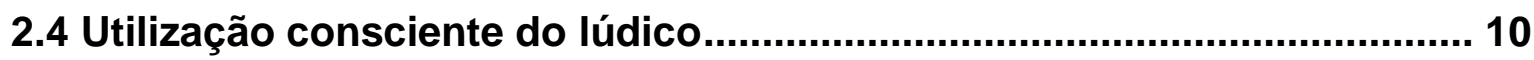

2.5 A utilização do lúdico na divulgação científica: Abordagem histórica ... 10

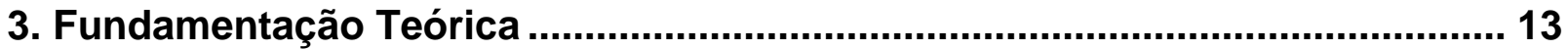

3.1 A Teoria de Vygotsky - A teoria histórico-cultural................................... 13

3.1.1 Vygotsky: A aprendizagem e o ensino......................................... 15

3.2 Teoria de Ausubel: A aprendizagem significativa ................................. 16

3.2.1 Papel do professor na aprendizagem significativa ..................... 17

3.3 Elo entre Vygotsky e Ausubel........................................................... 17

4. Proposta e Produto Educacional ................................................................... 19

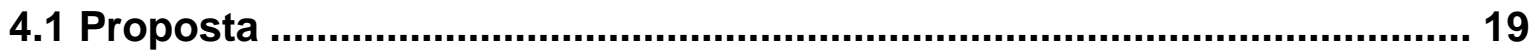

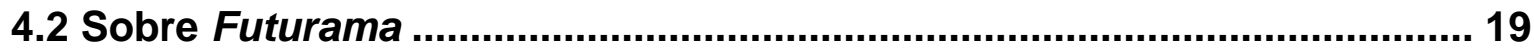

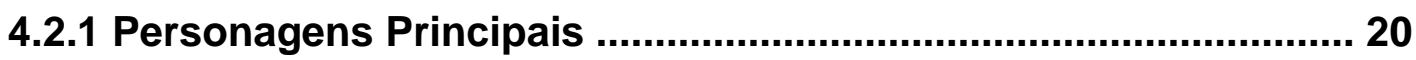

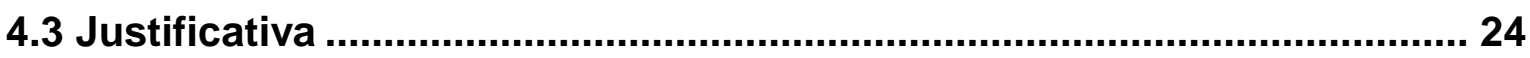

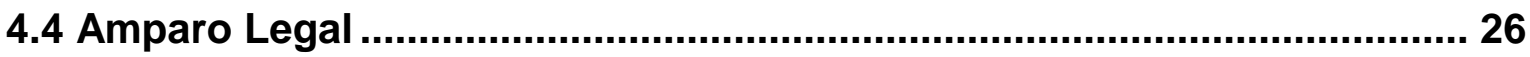

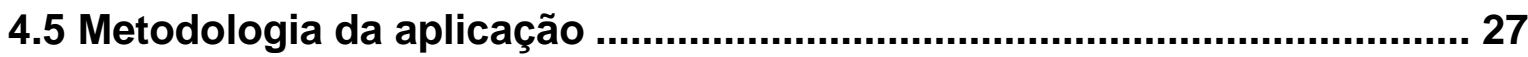

4.6 Metodologia da pesquisa (Produto: antes, durante e depois) ................ 50

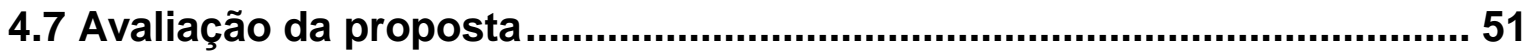

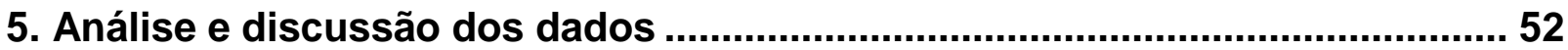

5.1 Análise e discussão dos dados do pré-questionário .............................. 52

5.2 Análise e discussão dos dados do pós-questionário................................63

5.3 Análise e discussão dos dados do questionário pós-teste ..................... 71

6. Considerações finais e perspectivas .............................................................. 75

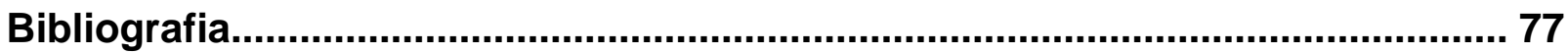

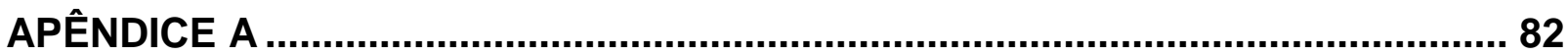

APÊNDICE B 
APÊNDICE C

APÊNDICE D 


\section{INTRODUÇÃO}

O ensino de física no Brasil precisa ser mais que um treinamento para o vestibular, segundo Moreira (2000), é importante dessa forma utilizar abordagens que permita desenvolver a mente do estudante em física. Uma maneira de fazer isso é utilizar ferramentas auxiliares em conjunto com o uso de novas tecnologias. Uma forma de motivar os discentes é utilizar recursos tecnológicos como internet, televisão e applets, os quais eles dominam e são acessíveis aos estudantes hoje em dia, pois estão no seu convívio social. A ferramenta utilizada no presente trabalho é o desenho animado Futurama, exibido na televisão (TV), recurso que está presente no cotidiano do brasileiro há algumas décadas. A televisão é muito atrativa para o jovem por ser dinâmica e, assim, as imagens acabam por ficar guardadas em sua memória.

O presente estudo inclui ainda a análise sobre a influência de desenhos que possuem conceitos físicos, apresentados na forma de programas de TV, os quais os estudantes possuem acesso. É importante fazer tal análise, pois os jovens assistem muito a televisão ao longo do dia e essas horas podem ser aproveitadas para uma alfabetização científica.

Um adolescente brasileiro assiste a televisão em média 28 horas por semana, ou seja, 4 horas diárias, de acordo com o estudo de Xavier (2014). É o dobro do recomendado pela American Academy of Pediatrics (2001), de 2 horas diárias. Uma recomendação neste trabalho é que ao menos uma fração do total de horas gastas assistindo à televisão seja empregada para atividade intelectiva.

Este trabalho explora o tema inércia, referente à Primeira Lei de Newton, no 9o Ano do Ensino Fundamental. Para tanto, são empregados episódios do desenho animado FUTURAMA, que consiste em um seriado futurístico. Na mesma categoria, é possível ainda citar os seriados Os Simpsons e The Big Bang Theory, que também podem ser utilizados. Em alguns momentos, esses seriados abordam alguns temas de física, os quais podem ser apresentados aos estudantes para que eles possam compreender melhor o universo que os cerca.

Carl Sagan comenta o momento em que decidiu ser cientista: ele ficou encantado e "despertou" para ciência quando entendeu o que são as estrelas. 
Eu fui criança num tempo de esperança. Queria ser cientista desde os primeiros dias de escola. O momento que marcou essa vontade foi quando entendi pela primeira vez que as estrelas são sóis poderosos, quando comecei a compreender que elas devem estar tremendamente distantes para surgirem como simples pontos de luz no céu. Nem sei se já conhecia a palavra ciência naquele tempo, mas queria de algum modo mergulhar em toda essa grandiosidade. Eu estava seduzido pelo esplendor do Universo, deslumbrado pela perspectiva de compreender como as coisas realmente funcionam, de ajudar a revelar mistérios profundos, de explorar novos mundos - talvez até literalmente. Tive a boa sorte de ver esse sonho em parte concretizado. Para mim, o fascínio da ciência continua tão atraente e novo quanto naquele dia, há mais de meio século, em que me mostraram maravilhas da Feira Mundial de 1939. Divulgar a ciência - tentar tornar os seus métodos e descobertas acessíveis aos que não são cientistas - é o passo que se segue natural e imediatamente. Não explicar a ciência me parece perverso. (SAGAN,2006)

Assim, divulgar a ciência para todos os tipos de público é importante para que ocorra uma alfabetização científica ${ }^{1}$ da população brasileira. Os discentes do $9^{\circ}$ ano do ensino fundamental II estão realizando os estudos introdutórios em física, e alfabetização científica neste nível de ensino permite mostrar que as ciências são acessíveis a todos.

Quando a atividade for interessante do ponto de vista do estudante, ele acaba por participar mais e fica motivado a estudar. De acordo com os Parâmetros Curriculares Nacionais (PCN), existe uma recomendação de se abordar os temas de uma forma mais interdisciplinar e contextualizada, a exemplo dos temas transversais.

Ainda no Ensino Fundamental, a matéria de Ciências apresenta preliminarmente a divisão em Química e Física no 9ำ ano, a qual se aprofundará ao longo do Ensino Médio. Neste momento, ainda que o curso de física possua caráter introdutório, é essencial despertar o interesse dos alunos, além de evidenciar a

\footnotetext{
${ }^{1}$ Alfabetização cientifica possui diversos entendimentos: pode ser entendida em três dimensões: o entendimento da natureza da ciência; a compreensão de termos e conceitos chave das ciências; e, o entendimento dos impactos das ciências e suas tecnologias. (SASSERON, 2011)
} 
conexão do conteúdo programático de física com outras disciplinas e o cotidiano dos alunos. Neste sentido, lançar mão de uma ferramenta presente no dia-a-dia dos alunos e com o apelo audiovisual, o seriado FUTURAMA, por apresentar forte caráter interdisciplinar, desponta como uma alternativa interessante e promissora. $\mathrm{O}$ projeto abrange o ensino de física com a utilização de desenhos animados, voltado para o conceito de inércia, que foi aplicado no Colégio Cor Jesu localizado em Brasília- DF.

A presente dissertação está dividida da seguinte forma: o capítulo 2 traz a revisão de literatura juntamente com a importância da utilização dos desenhos animados, situando a importância do produto. O capítulo 3 refere-se à base pedagógica utilizada na pesquisa, à luz das teorias de Vygotsky e Ausubel. $O$ capítulo 4 apresenta a justificativa da escolha do tema. O capítulo 5 discute a metodologia juntamente com os procedimentos utilizados. O capítulo 6 expõe a análise dos dados colhidos juntamente com a discussão. O capítulo 7 conclui a dissertação e apresenta as perspectivas para o trabalho como um todo. 


\section{REVISÃO DE LITERATURA}

O presente capítulo apresenta uma revisão a respeito do uso de recursos audiovisuais no Ensino de Física. Além de ilustrar, os vídeos ainda podem ser utilizados para o ensino de História da Ciência, contexto destacado por Rezende (2008). A preparação e o conhecimento do professor sobre o material utilizado, no caso vídeos, são fundamentais para poder levar os estudantes a pensar sobre o que foi visto. Os estudantes não devem ser meros ouvintes ou espectadores, devem raciocinar e perceber as leis que regem o que ocorreu.

A comunicação entre as pessoas vem mudando em todos os ambientes ao longo do tempo, e o uso das diversas tecnologias tem grande influência nesses aspectos. Cabe aos professores explicar como tais recursos tecnológicos funcionam. A busca por melhores materiais caracteriza-se desde o ano de 1963, quando o projeto PSSC (Physical Science Study Commitee), da universidade de Harvard, foi traduzido para o Português. A seguir são apresentados seriados e filmes de divulgação científica exibidos a partir da década de 1980 até os dias atuais.

A partir da década de 1980:

- Cosmos: A personal Voyage, de Carl Sagan (produção 1978 e 1979, exibição 1980);

- $\quad$ O Universo Mecânico (The Mechanical Universe), como telecurso 1986 e 1987, foi transmitido pela TV cultura no Brasil;

- $\quad$ Deus, O universo e Todo o Resto; BBC 1988.

A partir da década de 1990:

- $\quad$ O mundo de Beakman; 1994 pela TV Cultura.

- Futurama (1999) do Canal FOX.

- A partir da primeira década dos anos 2000:

- $\quad \mathrm{E}=\mathrm{mc}^{2}$ : Einstein's Big Idea, 2005 docudrama²;

- Poeira das estrelas, emissora Globo, 2006;

- $\quad$ The Big Bang Theory, seriado desde 2007;

- O universo (The Universe) desde 2007, History Channel.

\footnotetext{
2 É caracterizado por ser estar entre o drama e documentário.
} 
Na década de 2010:

- $\quad$ The Universe beyond the big bang, documentário do canal History Channel, 2010;

- Como o universo funciona (How the universe works), documentário do Canal Discovery Channel, 2010;

- Ciência em casa, do canal NatGeo, 2012.

- $\quad$ Ciência do absurdo, do canal NatGeo, 2014.

Com toda essa gama de possibilidades, as quais podem abranger temas diversos, um produto educacional o qual apresente o tema já selecionado demonstra característica importante.

A seguir, são apresentados os artigos da literatura entre os anos de 2000 a 2015 os quais retornaram a pesquisa realizada com a utilização do termo audiovisual, cinema, vídeo, desenho, ou desenho animado no título ou resumo.

Tabela 1 - Produção científica com recursos audiovisuais

\begin{tabular}{l|l} 
Autor (es) & Título do artigo
\end{tabular}

Ano

ROSA, P. R. S. O uso dos recursos audiovisuais e o ensino de 2000 Ciências.

ANDRADE, E. C.P. O professor de ciências e o cinema: 2000 possibilidade de discussão

VERGARA, D. A. ; $\quad$ O uso de um vídeo no estudo do fenômeno de 2001 BUCHWEITZ, B. refração da luz.

CLEBSCH, A. B.; Realidade ou ficção: A análise de desenhos 2004 animados e filmes motivando a física na sala de aula

OLIVEIRA, L. D. Aprendendo física com o Homem-Aranha: 2006 utilizando cenas do filme para discutir conceitos de Física no Ensino Médio 
MACHADO, C. A. Filmes de ficção científica como mediadores de 2008 conceitos relativos ao Meio-ambiente

MESQUITA, N. A.; Visões de ciência em desenhos animados: uma 2008 SOARES, M. H. alternativa para o debate sobre a construção do conhecimento cientifico em sala de aula.

REZENDE, L. A. História das ciências no Ensino de Ciências: 2008 contribuições dos recursos audiovisuais.

Fonte: REZENDE FILHO, Luiz Augusto C., Marcus Vinicius Pereira, and Alexandre C. VAIRO. "Recursos Audiovisuais como temática de pesquisa em periódicos brasileiros de Educação em Ciências." Revista Brasileira de Pesquisa em Educação em Ciências 11.2 (2011): 183-204.

Tabela 2 - Produção científica com recursos audiovisuais

\begin{tabular}{|c|c|c|}
\hline Autor (es) & Título do artigo & Ano \\
\hline $\begin{array}{l}\text { TIMM, M. I. ; } \\
\text { MIKICH, A. B.; } \\
\text { AZEVEDO, A. M. } \\
\text { JUNIOR, P. A. C. }\end{array}$ & $\begin{array}{l}\text { Vídeos agregam valor ao trabalho do professor } \\
\text { de ciências da saúde }\end{array}$ & 2008 \\
\hline BORRÁS, F. J. G. & $\begin{array}{l}\text { Las escenas cinematográficas: una herramienta } \\
\text { para el estudio de las concepciones alternativas } \\
\text { de física y química. }\end{array}$ & 2011 \\
\hline LOPEZ, R. R. & $\begin{array}{l}\text { Aplicações audiovisuais sobre divulgação } \\
\text { cientifica: uma experiência para TV com o } \\
\text { programa "Física na prática" }\end{array}$ & 2011 \\
\hline LISBOA, I. A. & $\begin{array}{l}\text { O uso do desenho animado como recurso } \\
\text { didático - Filme Rio }\end{array}$ & 2012 \\
\hline $\begin{array}{l}\text { SILVA, I. } \\
\text { MERCADO, L. P. L. }\end{array}$ & $\begin{array}{l}\text { Contribuições didáticas da produção e } \\
\text { compartilhamento de vídeos em aulas de Física. }\end{array}$ & 2013 \\
\hline
\end{tabular}


Os trabalhos acima citados não são apenas na área de física, sendo utilizados nas áreas que abordam desde medicina à educação ambiental. Estes sugerem a utilização dos recursos audiovisuais e mostram como esses recursos conseguem corroborar para o ensino com o apelo visual e linguagem.

O uso de recursos audiovisuais como TV, retroprojetor, Youtube, abordado no trabalho de Rosa (2000) enfatiza a motivação dos estudantes e a função do audiovisual nas aulas de ciências e fornece uma sugestão de regras gerais para sua utilização. Já Andrade (2000) faz uso do cinema em sala de aula como forma de crítica à sociedade e recomenda utilizar um filme específico para discutir um conteúdo de biologia. Vergara e Buchweitz (2001) utilizam um vídeo para explicar o fenômeno da refração da luz e descrevem em seu trabalho que os estudantes ficaram mais motivados e participativos uma vez que o vídeo foi mostrado e depois a aula foi ministrada. Clebsh (2004) utiliza trechos de filmes e de um desenho animado que fazem uso de assuntos presentes no cotidiano dos estudantes. Oliveira (2006) utilizou um filme para ensinar aos estudantes conceitos de física e percebeu que os estudantes mostravam mais interesse com os conteúdos que faziam uso dessa abordagem. O trabalho de Machado (2008) aborda o meio ambiente no Brasil em filmes, com potencial para serem usados em sala de aula. Mesquita (2008) utilizou desenhos animados para perceber como é a visão dos estudantes com relação às ciências e aos cientistas. Rezende (2008) faz uma abordagem histórica de como os recursos audiovisuais colaboraram para o ensino de ciências, mostrando suas influências.

Timm (2008) mostra o uso de vídeos sobre uma ótica diferente, uma vez que mostra a importância desses recursos para os profissionais da saúde, mostrando que uma cirurgia filmada pode ajudar os estudantes por possuir alto grau de abstração. Com mesmo intuito, Borrás (2011) utiliza trechos de filmes para motivar a discussão de conteúdos de física e química, questionando os estudantes se uma situação é ou não possível.

Já Lopez (2011) analisa a utilização de recursos audiovisuais para a divulgação científica. Tal ponto de vista é compartilhado por Lisboa (2012), que faz uma análise de erros conceituais no filme Rio e o mostra como ferramenta de ensino para a educação ambiental. Silva (2013) produziu e compartilhou vídeos como 
recurso de ensino, por meio do Youtube mostrando assim o impacto nas aulas de física ao se utilizar tal recurso.

\subsection{A IMPORTÂNCIA DO USO DE AUDIOVISUAL NAS AULAS DE FÍSICA}

Um material audiovisual não serve apenas para ilustrar um conceito, pois permite uma experiência indireta do estudante com determinada situação. É através deste recurso que se dá a aproximação entre o indivíduo e a situação a ser analisada. Dessa maneira, o audiovisual pode contribuir com o processo de ensino e aprendizagem.

O mais importante em uma abordagem lúdica é fazer com que o estudante perceba que está melhorando sua capacidade intelectiva. Os recursos audiovisuais precisam ser mais do que meras formas de ilustrar a aula; eles podem e devem ser utilizados para que o estudante pense sobre um assunto e analise se determinadas situações são possíveis. Os desenhos carregam a característica de serem uma maneira não usual ${ }^{3}$, a qual permite desenvolver habilidades em diferentes áreas do conhecimento. O audiovisual corrobora com o ponto de vista defendido pelo PCN que recomenda a utilização de outros meios além do livro didático.

\subsection{AUDIOVISUAL ATRELADO AO LÚDICO}

O recurso audiovisual pode estar interligado ao lúdico. O grau de abstração do lúdico é bem elevado e ainda pode conter temas transversais, os quais contribuem para uma formação completa do indivíduo. O trabalho de Rezende (2011) mostra que ele funciona como um facilitador/estimulador de aprendizagem, pois contribui para uma aprendizagem significativa.

O lúdico pode trazer à aula um momento de felicidade, seja qual for a etapa de nossas vidas, acrescentando leveza à rotina escolar e fazendo com que

\footnotetext{
${ }^{3} \mathrm{O}$ termo não usual é utilizado pois poucos trabalhos de utilizaram desenhos animados em suas pesquisas.
} 
o aluno registre melhor os ensinamentos que lhe chegam, de forma mais significativa (ROLOFF, 2013, p. 2).

Dessa forma, os desenhos animados não possuem a função apenas de passatempo ou de deixar os adolescentes quietos, mas podem levar o adolescente a compreender melhor o ambiente que o cerca. Assim, o lúdico se adequa aos objetivos dos PCN, que sugere no seu texto a diferenciação entre as fontes de informação, assim como a interação com diversas áreas durante o planejamento das aulas de modo a utilizar situações interpretativas de interesse aos alunos.

\subsection{A IMPORTÂNCIA DO LÚDICO}

O lúdico não é oposto ao estudo e pode ser uma ótima ferramenta caso seja utilizado de maneira consciente, pois ocorre um estímulo da atividade mental e social dos alunos, uma vez que força o estudante a extrapolar e se distanciar do concreto.

As atividades lúdicas estão inseridas no ambiente escolar desde a pré-escola, momento em que está relacionado apenas com o brincar. Desde Platão já se faz presente a sugestão de se utilizar jogos com 0 intuito de estimular 0 desenvolvimento intelectual das crianças, de acordo com MARAFON (2009).

A utilização desses recursos é importante para o trabalho pedagógico, uma vez que eles podem fornecer exemplos raros de serem produzidos. Sua utilização é incentivada pelos PCN, pois:

Assim, o estudo das Ciências Naturais de forma exclusivamente livresca, sem interação direta com os fenômenos naturais ou tecnológicos, deixa enorme lacuna na formação dos estudantes. Sonega as diferentes interações que podem ter com seu mundo, sob orientação do professor. Ao contrário, diferentes métodos ativos, com a utilização de observações, experimentação, jogos, diferentes fontes textuais para obter e comparar informações, por exemplo, despertam o interesse dos estudantes pelos conteúdos e conferem sentidos à natureza e à ciência que não são possíveis ao se estudar Ciências Naturais apenas em um livro. (BRASIL, 1988, p. 27) 
Dessa forma, percebe-se que o lúdico é importante para o processo de ensino-aprendizagem, e sua utilização como recurso de ensino há muito tempo se faz presente. Porém, para sua utilização profícua, é necessário ficar claro para os estudantes a aquisição do conhecimento.

\subsection{UTILIZAÇÃO CONSCIENTE DO LÚDICO}

A utilização consciente do lúdico é importante, o professor é responsável por despertar o aprendiz para a própria disciplina, com aulas planejadas e bem estruturadas e que, se possível, que os recursos audiovisuais sejam utilizados de maneira estejam presente, pois o aprendiz não aprende exclusivamente na escola. Quando se pretende utilizar recursos lúdicos em sala de aula, as atividades precisam ser bem elaboradas, pois o estudante não pode apenas se divertir, nessas aulas o professor precisa explorar conteúdo.

O lúdico permite ao professor perceber se a turma está ou não aprendendo, uma vez que fica mais fácil organizar e planejar atividades para que o estudante alcance o conhecimento necessário. Sua utilização poderá desencadear uma relação entre o interesse do estudante e o que foi ensinado, podendo assim ocorrer uma aprendizagem significativa, ao invés de memorização para uma avaliação. Para Rubem Alves (2001), o estudante não se recorda da matéria ministrada, não por causa da falta de memória, mas por não ter significado relevante, uma vez que o estudante não sabe para que ela serve.

\subsection{A UTILIZAÇÃO DO LÚDICO NA DIVULGAÇÃO CIENTíFICA: ABORDAGEM HISTÓRICA}

A divulgação científica não é algo recente, é muito importante, e Francisco (2005) utiliza frase de Einstein, que diz:

A comunidade dos pesquisadores é uma espécie de órgão do corpo da humanidade. Esse órgão produz uma substância essencial à vida, que deve ser fornecida a todas as partes do corpo, na falta da qual ele perecerá. Isso 
não quer dizer que cada ser humano deva ser atulhado de saberes eruditos e detalhados, como ocorre frequentemente em nossas escolas, nas quais [0 ensino das ciências] vai até o desgosto. Não se trata também do grande público decidir sobre questões estritamente científicas. Mas é necessário que cada ser humano que pensa tenha a possibilidade de participar com toda lucidez dos grandes problemas científicos de sua época, mesmo se sua posição social não lhe permite consagrar uma parte importante de seu tempo e de sua energia à reflexão científica. É somente quando cumpre essa importante missão que a ciência adquire, do ponto de vista social, o direito de existir. Einstein, Berliner Tageblatt, 20 de abril de 1924

O intuito, da divulgação científica de acordo com MASSARANI (2002):

- Explicar em termos gerais para a comunidade contribuindo para a alfabetização científica.

- Elevar a compreensão da comunidade sobre ciência favorecendo dessa forma o diálogo entre a comunidade científica e a sociedade, combatendo mitos criados por leigos.

- Despertar pessoas para a área das ciências, a partir da compreensão das ciências no geral, mostrando que a ciência não é absoluta e que algumas concepções mudam ao longo do tempo.

Os objetivos da divulgação científica passam por uma simplificação de termos e conceitos, além de experiências que ilustram conceitos e teorias, além de fazer parte das mudanças sociais que a ciência propicia. Dessa maneira, os desenhos animados vão ao encontro de tais objetivos, podendo ser utilizados para a divulgação da ciência.

A divulgação científica não é algo recente. Os museus ${ }^{4}$, por exemplo, nasceram da ideia de demonstração de riquezas para amigos dos proprietários das obras. Historicamente, o ser humano coleciona objetos de seu interesse, aparecem relatos de nobres que possuíam vasta galeria de obras de arte que demonstravam

\footnotetext{
${ }^{4} \mathrm{O}$ termo museu vem do latim "museum" que por sua vez se origina do grego "mouseion", denominação, na antiga Grécia, do templo ou santuário das musas. Segundo a mitologia grega havia nove musas que presidiam as chamadas artes liberais: história, música, comédia, tragédia, dança, elegia, poesia lírica, astronomia e a poesia épica e a eloquência. $O$ termo estava mais ligado ao clima ou à atmosfera do local do que às suas características físicas. Era sobretudo um lugar de inspiração onde a mente podia se desligar da realidade cotidiana (GASPAR, 1993, p. 7)
} 
poder, pois na época o sistema monetário não era estável. Na Idade Média a Igreja Católica já utilizava obras de arte com o objetivo de transmitir mensagens religiosas, artísticas e educacionais, através de quadros e vitrais. Os nobres acabavam por adquirir materiais artísticos e a querer exibi-los, além, é claro, de guardá-los de forma adequada, dessa forma nascem as galerias de arte no século XVII.

As pessoas são naturalmente curiosas e com a abordagem organizada e interativa o número de museus aumentou aproximadamente 6,5 vezes entre os anos de 1917 e 1934, de acordo com Gaspar (1993). A interação é importante para o visitante, pois ele acaba por se divertir e aprender; além disso, o visitante sente-se mais motivado, pela abordagem lúdica e agradável.

Assim, percebe-se que para terem notoriedade, alguns museus se utilizam de ferramentas lúdicas e interativas para popularização da ciência como por exemplo o exploratorium e a academia em San Francisco (EUA) ou o museu de ciência de Santiago no Chile. Dessa forma, depreende-se que, se o mediador utilizar tais ferramentas, os estudantes terão mais interesse e mais vontade de assistir as aulas.

Pode-se citar Faraday que, de acordo com Maxwell, é "químico, filósofo e estudioso de eletricidade". Dedicou parte de sua vida para a divulgação científica ministrando palestras com experimentos para um público diverso. Faraday relata na primeira conferência do livro: "A história química de uma vela / Forças da Matéria", que gostaria de repetir os experimentos anualmente devido ao grande interesse que despertava no público que assistia a suas palestras. Essas palavras permitem concluir que, quando o público está interessado, o palestrante percebe e a atividade torna-se prazerosa para ambos 


\section{FUNDAMENTAÇÃO TEÓRICA}

Neste capítulo, é feita uma breve discussão sobre as teorias que fundamentam o presente trabalho com relação ao ensino e a aprendizagem. Serão apresentadas as teorias de Vygotsky, Ausubel e alguns elementos que possam contribuir para o ensino de física.

\subsection{TEORIA DE VYGOTSKY - A TEORIA HISTÓRICO-CULTURAL}

A teoria de Vygotsky possui quatro fundamentos:

- Os Instrumentos e Signos.

- A mediação.

- A internalização do conhecimento.

- As zonas de desenvolvimento.

O instrumento dá ao ser humano a possibilidade de conhecer o mundo ao seu redor, atuar nele e transformá-lo. Já os signos são, de acordo com o Dicionário Houaiss (2013), "qualquer objeto, forma ou fenômeno que representa algo diferente de si mesmo". Tal característica dos signos é fundamental, pois permite aos seres humanos a descontextualização, indispensável para que ocorra o desenvolvimento dos processos mentais superiores.

A linguagem é um signo de grande relevância, pois por meio dela ocorre a maioria das interações sociais. Ela permite que as pessoas se desprendam do concreto e comecem a adquirir um grau de abstração, o qual é essencial na disciplina física. A capacidade de construir instrumentos e signos, que podem sofrer mudanças ao longo do tempo, é que faz a distinção entre o homem e os outros animais. O indivíduo apropria-se de instrumentos e signos que serão usados e aprimorados por toda a sua vida, para facilitar sua adaptação à natureza.

A mediação é caracterizada pela interação, por meio do uso de instrumentos e signos, entre os seres humanos entre si e deles com o mundo. A interação social permite a conversão do processo de desenvolvimento em funções mentais superiores que são para Vygotsky (1988) pensamento, linguagem e comportamento. 
O cerne de sua teoria é caracterizado por não poder existir desenvolvimento cognitivo sem considerar o contexto social em que o estudante está inserido.

É no momento da interação social que ocorre o desenvolvimento das funções mentais superiores, possibilitando a internalização dos conceitos, não o contrário. $O$ desenvolvimento cognitivo consiste na conversão de interações sociais em processos mentais. A conversão das relações sociais em funções psicológicas se dá por meio da mediação, e é o professor quem orienta o educando. Portanto, o professor é essencial segundo essa teoria, uma vez que é na interação social que ocorre a estimulação dos processos mentais superiores. Cabe então ao professor oferecer aos seus estudantes contato com instrumentos que possam colaborar com várias formas de interagir, interpretar e desvendar, podendo dessa forma preparar o educando para ler e entender os diversos signos. Ao se apropriar de instrumentos e signos por meio da interação social, o educando se desenvolve.

Ao internalizar os instrumentos que são orientados externamente e os signos que são orientados internamente, o ser humano se desenvolve, pois as interações sociais foram convertidas em relações mentais, ou seja, o desenvolvimento do pensamento da criança parte do social para $\mathrm{o}$ individual. À medida em que as interações são convertidas, ocorre uma mudança interna no educando. A interação implica necessariamente que todos (estudante e professor) devam participar no processo educativo.

Vygotsky separa os níveis de desenvolvimento em dois, que são:

- $\quad$ Nível de desenvolvimento real

É caracterizado pelos problemas que uma criança consegue resolver sozinha, pois os processos mentais superiores já estão formados.

- $\quad$ Nível de desenvolvimento potencial

É caracterizado pelos problemas que uma criança consegue resolver com auxílio de outros, pois os processos mentais superiores ainda estão em processo de formação. 


\subsubsection{VYGOTSKY: A APRENDIZAGEM E O ENSINO}

Vygotsky sugere que 0 aprendizado ocorra dentro da zona de desenvolvimento proximal, para que, com auxílio, a criança consiga desenvolver os processos mentais superiores, e por meio da interação social sejam internalizados conhecimentos que possam tornar-se parte do desenvolvimento real da criança. Existem dois limites para o nível de desenvolvimento proximal. $O$ inferior é definido pelo nível de desenvolvimento real. O superior é definido pelo ensino formal ou informal. Desta forma é possível perceber que o mais importante e a interação, na teoria de Vygotsky

O papel do professor é fundamental para a teoria de Vygotsky, uma vez que a conversão das interações sociais em funções mentais superiores não é direta, mas sim mediada por meio do uso instrumentos e signos. Nessa mediação ocorre a conversão de interações sociais em processos mentais, uma vez que o professor é um estimulador entre o aluno e o conhecimento. O professor, na mediação, é o integrante que possui amadurecidos conceitos sobre determinado tema, enquanto 0 estudante está em processo de amadurecimento.

O papel do professor de acordo com os Parâmetros Curriculares Nacionais do ensino fundamental é similar a de Vygotsky

\footnotetext{
Dizer que o aluno é sujeito de sua aprendizagem significa afirmar que é dele o movimento de ressignificar o mundo, isto é, de construir explicações, mediado pela interação com o professor e outros estudantes e pelos instrumentos culturais próprios do conhecimento científico. Mas esse movimento não é espontâneo; é construído com a intervenção fundamental do professor. (BRASIL, 1998, p. 28)
}

Para ocorrer desenvolvimento cognitivo, o estudante precisa de significados semelhantes aos do professor e a este cabe a tarefa de verificar se o estudante possui uma visão aceita sobre determinado conteúdo. A aprendizagem não é sinônimo de desenvolvimento, apesar de ser necessária para que ocorra o desenvolvimento. 


\subsection{TEORIA DE AUSUBEL - A APRENDIZAGEM SIGNIFICATIVA}

A teoria da aprendizagem significativa de Ausubel é fundamentada na aprendizagem cognitiva, que consiste no armazenamento organizado de conceitos na mente do estudante, criando dessa maneira a sua estrutura cognitiva. A teoria da aprendizagem significativa afirma que um novo conceito é assimilado (ancorado) em uma estrutura preexistente, definida por Ausubel como subsunçor. As informações são armazenadas de maneira sistemática e hierárquica e os conceitos mais específicos estão relacionados com elementos gerais.

Quando um conceito é assimilado na estrutura cognitiva do aluno, o subsunçor é ampliado. Para que novos conceitos continuem sendo assimilados, devem ocorrer conflitos cognitivos em que conceitos pré-existentes e novos entrem em choque, sofrendo modificações pela interação entre ambos, assim evitando a estagnação.

Os requisitos para que ocorra a aprendizagem significativa são:

- O aluno precisa estar disposto a aprender;

- Uma estrutura cognitiva adequada que permita a adaptação de conhecimento prévio;

- $O$ instrumento de ensino precisa ser potencialmente significativo, tornando dessa maneira o ambiente propicio à aprendizagem significativa.

Depreende-se das condições necessárias que, para que ocorra a aprendizagem significativa, os estudantes precisam primeiramente ter interesse, pois este tem impacto direto na sua aprendizagem, e o professor precisa estimular tal interesse. O professor desempenha papel importante, pois é o motivador e verificador dos conhecimentos prévios do estudante para que possa ensiná-lo de forma adequada.

A eficácia da aprendizagem significativa depende do professor e do estudante. O professor tem funções que são:

- Verificar os subsunçores que o aluno possui;

- Ensinar de maneira que os recursos facilitem a aquisição da estrutura conceitual da matéria; 
- Planejar de modo hierárquico os conceitos de forma que eles sejam apresentados desde os menos específicos até os mais específicos.

\subsubsection{PAPEL DO PROFESSOR NA APRENDIZAGEM SIGNIFICATIVA}

Segundo a abordagem de Ausubel, o fator mais importante é o conhecimento prévio do estudante, e cabe ao professor descobrir se existem ou não tais conhecimentos. Caso não existam, a recomendação de Moreira (1999) é ajudar o estudante a construir os subsunçores básicos necessários, ou então, utilizar organizadores prévios, que possam servir como elo entre o que o aprendiz sabe e o que ele precisa saber.

No caso dos estudantes do 9ำ Ano do Fundamental, que estão começando os estudos de física, a função primordial do professor é verificar os subsunçores que o aluno possui. Se não os possui, ajudá-lo a adquiri-los. Também cabe ao professor avaliar se o que o aluno sabe está coerente com o conteúdo a ser ministrado.

Para ensinar o conceito de inércia, será preciso retomar os conceitos de movimento, repouso e referencial, conhecimentos prévios essenciais para a compreensão desse conceito.

\subsection{ELO ENTRE VYGOTSKY E AUSUBEL}

Vygotsky e Ausubel são cognitivistas. O elo entre eles é percebido no momento em que ambos levam em consideração a linguagem. Para a teoria de Vygotsky, a linguagem é o mais importante signo, enquanto para a teoria de Ausubel, a linguagem é um importante facilitador da aprendizagem significativa.

O desenho animado foi utilizado no produto educacional por fazer uso de linguagem verbal e não verbal. O principal papel do desenho é motivar os estudantes, fator indispensável para Ausubel, e utilizar elementos do contexto social em que o estudante está inserido, de acordo com Vygotsky. Tal relação também se faz presente nos Parâmetros Curriculares Nacionais do Ensino Fundamental. Em 
seu texto, é estabelecido que deve ser observado o desenvolvimento cognitivo dos estudantes levando em consideração as diferentes experiências vivenciadas, a idade, a identidade cultural e a social. Os conteúdos podem ser adaptados de acordo com a realidade local, de maneira que potencializem a aprendizagem significativa. 


\section{PROPOSTA E PRODUTO EDUCACIONAL}

\subsection{PROPOSTA}

O ensino de física no Brasil precisa ser modificado para que possa se tornar mais agradável para o estudante. Desta forma foi elaborado como produto a cartilha do professor intitulada "O Ensino de inércia com desenhos animados, com a utilização do desenho Futurama como ferramenta lúdica", que foi criada com o intuito de incentivar e estimular os estudantes nos seus estudos introdutórios da disciplina Física, de modo a desenvolver seu gosto por tal disciplina ao relacioná-la a desenhos animados. Assim, por meio de tal relação, mostra-se ao aluno que a física é uma disciplina presente no seu cotidiano e que, ao compreender mais esses conceitos, ele estará compreendendo melhor o universo que o cerca. Portanto, os pilares desse trabalho consistem em mostrar ao estudante que ele pode aprender se divertindo e também que o desenho animado é uma ferramenta que possui potencial para motivar os estudantes para as carreiras científicas.

Ressalta-se que a preparação e o conhecimento do professor sobre o material utilizado são fundamentais para poder levar os estudantes a pensar sobre o que foi visto. Os estudantes não devem ser meros ouvintes, eles devem raciocinar e perceber as leis que regem certas situações. Neste caso, o material utilizado (produto) pretende ajudar o professor a criar meios para os alunos entenderem o conceito de inércia, pois funciona como uma ferramenta de ensino e permite que o professor mostre ao estudante de forma lúdica a primeira lei de Newton.

\subsection{SOBRE FUTURAMA}

Dos mesmos produtores de "Os Simpsons", Futurama é um desenho animado que conta a história de um garoto, Philip J. Fry, que foi congelado no dia 31 de dezembro de 1999 e ficou congelado por 1000 anos, acordando no dia 31 de dezembro de 2999. Ele conhece Leela, uma ciclope, a única da espécie até o momento, que trabalha na criogenia. Ela o informa que um primo de seu sobrinho está vivo. Após fugir dela, Fry encontra Bender, um robô, em uma fila e após muita 
confusão eles acabam por se encontrar com o único parente vivo de Fry, o Professor Hubert J. Farnsworth. O professor Farnsworth tem uma empresa de entregas e pode oferecer emprego a todos, pois precisa de uma nova tripulação que já conta com Doutor Zoidberg e Hermes Conrad. Assim, a nova tripulação acaba vivendo uma série de aventuras, as quais podem ser analisadas de várias perspectivas e onde vários conceitos físicos podem ser explorados, em especial o conceito de inércia.

\subsubsection{Personagens principais.}

Figura 01 - Fry

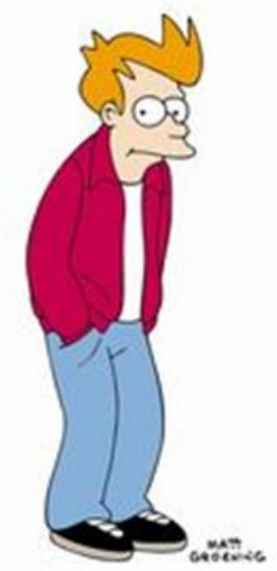

Fonte: site: disponível em: http://pt.mlp.wikia.com/wiki/Ficheiro:Fry 660.jpg Acesso em 20/10/2015.

FRY - Philip J. Fry é um dos personagens principais de Futurama. Ele era um entregador de pizza e não gostava do emprego. Na virada do ano 1999, ele é vítima de um trote e cai em um tubo criogênico, ficando congelado por 1000 anos. Ao ser descongelado conhece Turanga Leela, uma ciclope que informa que existe um parente seu vivo, o Doutor Hubert J. Farnsworth, e depois tenta entregar a ele um chip de profissão. Quando Fry descobre que seria entregador, ele se revolta e foge. $\mathrm{Na}$ fuga, conhece Bender, que se torna o seu melhor amigo. Após a fuga, Leela precisa ir atrás de Fry para entregar o chip, mas percebe que não gosta de sua própria profissão e acaba por ser contratada por Hubert J. Fry como capitã de uma nave, em uma empresa de entregas intergalácticas.

Figura 02 - Leela 


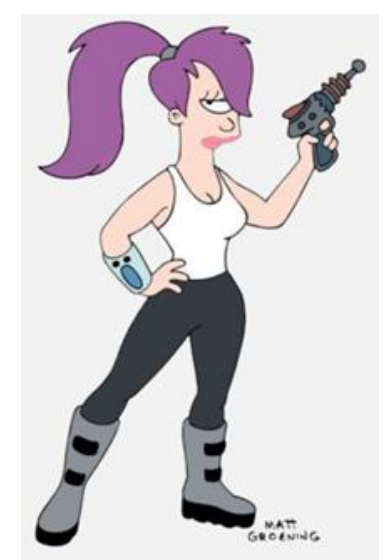

Fonte: site: disponível em: http://futurama.wikia.com/wiki/Turanga Leela. Acesso em 20/10/2015.

LEELA - Turanga Leela pensa que é a única ciclope da espécie. Ela foi abandonada por seus pais em um orfanato e pensa que é uma alienígena. $\mathrm{Na}$ verdade, Leela é uma mutante, que foi colocada para adoção por seus pais para ter uma vida melhor. Durante seu período no orfanato, ela sofreu muito preconceito por ter apenas um olho. Ela somente superou tal preconceito ao começar a praticar artes marciais. Depois começou a trabalhar na criogenia até que conheceu Fry e se tornou capitã da nave Planeta Expresso.

Figura 03 - Bender

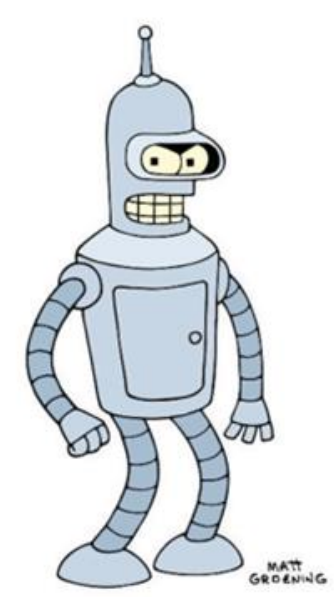

Fonte: site: disponível em: http://futurama.wikia.com/wiki/Bender. Acesso em 28/10/2015.

BENDER - Bender Bending Rodriguez é um robô programado para entortar vigas. Bender foi criado em Tijuana, México, em uma das fábricas de robôs e tem apenas 4 anos. Ele bebe bastante e fuma para parecer moderno. Bender conheceu 
Fry ${ }^{5}$ em uma cabine de suicídio, e logo ficam amigos. Bender odeia os humanos, exceto Fry e os membros da nave.

Figura 04 - Farnsworth

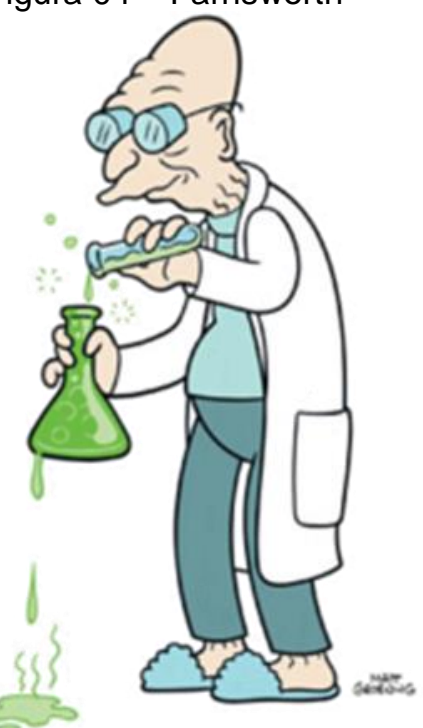

PROFESSOR FARNSWORTH - É o dono da empresa de entregas Planeta Expresso. Ele é bastante velho e tem 165 anos de idade. O professor é um dos três parentes vivos de Fry. Ele é um cientista que cria muitas coisas e discute muitas vezes com um ex-aluno.

Figura 05 - Amy

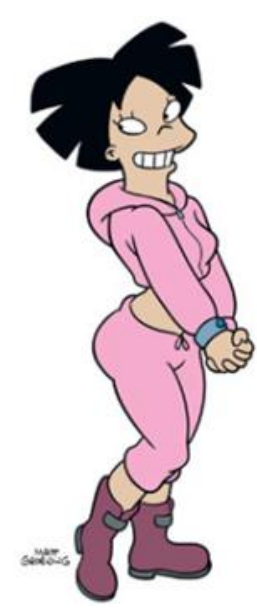

Fonte: site: disponível em: http://futurama.wikia.com/wiki/Amy. Acesso em 28/10/2015.

AMY - Amy Wong é uma jovem marciana que divide seus estudos na universidade de marte com o estágio na Planeta Expresso. Ela trabalha na empresa

${ }^{5}$ Fry não sabia que estava em uma cabine de suicídio. 
pois possui o mesmo tipo de sangue que o professor Farnsworth. No episódio: Que Droga, Katz! Amy recebe seu doutorado em Física aplicada depois de resolver uma situação complicada.

Figura 06 - Hermes

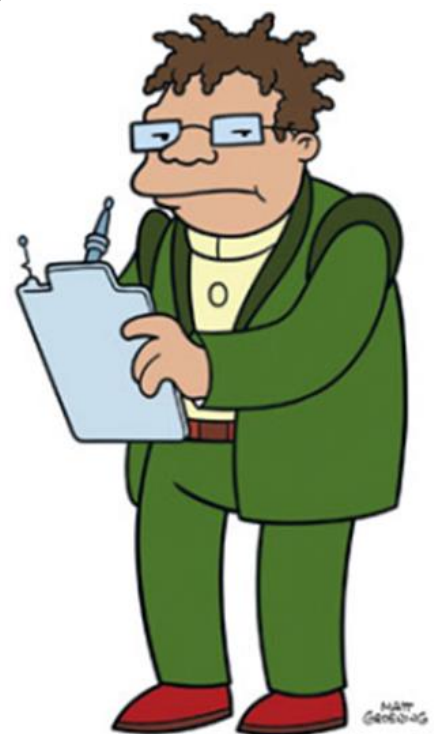

Fonte: site: disponível em: http://futurama.wikia.com/wiki/Hermes. Acesso em 28/10/2015.

HERMES - Hermes Conrad é um burocrata jamaicano. Ele é o contador na empresa Planeta Expresso e tem medo de errar, pois isso reduz seu nível de burocrata. Hermes já participou também dos jogos olímpicos, mas teve alguns problemas e por isso deixou de ser atleta.

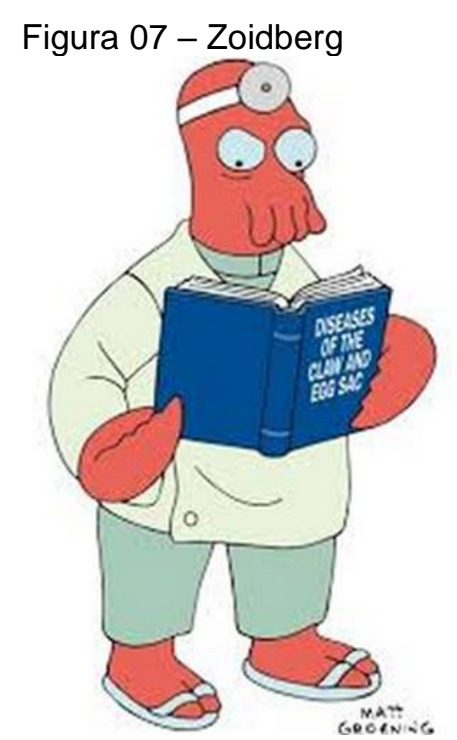

Fonte: site: disponível em: http://futurama.wikia.com/wiki/Zoidberg. Acesso em 28/10/2015. 
ZOIDBERG - Doutor Zoidberg é originário do planeta Decapod 10. Ele é um médico formado por correspondência e possui a fisiologia de vários animais marinhos, pois produz tinta como polvos, cria pérolas como ostras e possui garras como caranguejos. Ele é especialista em humanos, mas não possui muita experiência, fato que fica nítido em alguns episódios. Ele é muito pobre e acaba comendo lixo às vezes.

Figura 08 - Nibbler

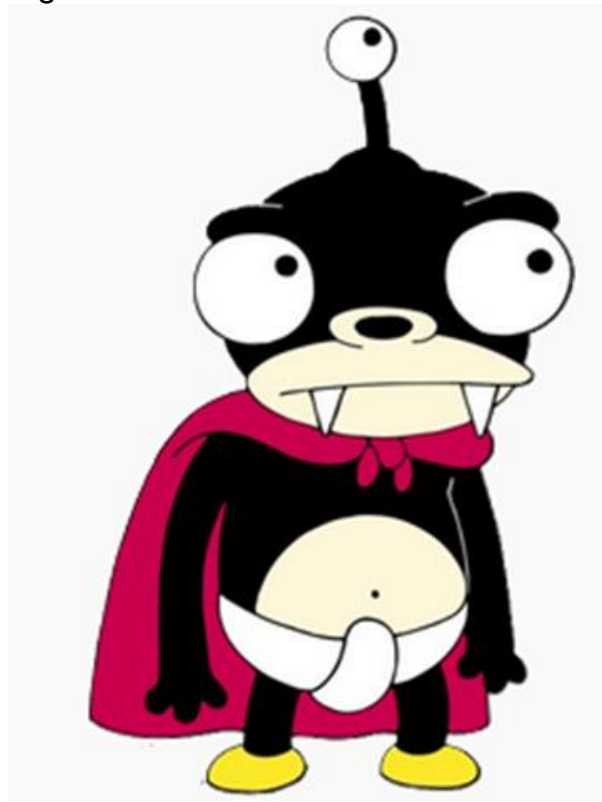

Fonte: site: disponível em: http://futurama.wikia.com/wiki/Nibbler. Acesso em 28/10/2015.

NIBBLER- Incialmente, Lord Nibbler é o animal de estimação da capitã Leela. Mas no decorrer da estória, Nibbler revela-se um ser muito inteligente, que contribuiu para que Fry caísse no tubo criogênico. Os de sua espécie possuem um apetite muito grande, e por comer demais, suas fezes compactas servem como combustível, pois formam a matéria escura. Após demostrar sua inteligência, ele torna-se parte da tripulação.

\subsection{JUSTIFICATIVA}

A escolha do tema do projeto de ensino de física com desenhos animados foi motivada pela busca de novos métodos para o ensino de conceitos introdutórios de física para alunos do $9^{\circ}$ ano do ensino fundamental. 
A procura por novos métodos se justifica pela falta de interesse e motivação dos alunos em aulas tradicionais de física, fato notado pelo autor do projeto, que vem trabalhando com esta faixa etária durante os últimos três anos.

Assim, com o objetivo de diversificar as aulas e fomentar o interesse dos alunos pelos estudos introdutórios da disciplina, o autor buscou um meio de contextualizar e trazer para os alunos exemplos que não somente demonstravam a teoria, mas também a prática de tais estudos, além de serem lúdicos.

O primeiro meio utilizado pelo autor foi o desenho animado Cavaleiros do Zodíaco, no qual o conceito de "zero absoluto" é explicado durante o episódio 67 intitulado Adeus ao Meu Mestre e aos Meus Amigos. A resposta dos alunos a este diferente meio se mostrou positiva, pois após sua introdução, os alunos demonstraram maior interesse na aula e solicitaram que mais desenhos fossem utilizados para ilustrar conceitos físicos.

Assim, ao buscar desenhos animados para exemplificar os conceitos físicos, o autor se deparou com algumas possibilidades: Meu Malvado Favorito, no qual estão presentes conceitos como gravitação, radiação, vetores e astronomia; Os Simpsons, em que o tema astronomia é trabalhado através do personagem de Bart Simpson que começa a gostar de estudar quando descobre um cometa; O Rei Leão, no qual também são apresentados conceitos de astronomia e Futurama, pois devido ao seu caráter futurístico, há uma maior gama de temas a serem abordados nas quais se pode ilustrar nas aulas de física conceitos como campo gravitacional, inércia, magnetismo, atrito, pressão, viagem no tempo, óptica, ondas, cinemática, entre outros.

Dentre estes conceitos, o autor decidiu focalizar no conceito de inércia para realizar sua pesquisa, pois a primeira lei de Newton fundamenta todo o estudo da Dinâmica, campo da física estudado pelos alunos do $9^{\circ}$ ano do ensino fundamental e sujeitos de seu projeto. 


\subsection{AMPARO LEGAL DA PESQUISA}

A Constituição Federal do Brasil de 1988 estabelece no artigo 5º, incisos XXII, XXIII e XXVII a garantia do direito à propriedade, a função social da propriedade e o direito exclusivo dos autores sobre suas obras.

A lei 9610 de 1998 regula os direitos autorais no Brasil e estabelece normas para a utilização, publicação e reprodução de obras. O capítulo IV trata das limitações dos direitos autorais e o artigo 46 e seus incisos das permissões legais para o uso por terceiros de obras protegidas, independentemente da vontade do criador ou do titular. A lei permite a reprodução de trechos de qualquer obra, desde que indicado o nome do autor e a origem da obra, bem como a apresentação sem intuito de lucro e com fins exclusivamente didáticos em estabelecimentos de ensino.

A legislação permite o uso do desenho animado Futurama como ferramenta de ensino sem que houvesse ofensa aos direitos autorais. Apesar de ser um seriado da FOX dos Estados Unidos da América, o desenho animado é licenciado, comercializado e exibido no Brasil e está, portanto, sujeito à legislação brasileira. As dúvidas sobre os aspectos legais que surgiram durante o desenvolvimento do trabalho foram sanadas com o auxílio de um advogado.

O cerne da presente pesquisa científica é a abordagem lúdica do conceito de inércia que desperte maior interesse por parte do aluno e consequentemente promova uma aprendizagem significativa. O projeto do trabalho foi desenvolvido em um colégio do sistema privado de ensino do Distrito Federal. Foram exibidos trechos de oito episódios aos estudantes, com o intuito de os alunos perceberem (visualizarem) o conceito de inércia. As exibições foram realizadas durante as aulas, gratuitamente, com a finalidade apenas de estudo.

Os dados analisados permitem concluir que com a utilização do desenho animado Futurama como ferramenta de ensino não houve prejuízo aos detentores dos direitos autorais, nem aos legítimos interesses dos autores, pois na verdade aumentou o interesse dos estudantes em conhecer mais a respeito do seriado. $\mathrm{O}$ presente trabalho atende aos conceitos das normas estabelecidas na lei dos direitos autorais, no que concerne a direitos autorais, e a exibição do desenho animado a 
estudantes contempla a função social da propriedade presente na Constituição Federal de 1988.

\subsection{METODOLOGIA DA APLICAÇÃO DO PRODUTO}

Para a aplicação do produto, foram selecionados como sujeitos 53 alunos do 9o ano do ensino fundamental com idade entre 13 e 15 anos. Os alunos estavam divididos em dois grupos que correspondem a duas turmas distintas. O produto foi aplicado em uma escola da rede particular de ensino fundamental e médio localizada na região administrativa de Brasília - Asa Sul; que foi escolhida por possuir a melhor infraestrutura dentre as quais o autor da pesquisa trabalha.

O produto foi aplicado com a apresentação aos estudantes de oito trechos, de oito episódios distintos do desenho animado. Em cada trecho, o conceito de inércia é abordado em um contexto diferente e uma discussão com os alunos é feita de modo a fazer um levantamento de subsunçor deles, assim como analisar os conhecimentos prévios dos alunos sobre o tema inércia. A exibição dos episódios torna-se importante, pois é uma forma de aproximar os estudantes de algumas situações, deixando-os motivados como Ausubel sugere, e trabalhando na perspectiva de Vygotsky ao levar em consideração o contexto sócio-históricocultural. Os subsunçores necessários para a compreensão do conceito de inércia são velocidade, aceleração e referenciais, e movimento relativo ${ }^{6}$.

A seguir são apresentados os trechos utilizados no produto para ilustrar o conceito de inércia como são apresentados na cartilha do professor. É apresentado primeiramente a temporada, depois o número do episódio, com uma sinopse juntamente com o intervalo de tempo utilizado, sinopse física elaborada pelo autor e

\footnotetext{
6 Exemplo 1:
}

a) Subsunçor = um corpo pode estar em movimento para um dado referencial ou em movimento para outro.

b) Conteúdo potencialmente significativo = para um corpo parar ele precisa ser desacelerado através de uma força aplicada no sentido oposto do movimento.

c) Estrutura cognitiva modificada (subsunçor alterado) = um corpo em movimento para um dado referencial tende a permanecer se movendo até que uma força seja impressa no sentido oposto do movimento. 
os aspectos a serem explorados na cena em questão, e as imagens para melhor visualização.

\section{$2^{\text {a }}$ Temporada.}

\section{Episódio 9 - De Onde eu vim?}

Sinopse: Leela conhece outro ciclope, Alcazar, o último sobrevivente da mesma espécie dela vivo no Universo. Ela decide morar com ele no seu planeta natal, onde é tratada como escrava. Percebendo isso, Fry começa a desconfiar que existe algo de errado com Alcazar e começa a investigar.

Intervalo de tempo utilizado: $6 \min 12 \mathrm{~s}$ a $7 \min 12 \mathrm{~s}$

Sinopse Física: Leela, Fry, Bender, Amy e Doutor Zoidberg começam a jogar online e conhecem outro ciclope. A princípio, Leela seria a única da espécie e, ao encontrar mais um ciclope, quer entrar em contato com ele, mas Fry acaba matando-o no jogo antes de eles conseguirem conversar mais. A tripulação pega um trabalho de entrega de pipocas para o planeta cineplex 14. Leela então recebe um e-mail de Alcazar, que os convida a conhecer o seu planeta. Leela, então, abre a comporta de onde está a carga e faz uma curva brusca.

Aspectos físicos a serem explorados: No Episódio é possível abordar os seguintes conceitos: inércia, atração gravitacional e propagação de calor. Quando Leela faz a curva, ela ejeta da nave uma caixa com pipoca que segue seu caminho em linha reta continuando seu movimento (inércia). Entretanto, a caixa é atraída por uma estrela (atração gravitacional) e a pipoca explode à medida que se aproxima da estrela, o que evidencia a propagação de calor por irradiação.

A seguir as imagens de 9 a 12, que auxiliam na visualização do conceito inércia. É importante que os alunos percebam tal conceito ao longo da exibição do desenho.

Figura 9 - Trecho do episódio 9 da 2 $2^{\underline{a}}$ Temporada de Futurama. 


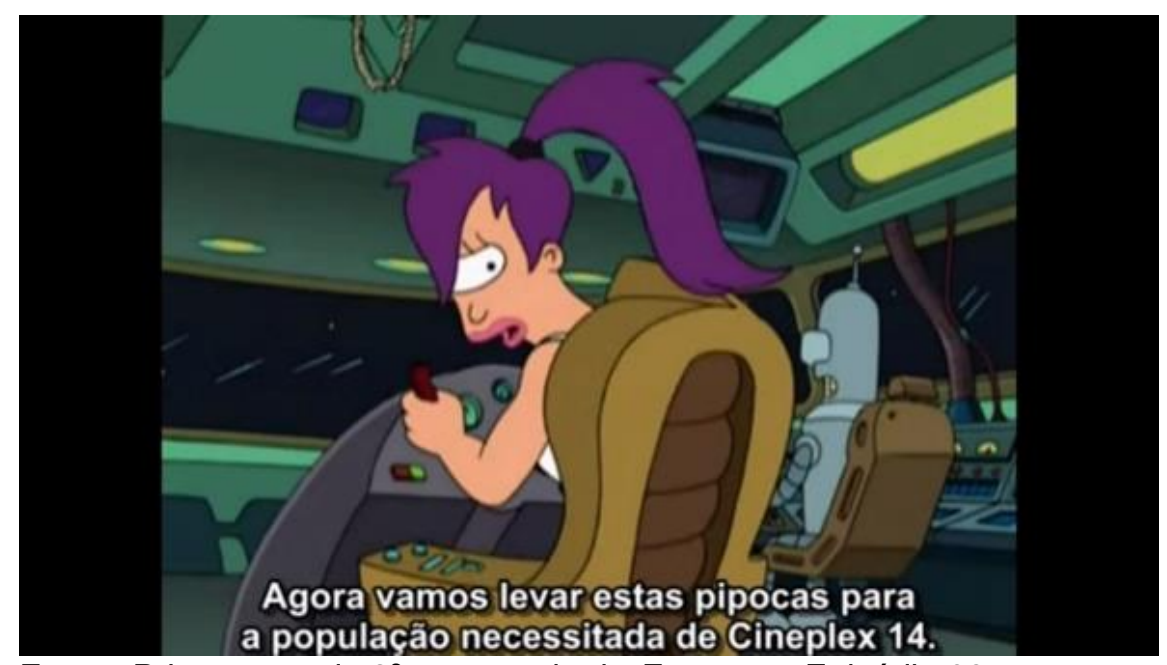

Fonte: Print screen da $2^{\underline{a}}$ temporada de Futurama, Episódio 09.

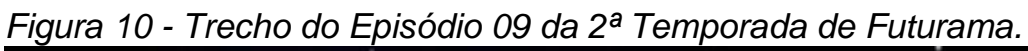

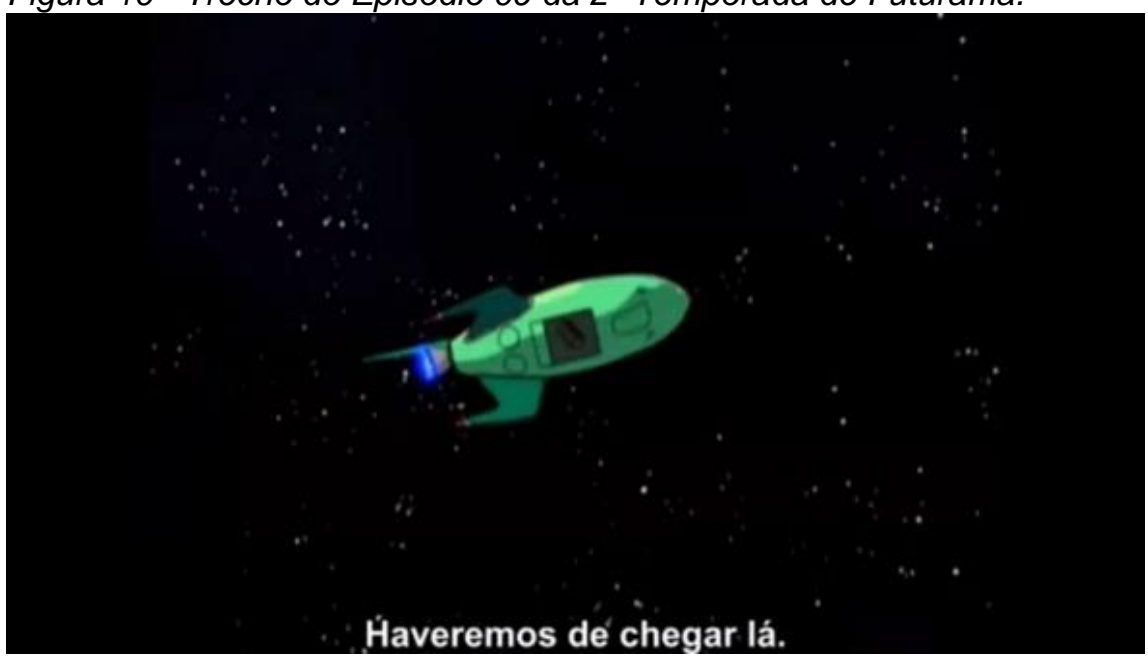

Fonte: Print screen da $2^{\mathrm{a}}$ temporada de Futurama, Episódio 09.

Figura 11 - Trecho do Episódio 09 da $2^{\mathrm{a}}$ Temporada de Futurama.

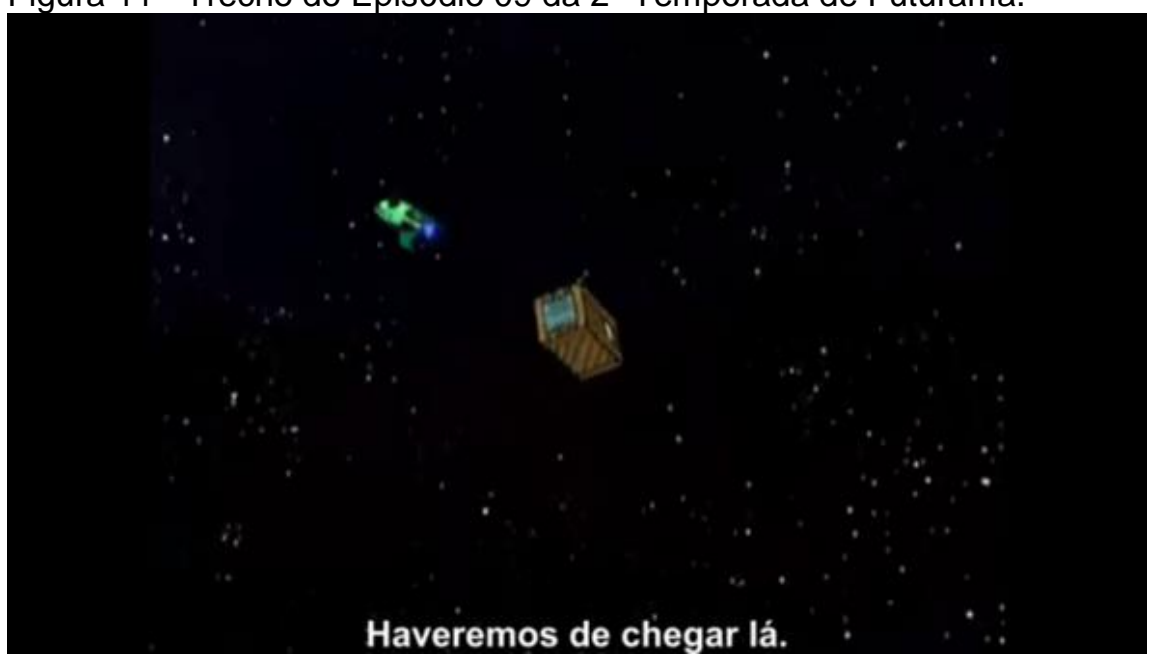

Fonte: Print screen da 2 $2^{\underline{a}}$ temporada de Futurama, Episódio 09. 
Figura 12 - Trecho do Episódio 09 da 2 $2^{\mathrm{a}}$ Temporada de Futurama.

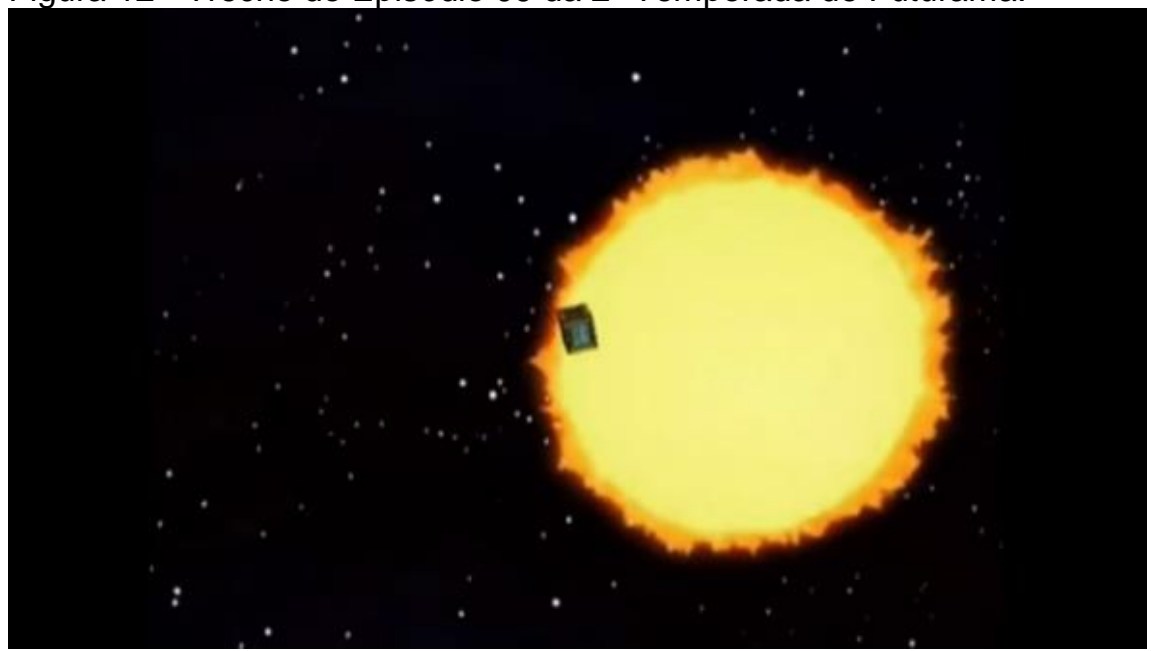

Fonte: Print screen da 2 $2^{\underline{a}}$ temporada de Futurama, Episódio 09.

2a Temporada

\section{Episódio 13 - Bender na máfia.}

Sinopse: A tripulação da planeta express não possui dinheiro para pagar um jantar. Para isso, Bender começa a trabalhar no restaurante para poder pagar a conta. Um dia quando o chefe da máfia robô chega ao restaurante e escolhe uma mesa para se sentar, Bender decide arrumar a mesa para os robôs da máfia. Dessa maneira, devido ao seu estilo, recebe convite para trabalhar na máfia.

Intervalo de tempo utilizado: $8 \mathrm{~min} 20 \mathrm{~s}$ a $9 \mathrm{~min} 10 \mathrm{~s}$

Sinopse Física: Ao arrumar uma mesa para o chefe da máfia Robô, ele puxa o pano da mesa que está cheia de utensílios e eles continuam no mesmo lugar. Entretanto, este não era o seu intuito.

Aspectos físicos a serem explorados: Inércia, pois quando Bender puxa a toalha da mesa de maneira veloz, os objetos continuam parados na parte superior da mesa. Recomenda-se uma discussão, questionando aos alunos se o resultado seria o mesmo se a toalha não fosse puxada rapidamente. Nesse instante, recomenda-se comentar sobre atrito e impulso.

A seguir, as imagens de 13 a 20 auxiliam na visualização do conceito inércia. É importante que os alunos percebam tal conceito ao longo da exibição do desenho.

Figura 13 - Trecho do Episódio 13 da 2ª Temporada de Futurama 


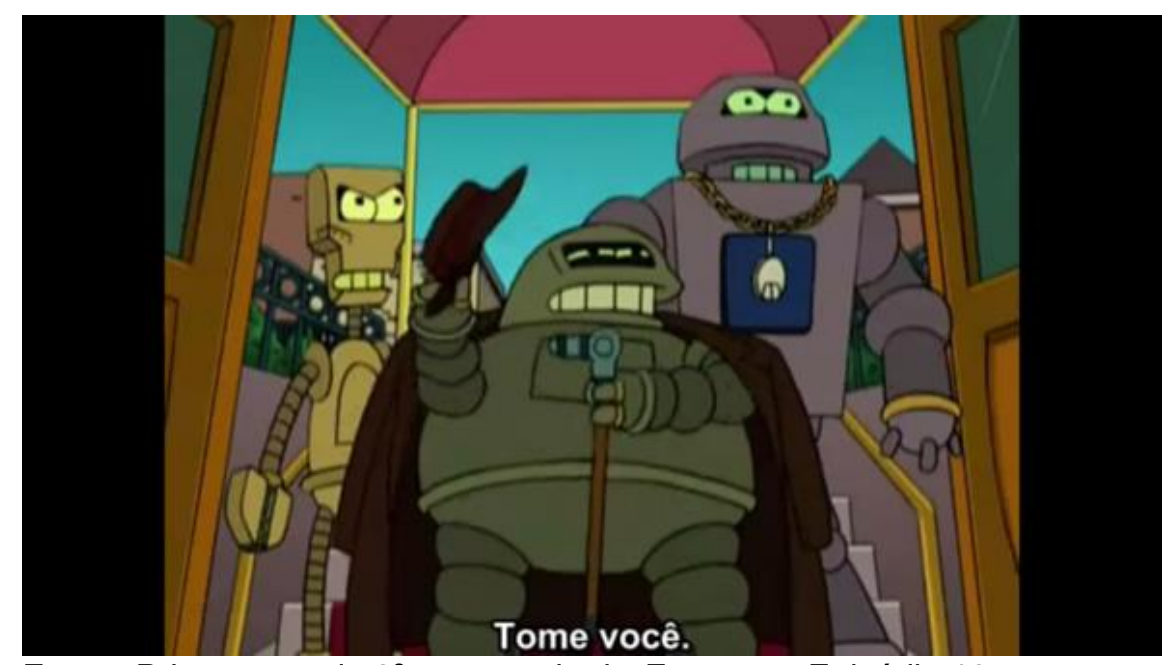

Fonte: Print screen da 2a temporada de Futurama, Episódio 13.

Figura 14 - Trecho do Episódio 13 da 2ª Temporada de Futurama

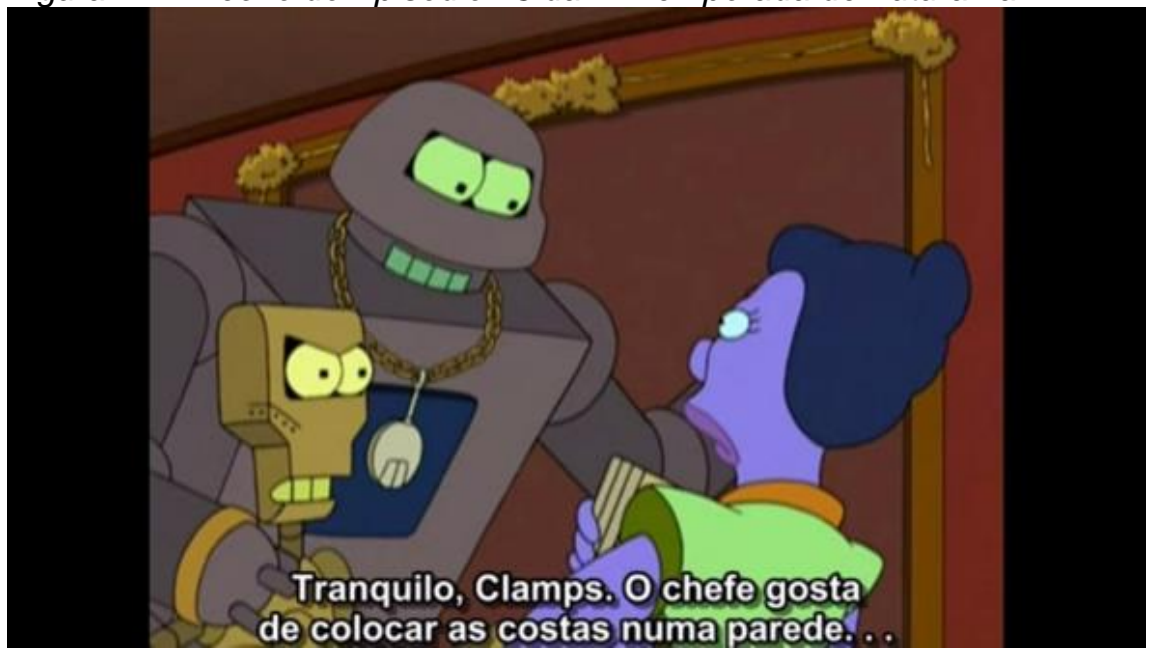

Fonte: Print screen da $2^{\mathrm{a}}$ temporada de Futurama, Episódio 13.

Figura 15 - Trecho do Episódio 13 da 2a Temporada de Futurama

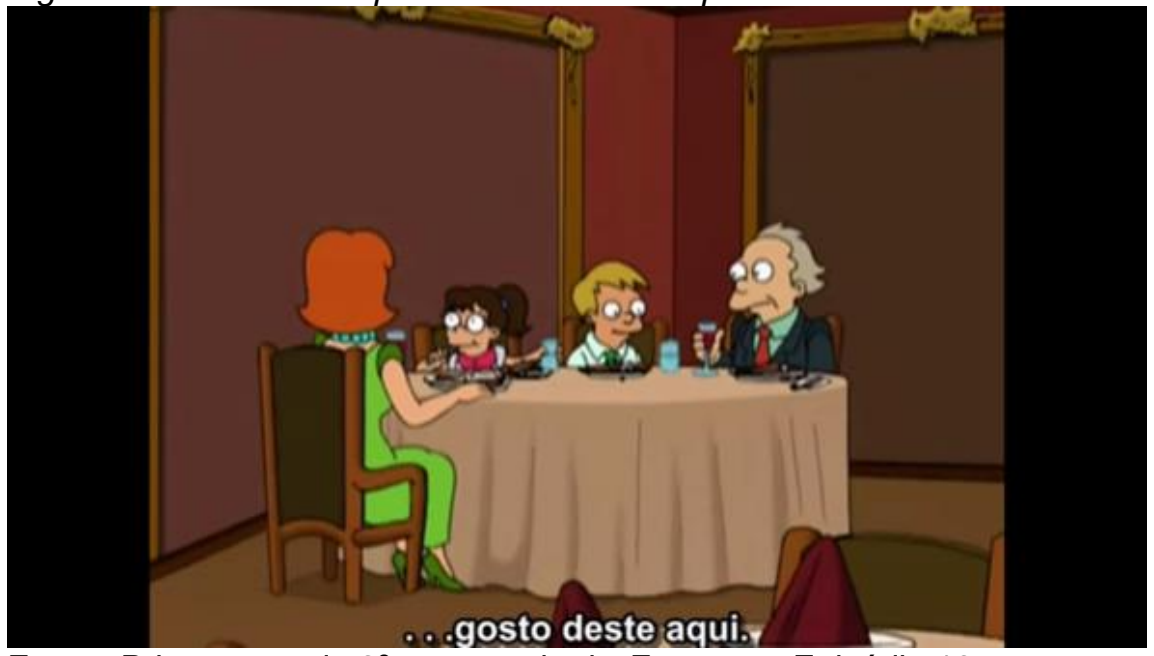

Fonte: Print screen da 2ª temporada de Futurama, Episódio 13.

Figura 16 - Trecho do Episódio 13 da 2 $2^{\underline{a}}$ Temporada de Futurama 


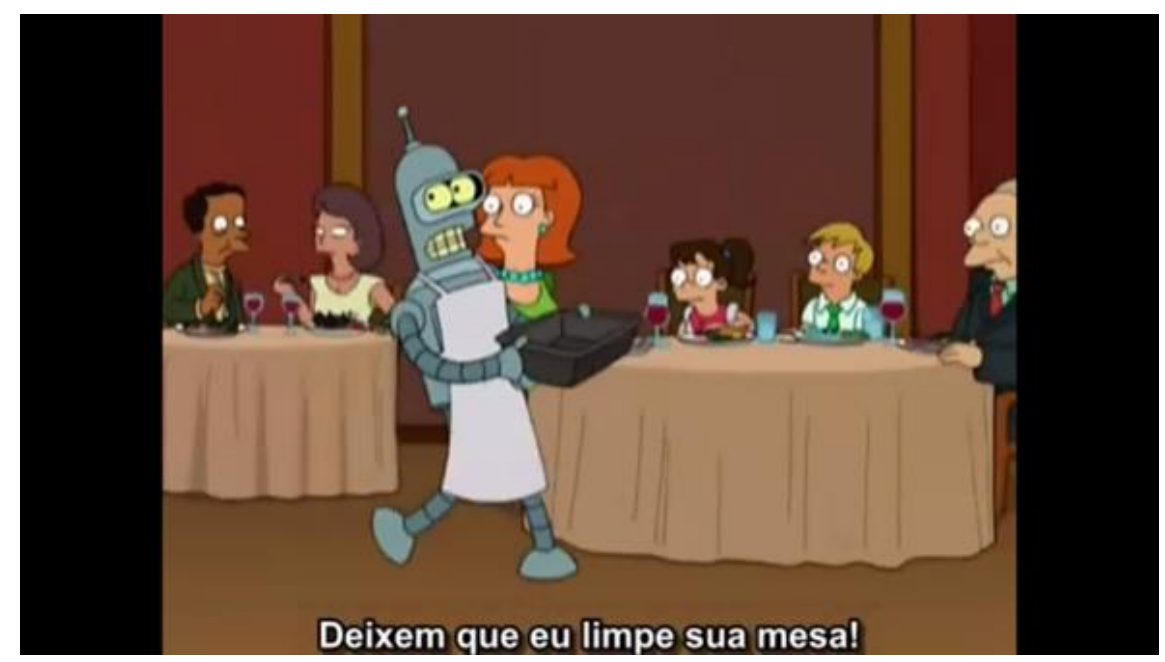

Fonte: Print screen da 2a temporada de Futurama, Episódio 13.

Figura 17 - Trecho do Episódio 13 da 2ª Temporada de Futurama

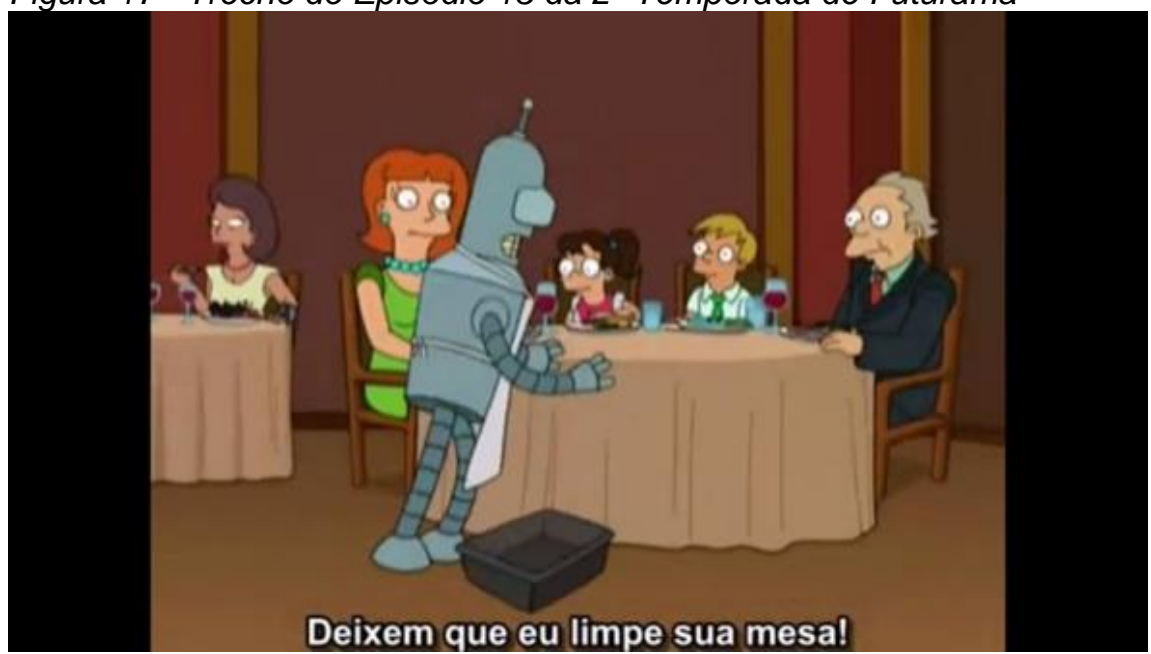

Fonte: Print screen da 2ª temporada de Futurama, Episódio 13.

Figura 18 - Trecho do Episódio 13 da 2ª Temporada de Futurama

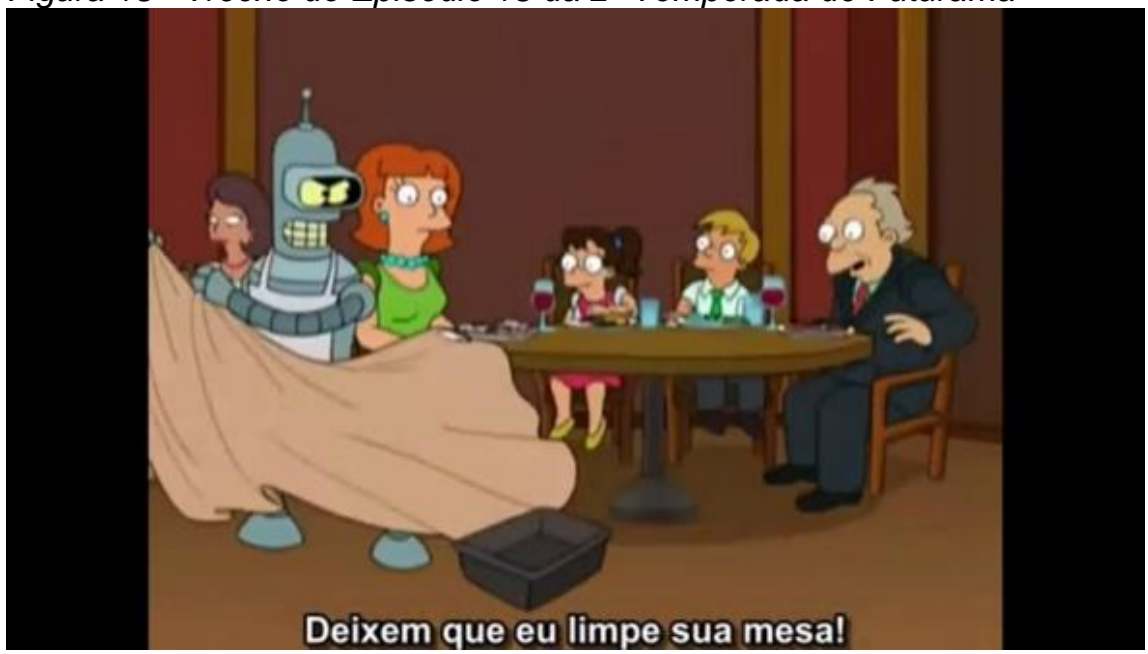

Fonte: Print screen da 2ª temporada de Futurama, Episódio 13.

Figura 19 - Trecho do Episódio 13 da 2 $2^{\underline{a}}$ Temporada de Futurama 


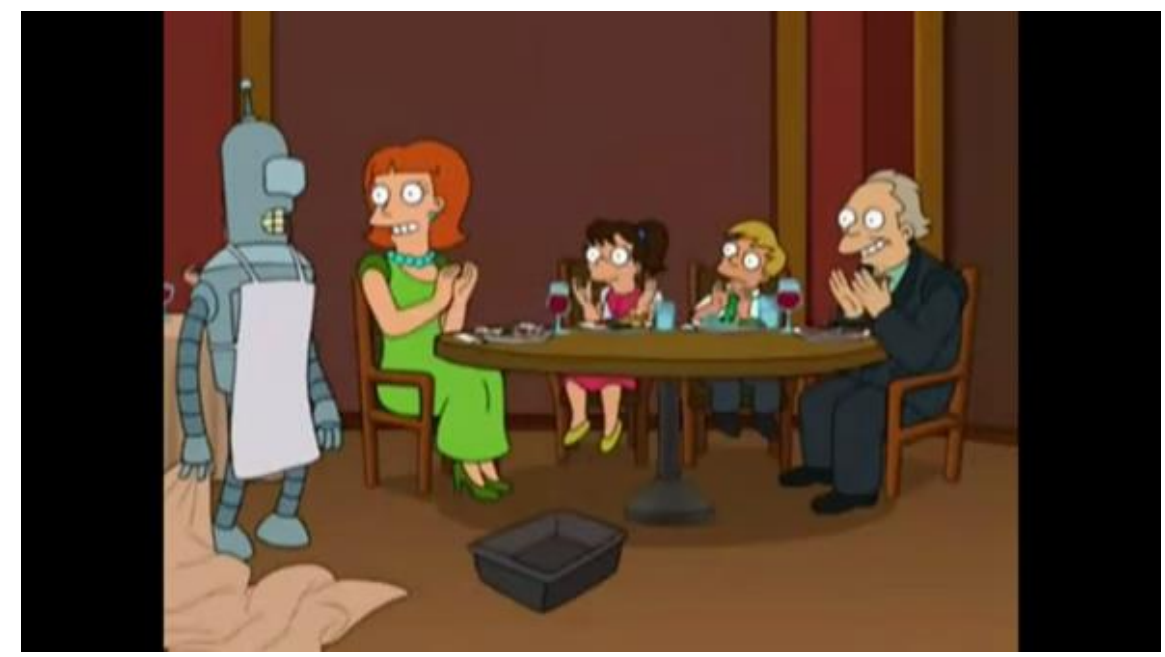

Fonte: Print screen da 2ª temporada de Futurama, Episódio 13.

Figura 20 - Trecho do Episódio 13 da 2ª Temporada de Futurama

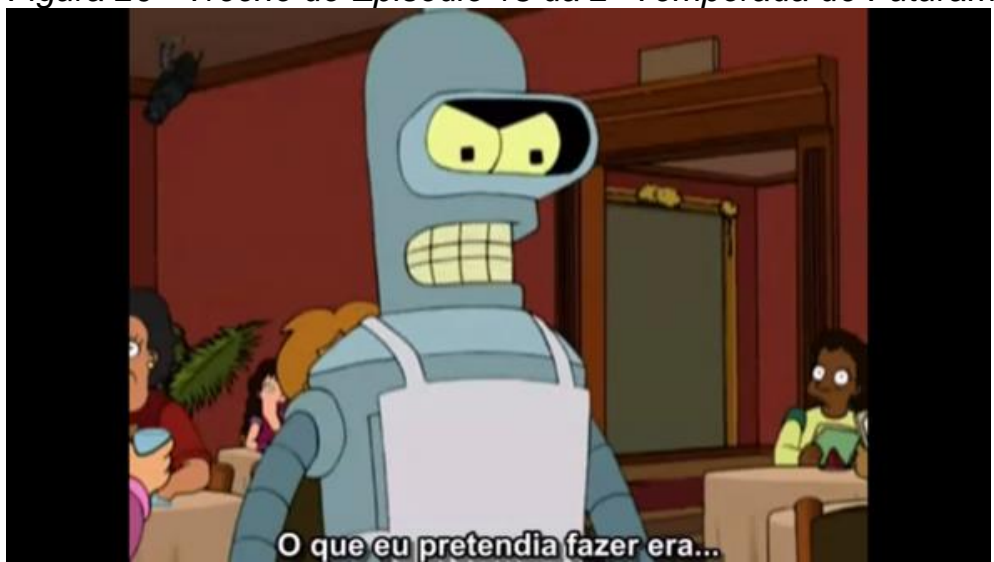

Fonte: Print screen da $2^{\mathrm{a}}$ temporada de Futurama, Episódio 13.

\section{2a Temporada}

\section{Episódio 18 - RÔBOCAR ASSASSINO}

Sinopse: Bender recebe a herança, o castelo de seu tio Vladimir. Nesse castelo ele é infectado com a maldição do Carro Antigo, o qual persegue pessoas. Cansado da matança promovida por si mesmo, Bender sai com Fry e Leela em busca do Carro Antigo original - o Projeto Satan.

Intervalo de tempo utilizado: $18 \mathrm{~min} 48 \mathrm{~s}$ a $19 \mathrm{~min} 03 \mathrm{~s}$

Sinopse Física: Leela quer quebrar um carro antigo obstruindo o escapamento, mas ao agarrar o para-choque do carro, percebe que o mesmo não possui cano de escapamento. O carro faz uma curva e Leela continua seu movimento por inércia. 
Aspectos físicos a serem explorados: Sistema de propulsão, tema que será lançado ao grupo pois tal conteúdo é trabalhado mais a frente. Inércia, quando o carro executa uma curva e Leela continua se movendo em linha reta, após tentar sabotar o carro. Velocidade relativa, uma vez que Fry foge do carro por um momento para não ser atropelado.

A seguir as imagens de 21 a 28 auxiliam na visualização do conceito inércia, o que é importante que os estudantes percebam ao longo da exibição do desenho.

Figura 21 - Trecho do episódio 18 da 2 $2^{\underline{a}}$ Temporada de Futurama.

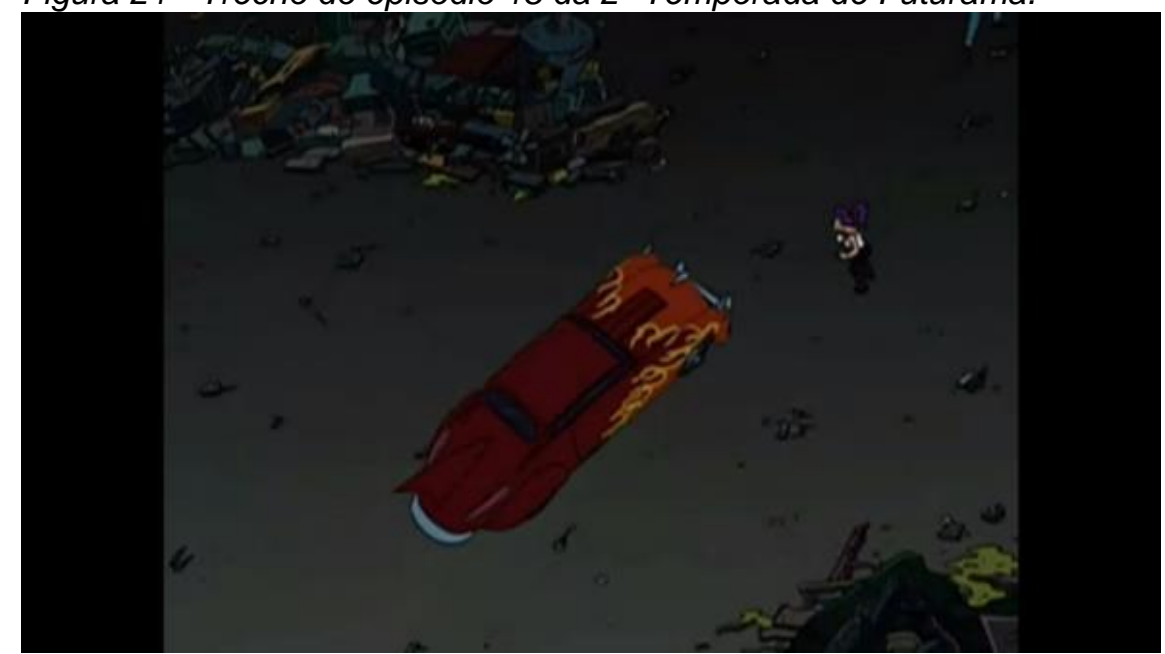

Fonte: Print screen da $2^{\mathrm{a}}$ temporada de Futurama do Episódio 18.

Figura 22 - Trecho do episódio 18 da $2^{\underline{a}}$ Temporada de Futurama.

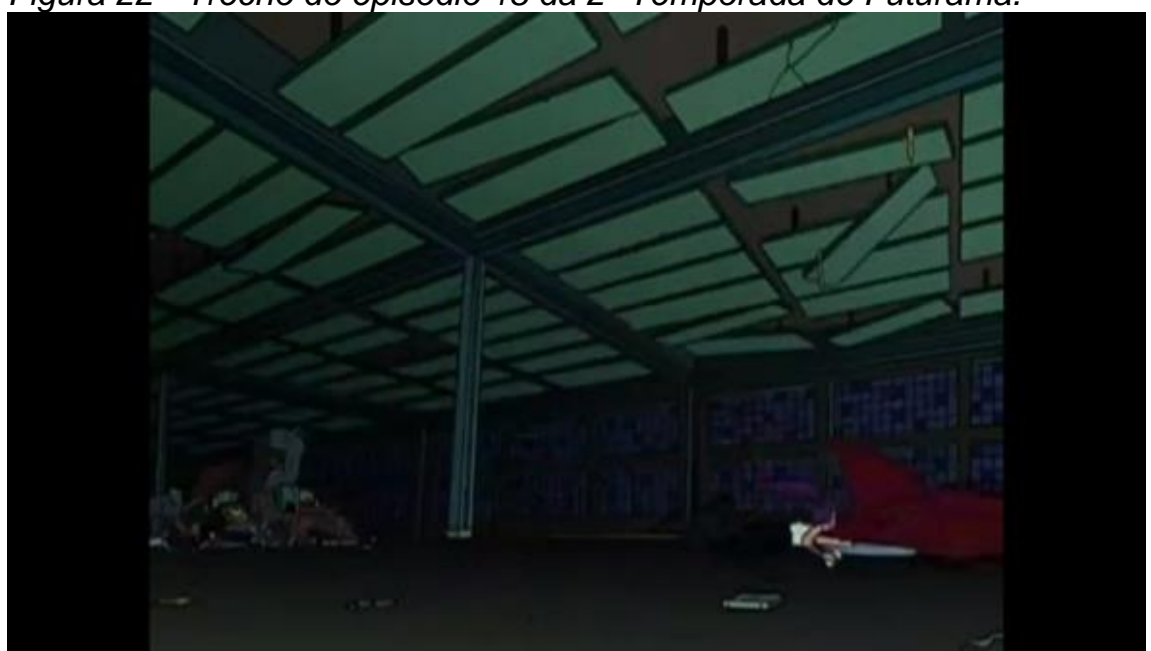

Fonte: Print screen da $2^{\mathrm{a}}$ temporada de Futurama do Episódio 18. 
Figura 23 - Trecho do episódio 18 da $2^{\underline{a}}$ Temporada de Futurama.

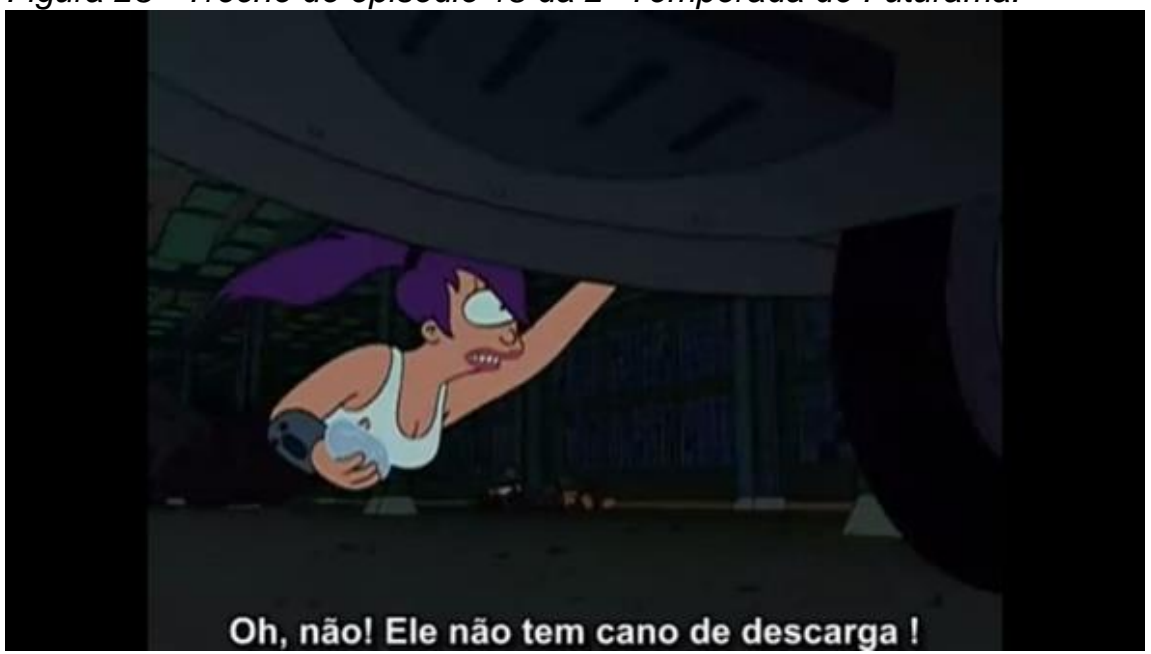

Fonte: Print screen da 2ª temporada de Futurama do Episódio 18.

Figura 24 - Trecho do episódio 18 da $2^{\text {a }}$ Temporada de Futurama.

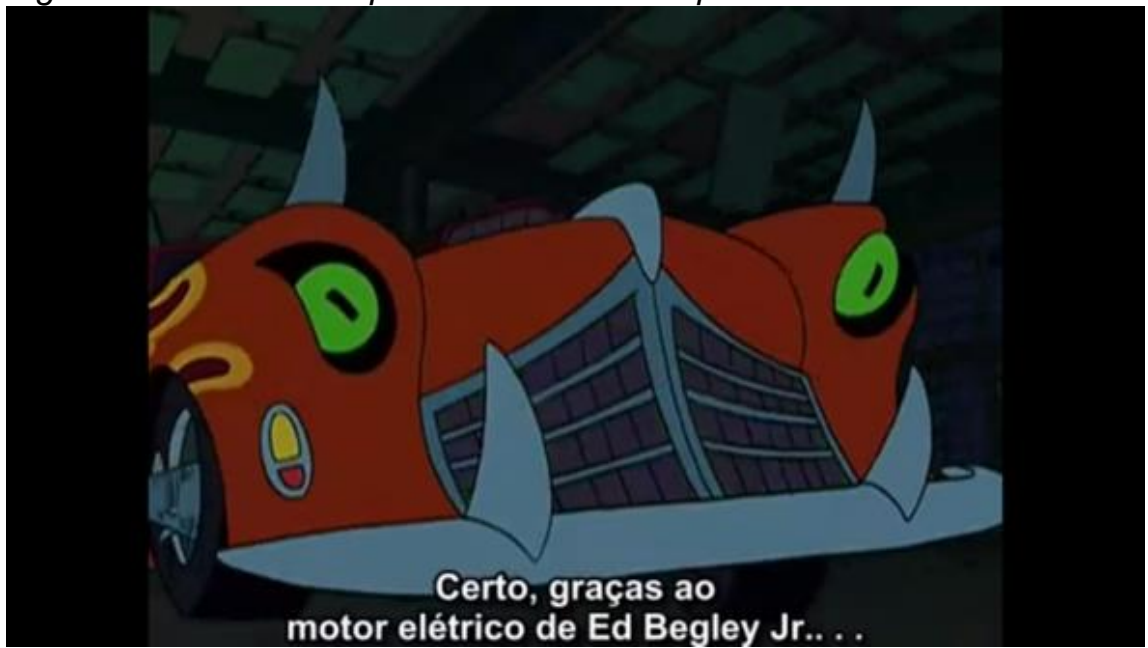

Fonte: Print screen da $2^{\mathrm{a}}$ temporada de Futurama do Episódio 18.

Figura 25 - Trecho do episódio 18 da $2^{\underline{a}}$ Temporada de Futurama.

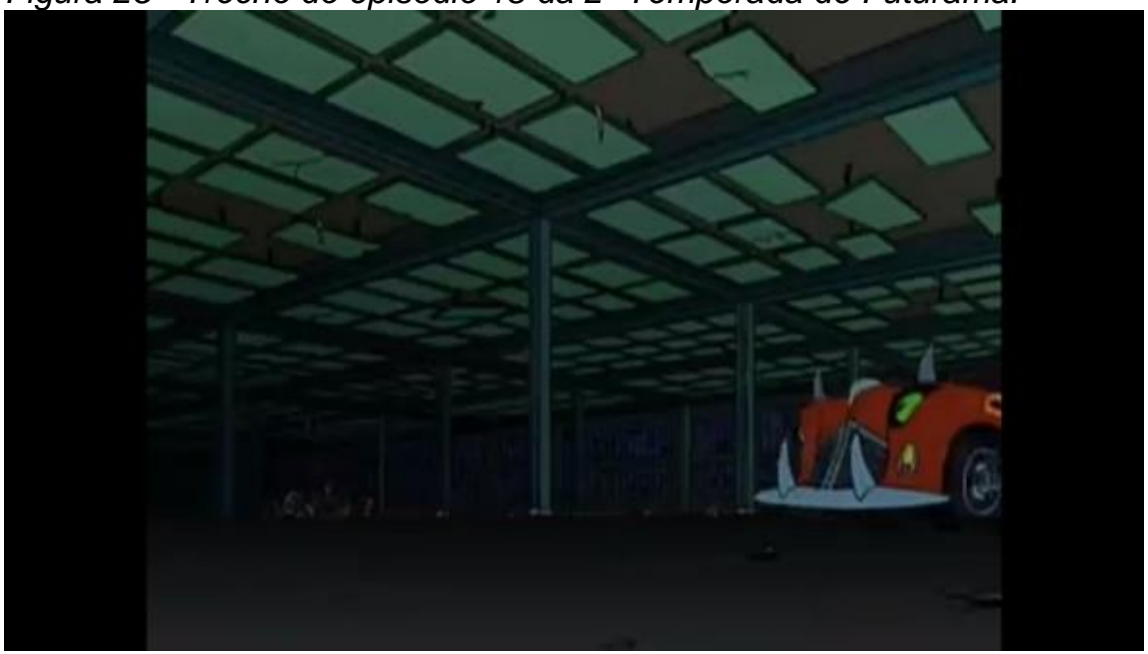

Fonte: Print screen da $2^{\mathrm{a}}$ temporada de Futurama do Episódio 18. 
Figura 26 - Trecho do episódio 18 da 2ª Temporada de Futurama.

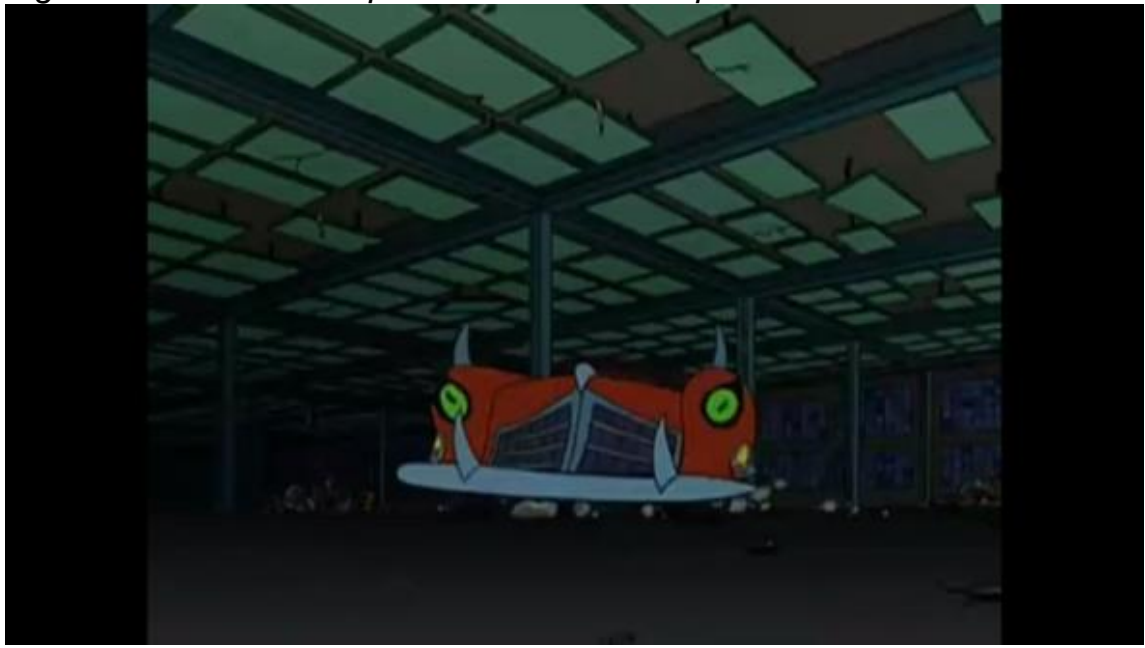

Fonte: Print screen da $2^{a}$ temporada de Futurama do Episódio 18. Figura 27 - Trecho do episódio 18 da 2 $2^{a}$ Temporada de Futurama.

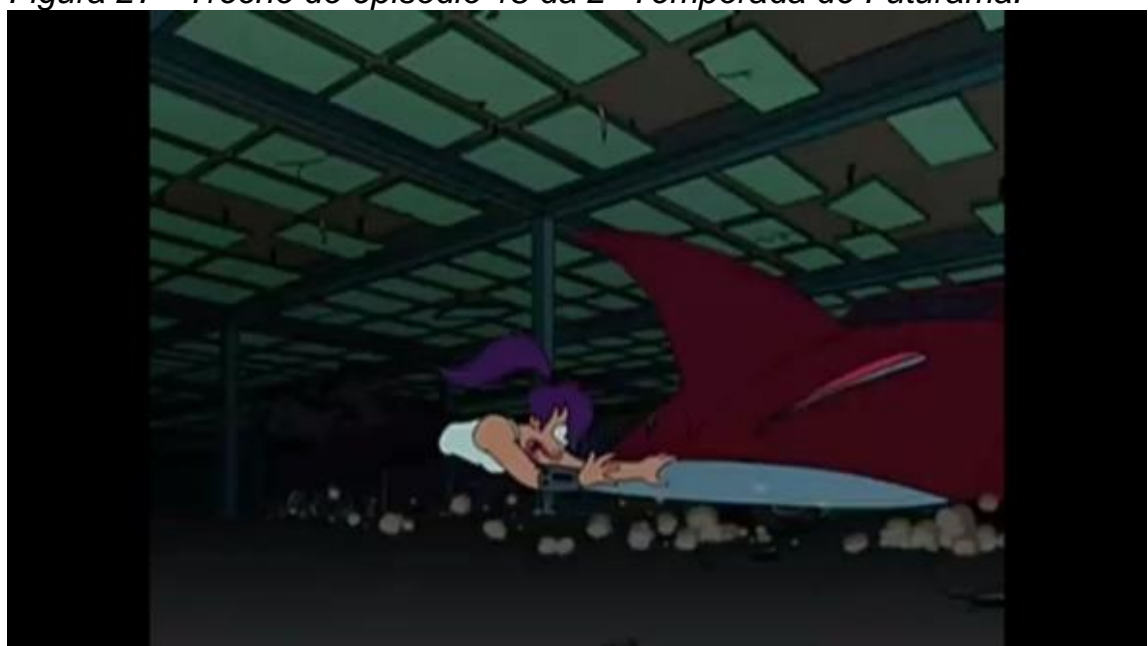

Fonte: Print screen da 2ª temporada de Futurama do Episódio 18.

Figura 28 - Trecho do episódio 18 da $2^{a}$ Temporada de Futurama.

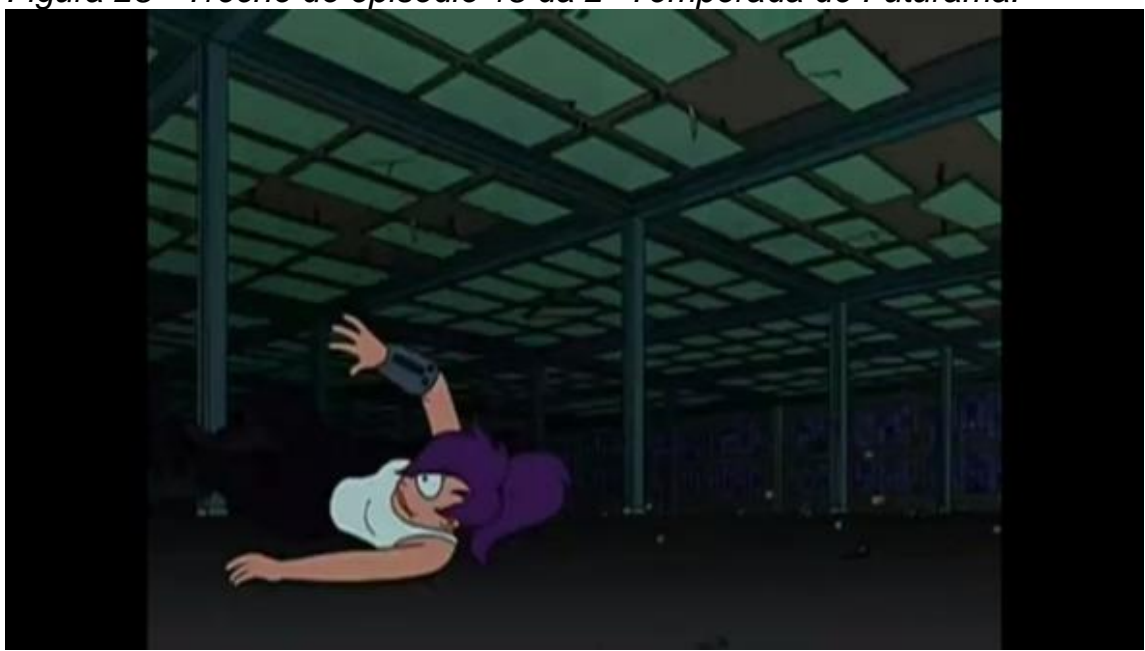

Fonte: Print screen da $2^{a}$ temporada de Futurama do Episódio 18. 


\section{3a Temporada}

\section{Episódio 19 - De volta ao passado.}

Sinopse: A explosão de uma supernova combinada com a radiação vinda de um micro-ondas onde Fry havia colocado metal leva a tripulação de volta a 1947. Na base militar de Roswell, Bender é confundido com os destroços de um OVNI, o Dr. Zoidberg vai para a sala de autópsias e Fry, sem querer, mata o seu avô Enos.

Intervalo de tempo utilizado: $2 \mathrm{~min} 00 \mathrm{~s}$ a $3 \mathrm{~min} 25 \mathrm{~s}$

Sinopse Física: Após voltarem ao passado, a nave espacial acaba por ter uma pane elétrica e logo eles caem se aproximando da terra. Durante a queda, Leela pede a todos que coloquem o cinto de segurança, pois estão em rota de colisão. Entretanto, Bender afirma que "Isso acaba com mais vidas do que salva" e se recusa a colocar o cinto. Ao colidirem, Bender continua seu movimento por inércia e atravessa o para-brisa da nave.

Aspectos a serem explorados: Queda livre, pois a nave caiu do espaço até a superfície do planeta. Ondas, pois a nave perde contato do GPS (Global Positioning System ou guia de posicionamento global). Inércia, pois durante a conversa entre Bender e Leela, antes da parada brusca da nave, a capitã manda todos colocarem o cinto de segurança e como Bender não a obedece, ele é arremessado através do para-brisa da nave. Momento importante de ressaltar a importância da ciência para a vida das pessoas.

A seguir, as imagens de 29 a 33 auxiliam na visualização do conceito de inércia. É importante que os alunos percebam tal conceito ao longo da exibição do desenho ante que os estudantes percebam ao longo da exibição do desenho.

Figura 29 - Trecho do Episódio 19 da 3ํㅜ Temporada de Futurama. 


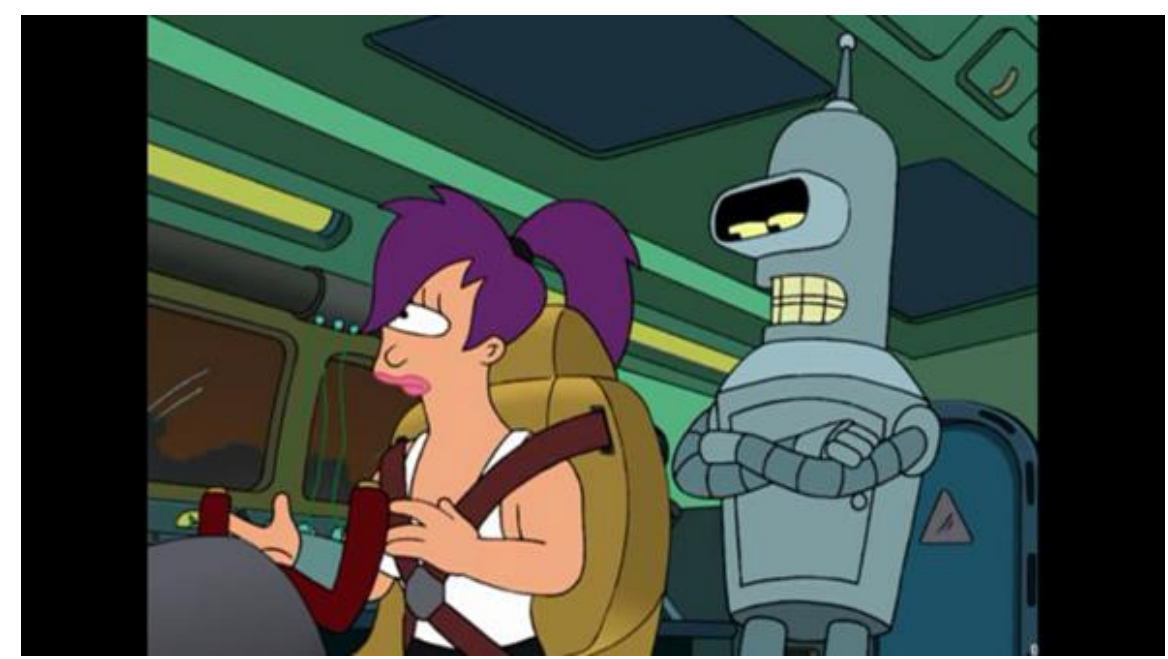

Fonte: Print screen da $3^{\underline{a}}$ temporada de Futurama do Episódio 19.

Figura 30 - Trecho do Episódio 19 da 3ª Temporada de Futurama.

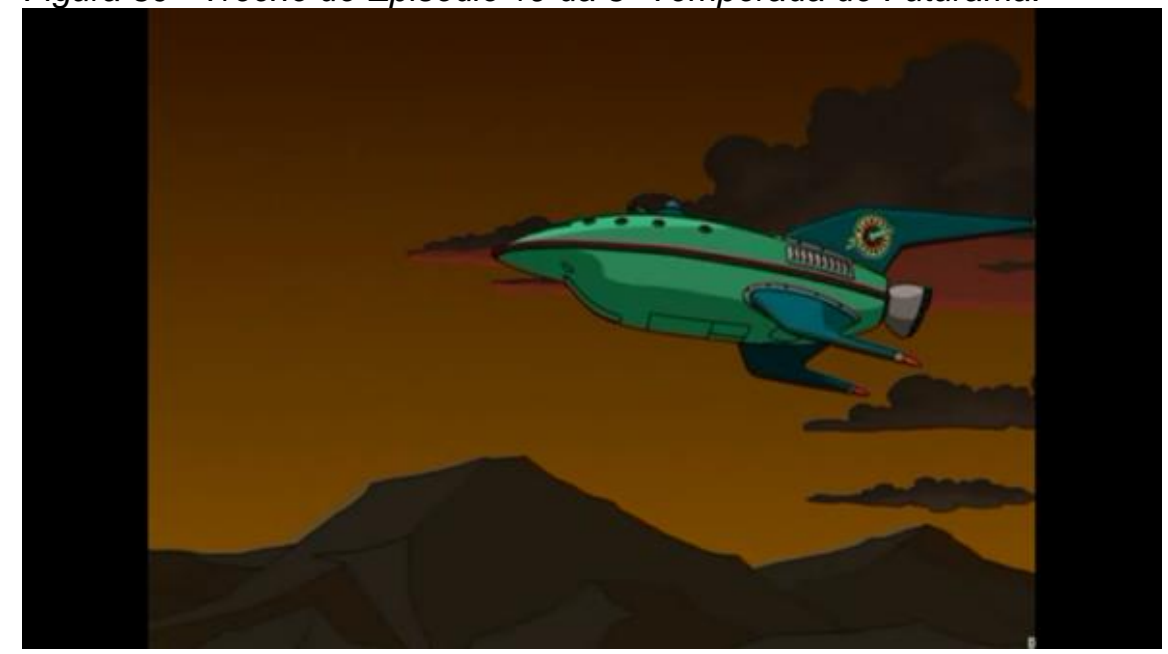

Fonte: Print screen da 3ª temporada de Futurama do Episódio 19.

Figura 31 - Trecho do Episódio 19 da 3를 Temporada de Futurama. 


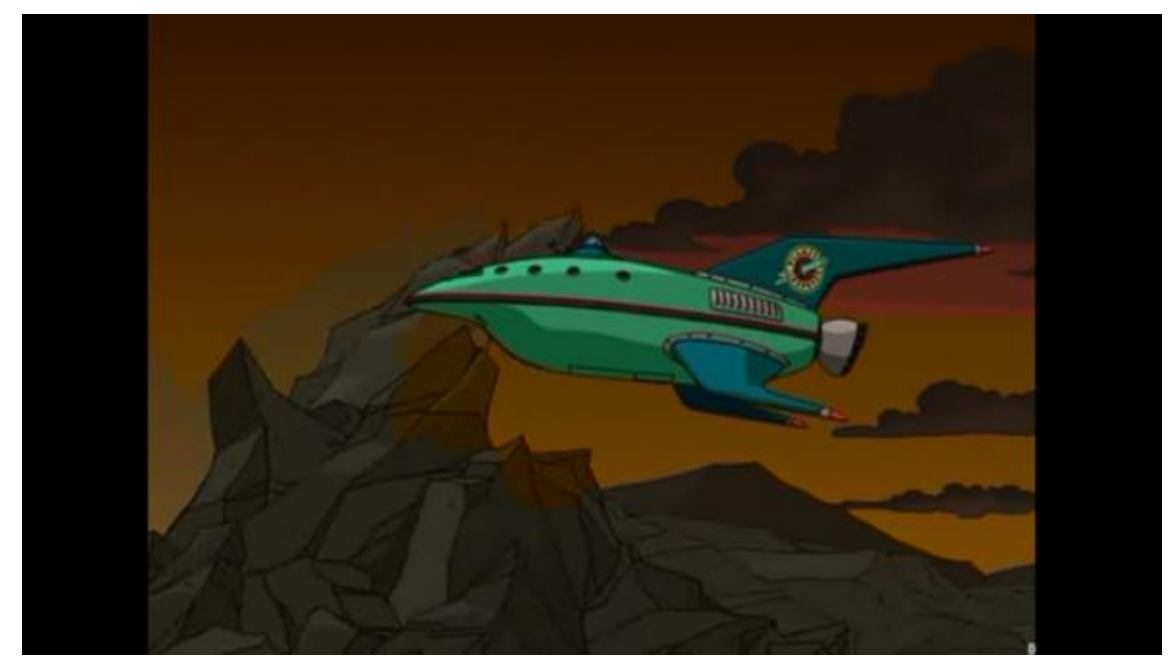

Fonte: Print screen da 3롤 temporada de Futurama do Episódio 19.

Figura 32 - Trecho do Episódio 19 da 3ª Temporada de Futurama.

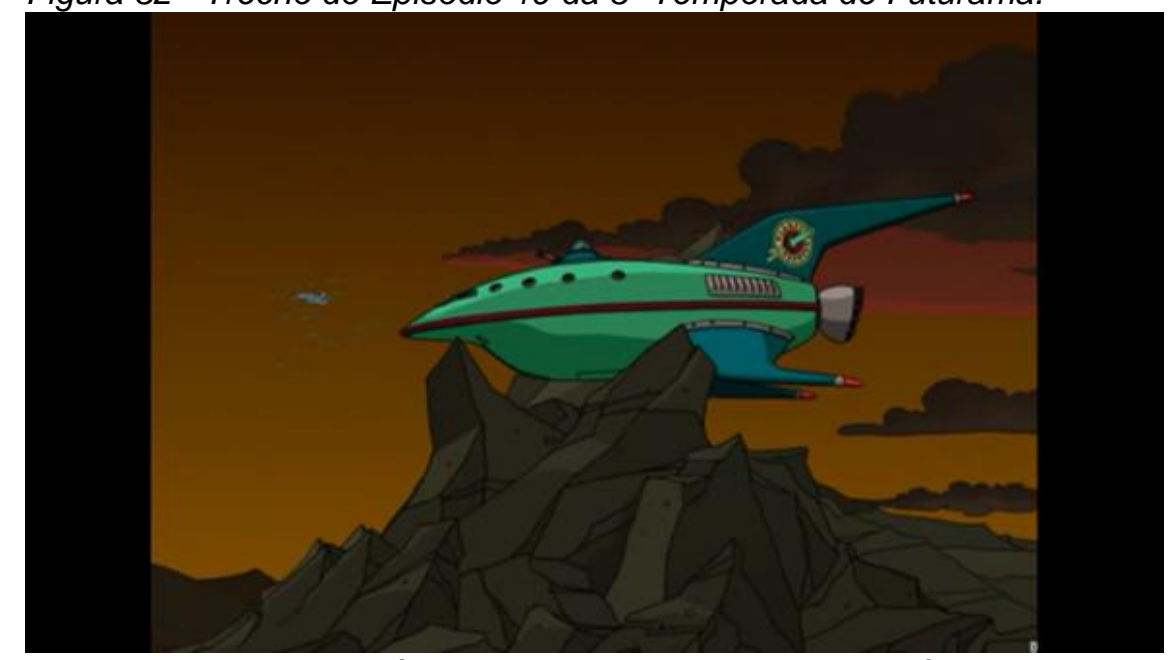

Fonte: Print screen da $3^{\text {a }}$ temporada de Futurama do Episódio 19.

Figura 33 - Trecho do Episódio 19 da 3르 Temporada de Futurama.

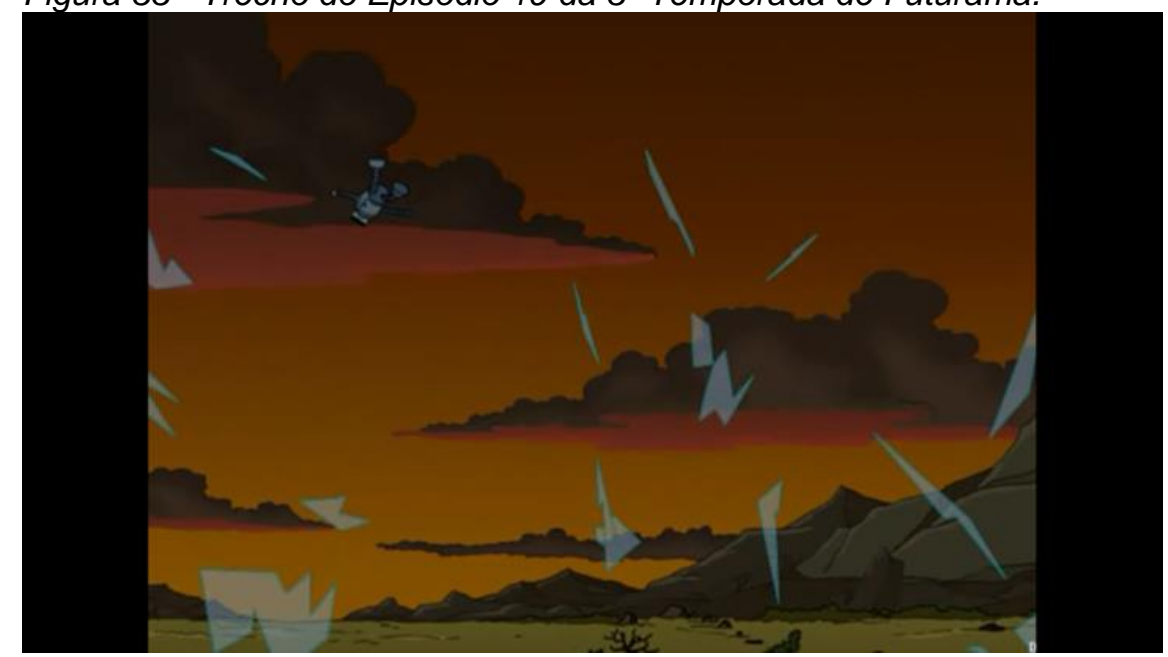

Fonte: Print screen da 3ª temporada de Futurama do Episódio 19. 


\section{Temporada}

\section{Episódio 5 - A fera com 1 bilhão de costas (parte 1)}

Sinopse: Quando um rasgo misterioso aparece no universo, visível da terra o professor Farnsworth organiza uma expedição para descobrir o que está do outro lado. Enquanto isso $\mathrm{Kif}^{7}$ e Amy estreitam relações enquanto Fry descobre que sua namorada pode estar compartilhando seu amor por aí.

Intervalo de tempo utilizado: $12 \min 40$ s a $13 \min 50$ s

Sinopse Física: O doutor Farnsworth (Tio de Fry) e o doutor Ogden Wernstrom (seu arquinimigo) disputam a possibilidade de estudar um rasgo no céu, e como estavam em uma discussão muito calorosa, acabam orientados pela cabeça de Stephen Hawking a disputar a bola da morte para decidirem quem receberá a licença que permite o estudo.

Aspectos a serem explorados: Nesse episódio pode-se trabalhar com os conceitos de velocidade linear e angular (no trecho em que Fry e um outro personagem estão em cima de esferas), conservação da quantidade de movimento (no trecho em que as esferas se chocam) e inércia (no trecho em Fry e outro personagem trocam de esferas após o choque). Uma parte importante de ser comentada, a qual não poderia ser realizada em questão caracteriza-se pela imagem 38, pois nesse instante, um personagem passa por dentro do outro, coisa que não é possível pois dois corpos não ocupam o mesmo lugar no espaço.

A seguir as imagens de 34 a 37 auxiliam na visualização do conceito inércia, o que é importante que os estudantes percebam ao longo da exibição do desenho.

Figura 34 - Trecho do Episódio 05 da 5ํㅜ Temporada de Futurama.

\footnotetext{
${ }^{7}$ Kif Kroker, é o quarto tenente da ordem democrática dos planeta. Kif é um anfíbio. Kif tem um relacionamento com Amy Wong desde a terceira temporada de Futurama.
} 


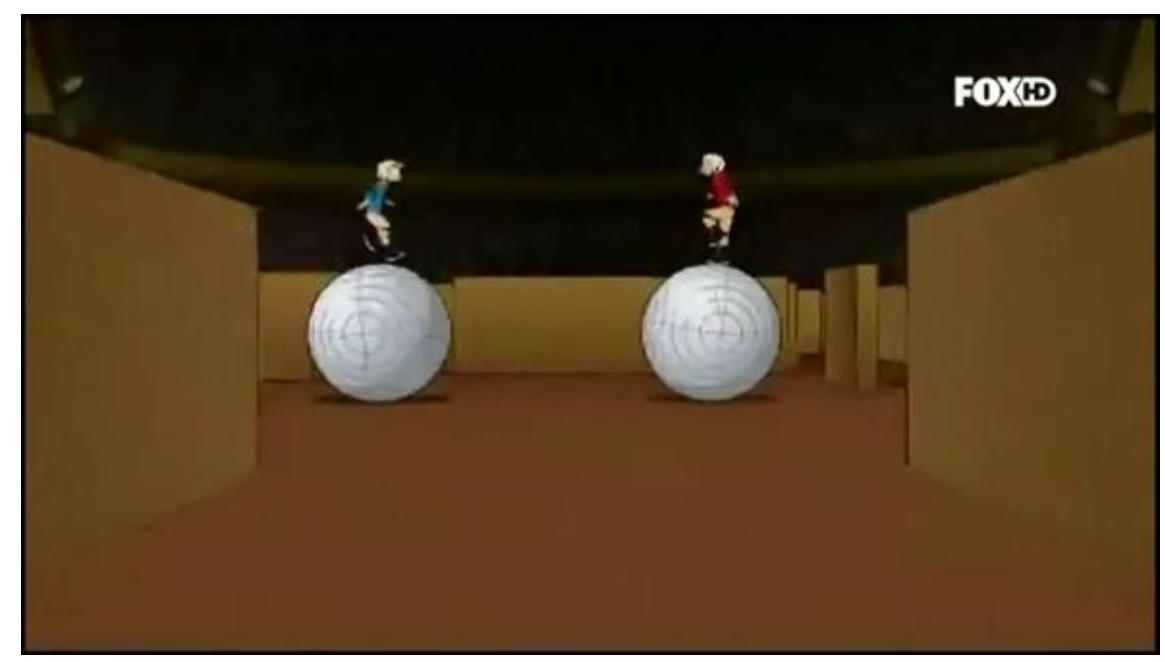

Fonte: Print screen da 5 $5^{\underline{a}}$ temporada de Futurama do Episódio 05.

Figura 35 - Trecho do Episódio 05 da 5ª Temporada de Futurama.

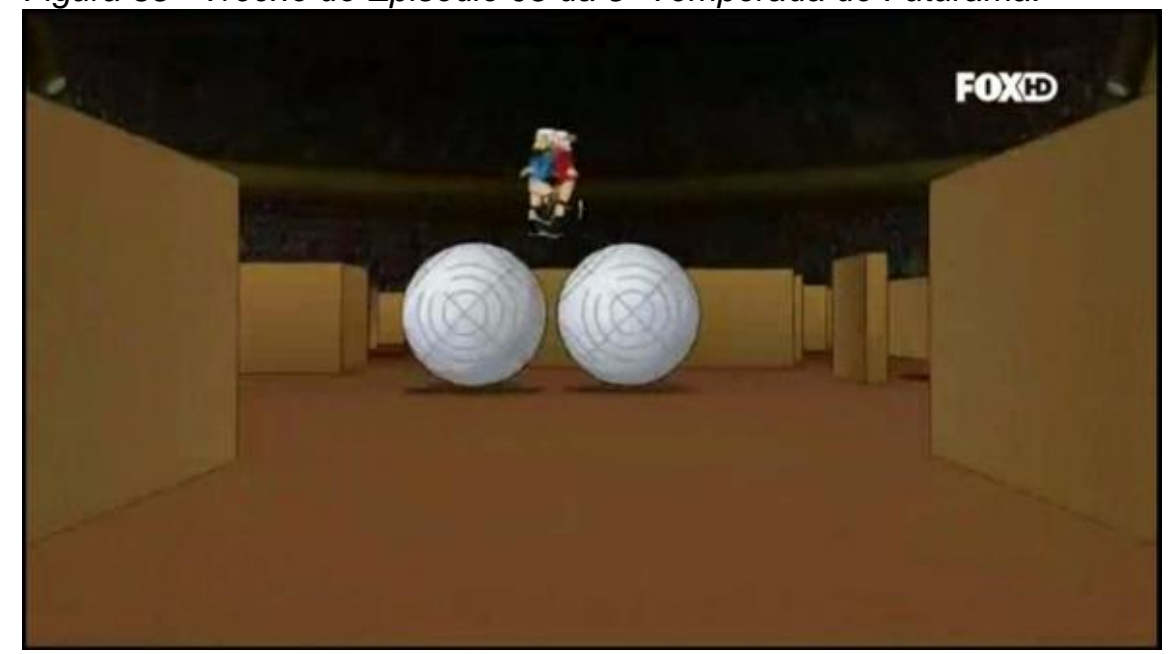

Fonte: Print screen da $5^{\mathrm{a}}$ temporada de Futurama do Episódio 05.

Figura 36 - Trecho do Episódio 05 da 5ª Temporada de Futurama. 


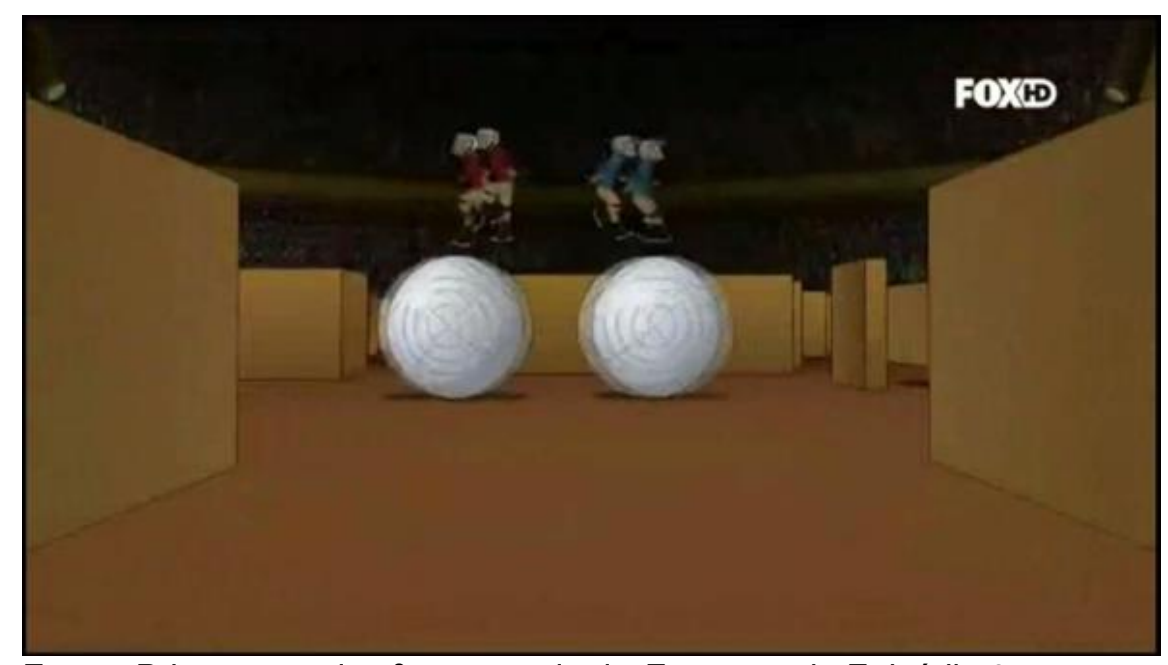

Fonte: Print screen da 5ª temporada de Futurama do Episódio 05.

Figura 37 - Trecho do Episódio 05 da 5ª Temporada de Futurama.

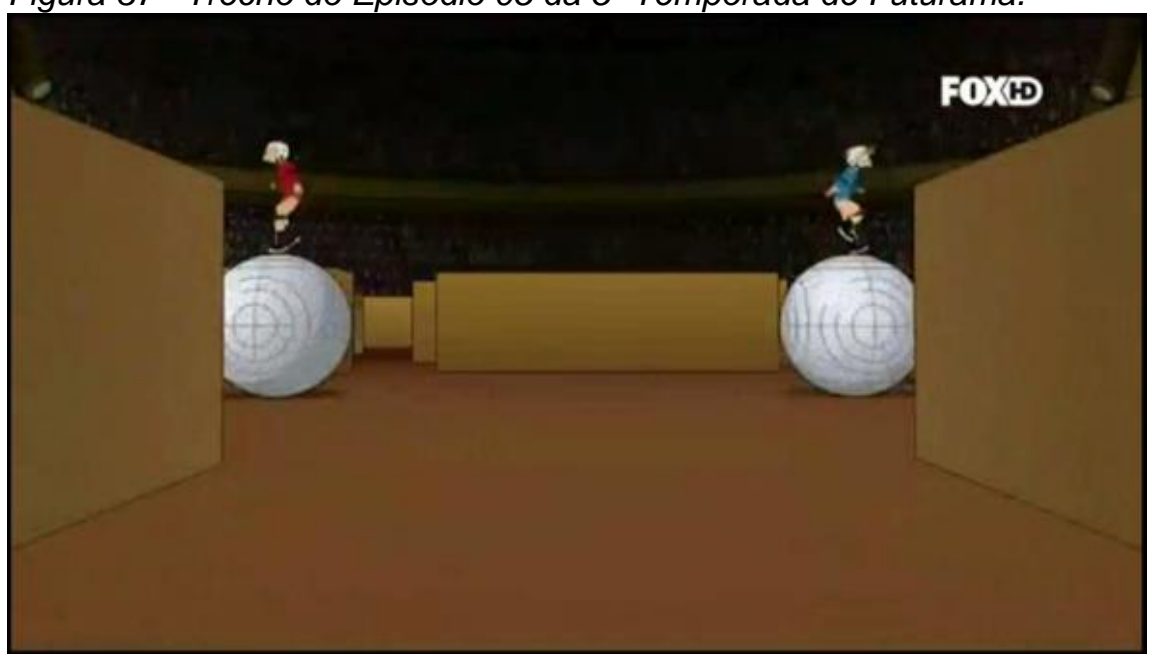

Fonte: Print screen da 5ª temporada de Futurama do Episódio 05.

\section{6a Temporada}

\section{Episódio 3 - O formulário assassino.}

Sinopse: Diversas pessoas em Nova Nova York compram a última versão do eyePhone, o qual é implantado no olho, esse dispositivo tem várias funções inclusive gravar e publicar vídeos online. Fry e Bender se desafiam para ver quem consegue mais seguidores em uma rede social.

Intervalo de tempo utilizado: 7 min 25 s a 8 min 10 s

Sinopse Física: Após o lançamento do novo eyePhone, todos os personagens principais o compram. Por ter alguns aplicativos interessantes, a capitã Turanga Leela o usa até enquanto pilota a nave espacial, fato que a leva a bater a nave. 
Infelizmente, ela estava sem cinto de segurança.

Aspectos a serem explorados: O conceito de referencial pode ser trabalhado, pois existe uma cena vista de dois locais diferentes. $O$ conceito de inércia também deve ser trabalhado, pois quando a nave se choca, a capitã Leela estava sem cinto de segurança. Logo ela continua no seu movimento, postura que colocou sua vida em risco.

A seguir as imagens de 38 a 43 auxiliam na visualização do conceito de inércia. É importante que os alunos percebam tal conceito ao longo da exibição do desenho ante que os estudantes percebam ao longo da exibição do desenho.

Figura 38 - Trecho do Episódio 03 da 6 6⿳⺈ Temporada de Futurama.

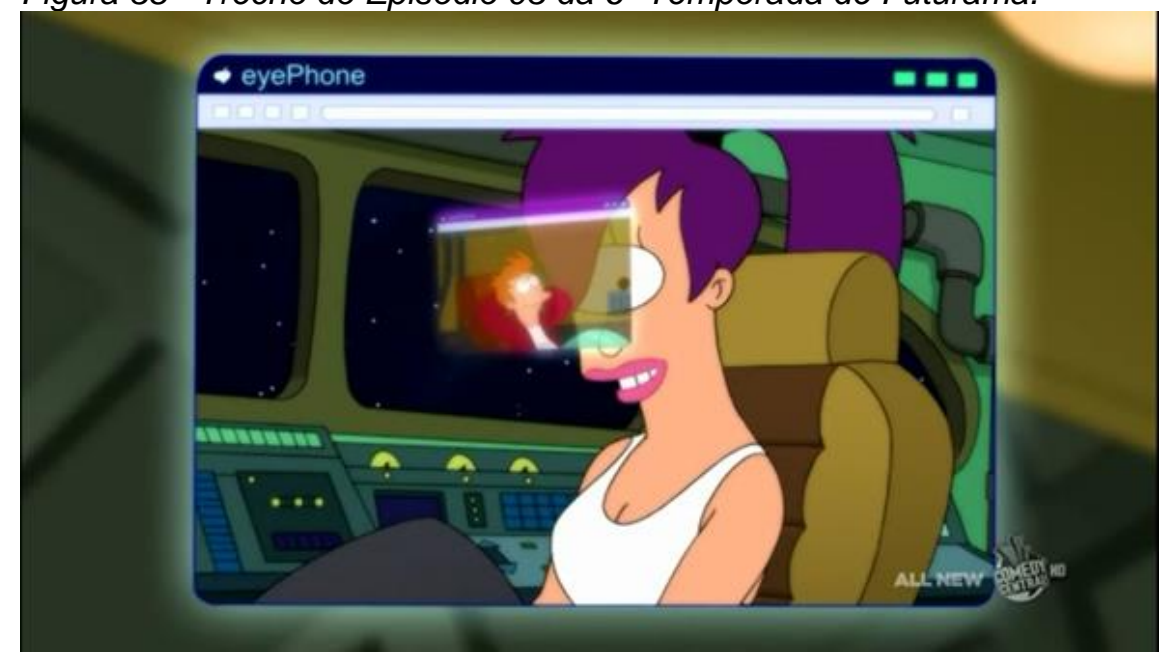

Fonte: Print screen da 6⿳亠丷厂 temporada de Futurama, Episódio 03.

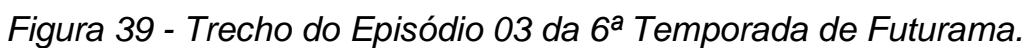

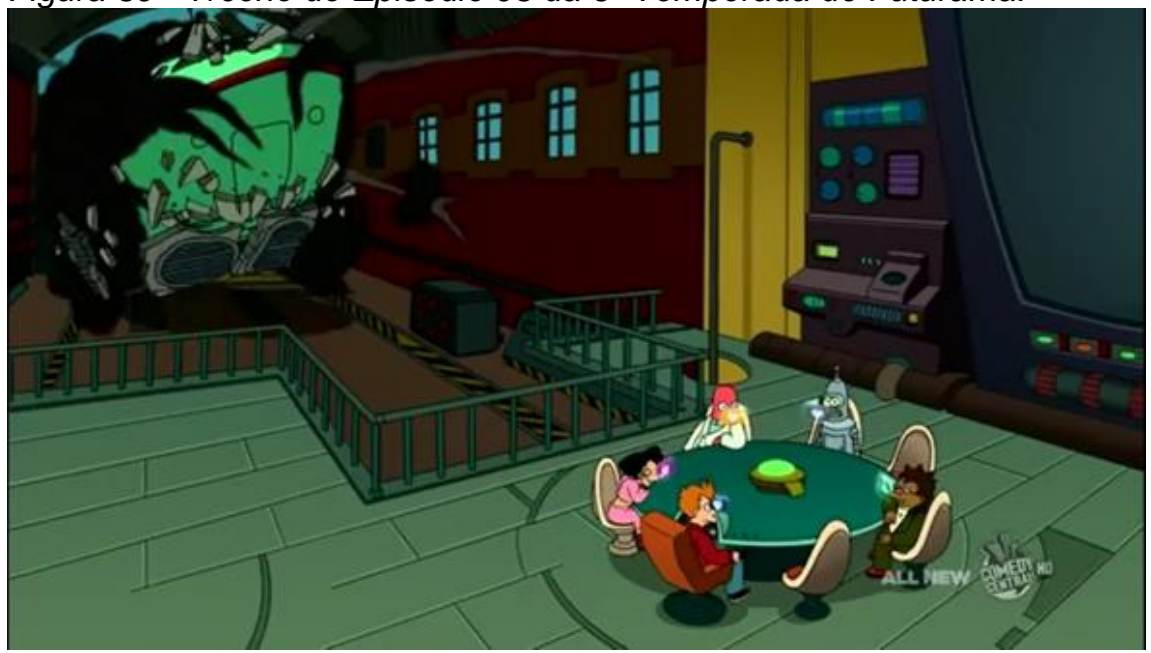

Fonte: Print screen da 6 $6^{\mathbf{a}}$ temporada de Futurama, Episódio 03.

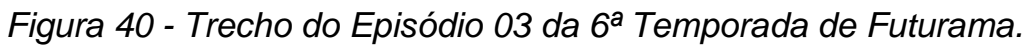




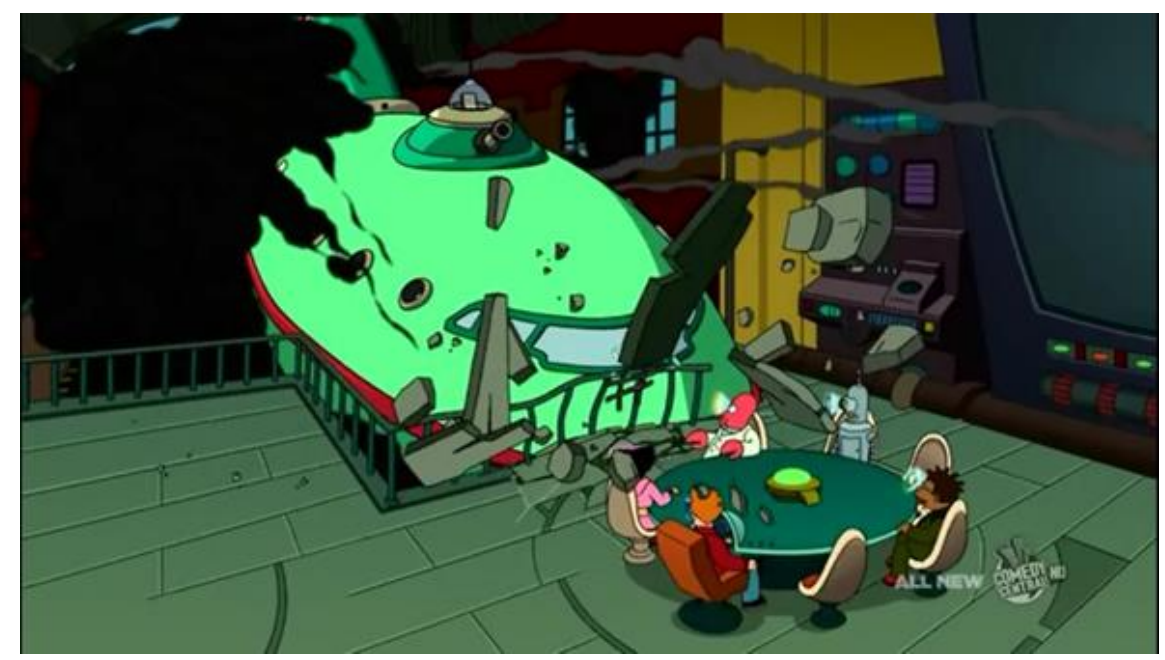

Fonte: Print screen da 6를 temporada de Futurama, Episódio 03.

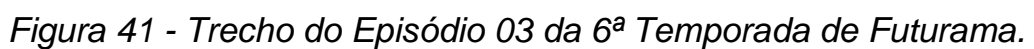

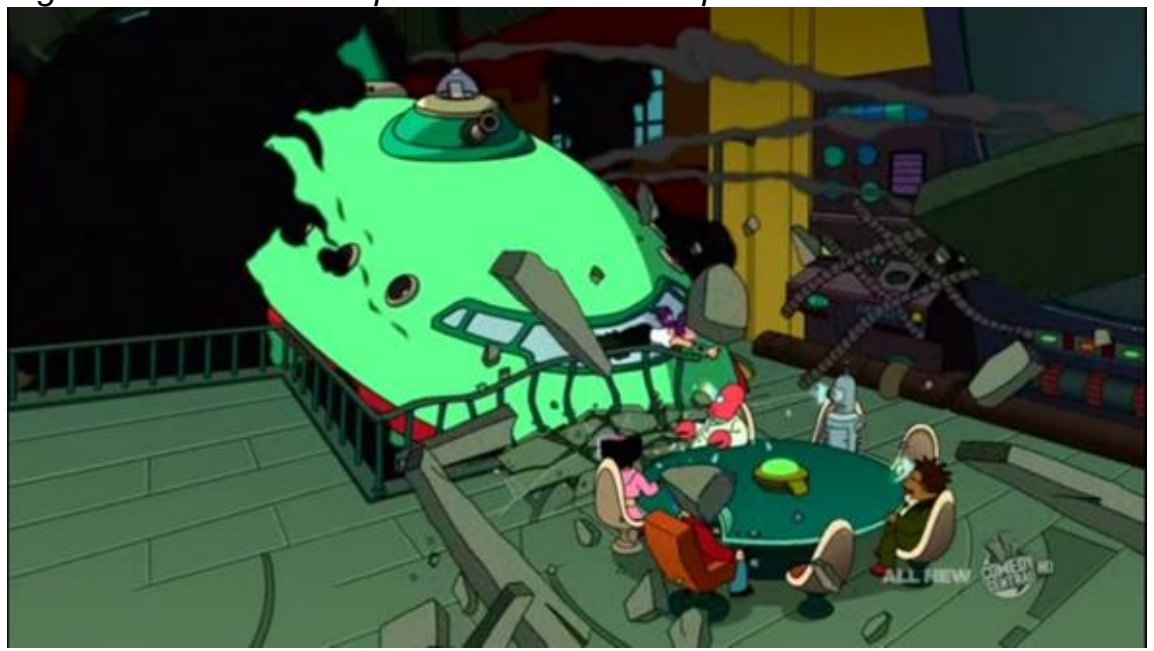

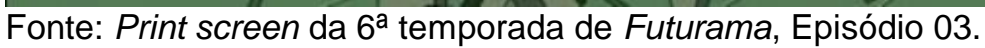

Visto de outro referencial:

Figura 42 - Trecho do Episódio 03 da 6 $6^{\underline{a}}$ Temporada de Futurama.

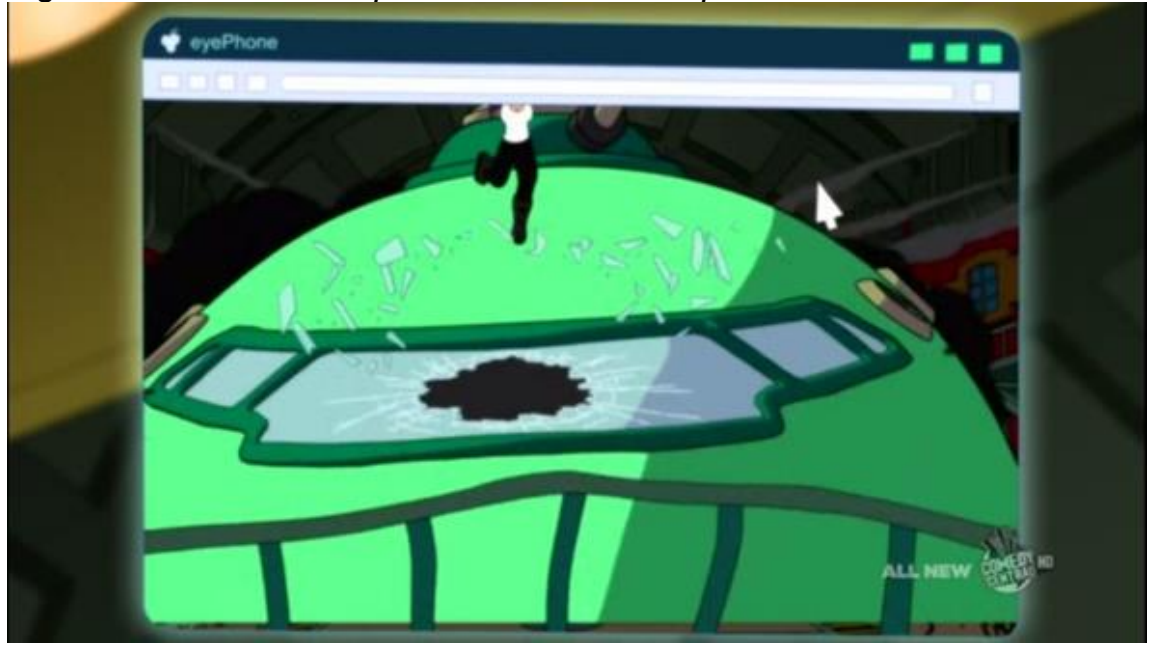


Fonte: Print screen da 6⿳亠丷厂 temporada de Futurama, Episódio 03.

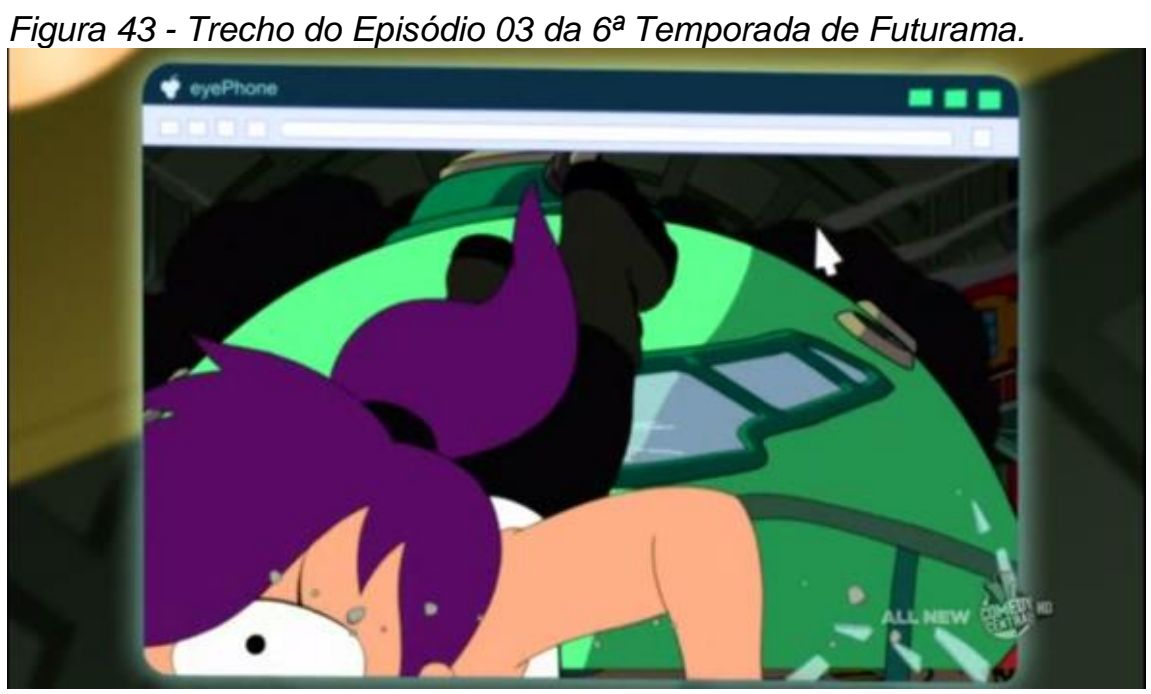

Fonte: Print screen da 6 a $^{\mathbf{a}}$ temporada de Futurama, Episódio 03.

\section{6a Temporada}

\section{Episódio 6 - Inspeção Letal}

Sinopse: Bender descobre que sua unidade de backup, a qual permite que suas memórias de um robô sejam transplantas de corpo, o que significa que ele não é imortal como pensava. Com a ajuda de Hermes, ele decide confrontar o inspetor que supervisou sua fabricação.

Intervalo de tempo utilizado: $8 \mathrm{~min} 43 \mathrm{~s}$ a $9 \mathrm{~min} 00 \mathrm{~s}$

Sinopse Física: Após Bender descobrir que não possui unidade de backup, ele procura o inspetor que o aprovou, com a ajuda de Hermes que é um burocrata. Eles então decidem ir à sede dos burocratas onde Hermes possui uma sala que se encontra em um local que possui o formato de uma variação do cubo de rubik "cubo mágico". E quando o cubo pára, uma pessoa que está na sala continua seu movimento.

Aspectos a serem explorados: Pode-se trabalhar com o conceito de inércia neste trecho, pois quando uma parte do cubo para de rodar, uma pessoa que nele estava continua seu movimento. Como nem todos percebem isso no episódio, tal pessoa em movimento foi circulada. Também se pode trabalhar com o conceito de movimento circular, pois existe rotação em torno de um eixo e pode-se comentar 
sobre a velocidade de cada um, assim como aceleração centrípeta nos quais os personagens se encontram envolvidos.

A seguir as imagens de 44 a 47 permitem a visualização de tais conceitos.

Figura 44 - Trecho do Episódio 06 da 6ª Temporada de Futurama.

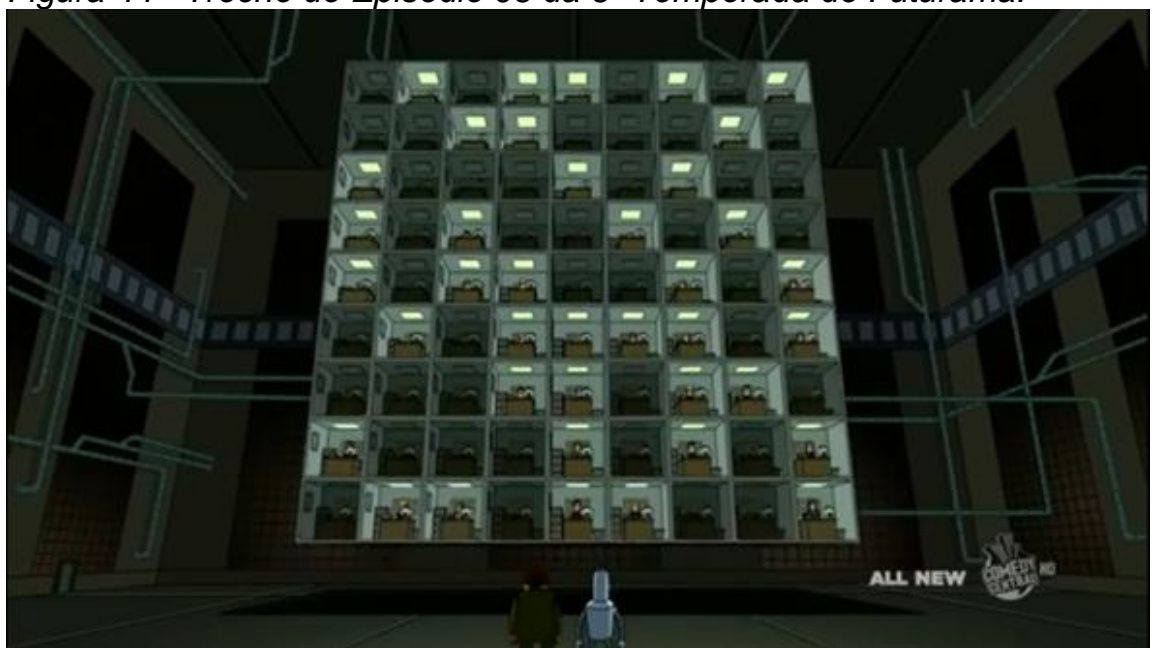

Fonte: Print screen da 6ª temporada de Futurama, Episódio 06.

Figura 45 - Trecho do Episódio 06 da 6 ${ }^{a}$ Temporada de Futurama.

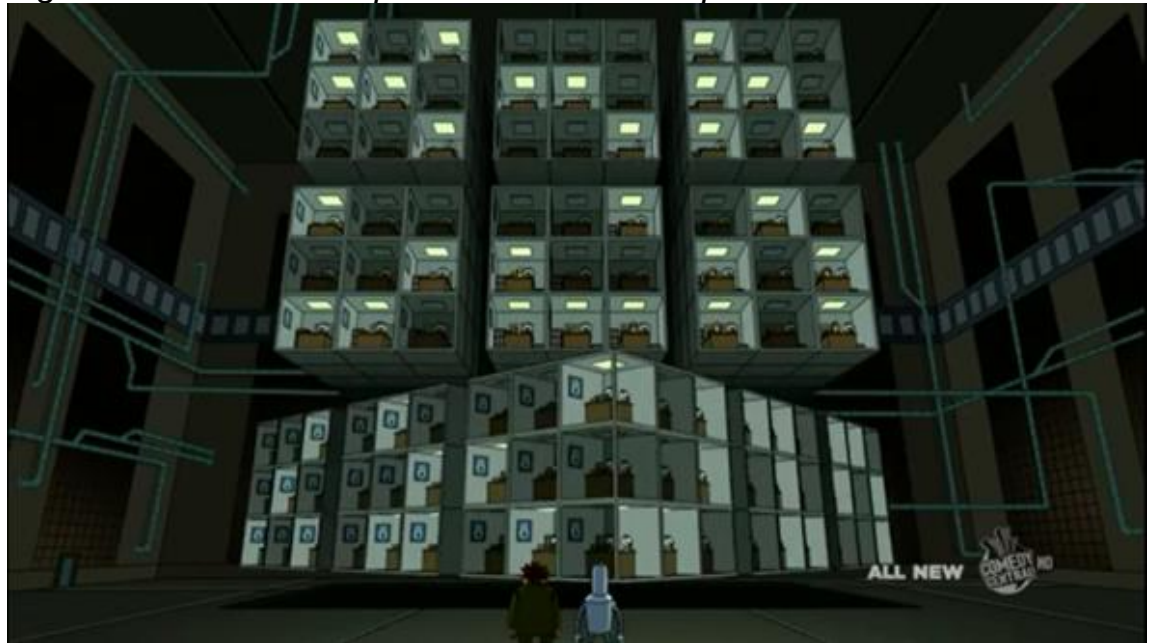


Fonte: Print screen da 6aㅗ temporada de Futurama, Episódio 06.

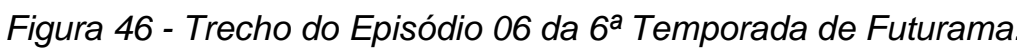

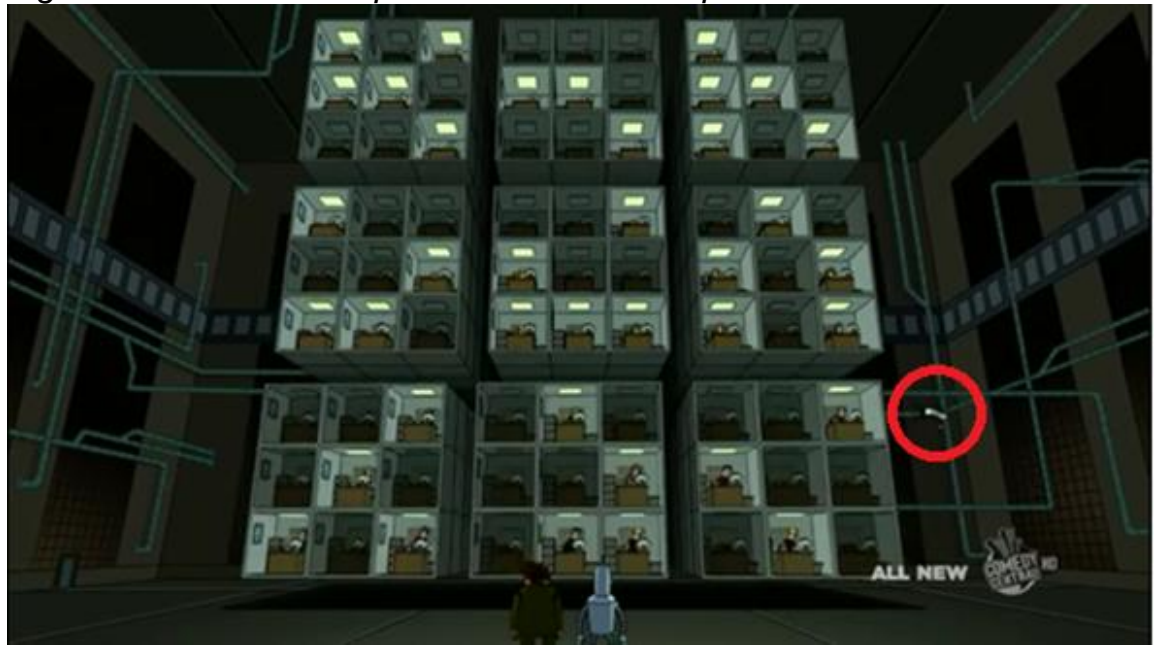

Fonte: Print screen da 6⿳亠丷厂 temporada de Futurama, Episódio 06.

Figura 47 - Trecho do Episódio 06 da 6 6⿳⺈ Temporada de Futurama.

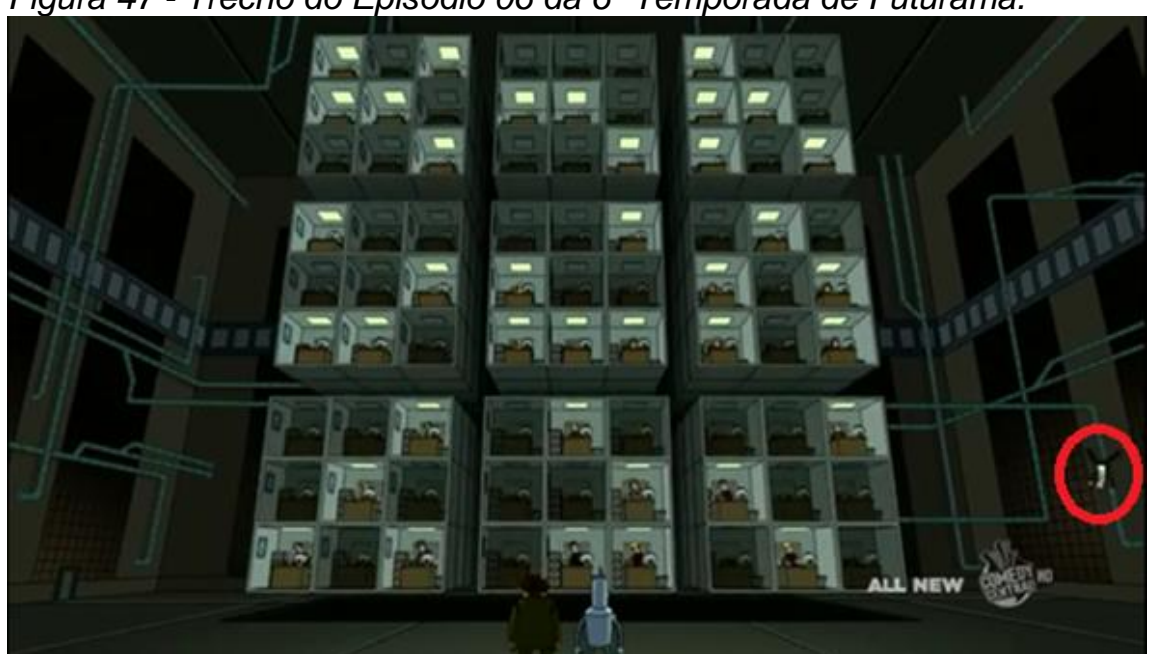

Fonte: Print screen da 6⿳亠丷厂 temporada de Futurama, Episódio 06.

6⿳⺈ Temporada

\section{Episódio 8 - Que droga, Katz!}

Sinopse: Amy desenvolve uma tese de doutorado e recebe o título de doutora ao conseguir colocar sua tese em prática.

Intervalo de tempo utilizado: $12 \mathrm{~min} 30 \mathrm{~s}$ a $21 \mathrm{~min} 00 \mathrm{~s}$

Sinopse Física: Após um experimento que faz a terra parar, vários objetos continuam em movimento. Quando a Terra volta a rodar, volta a rodar no sentido oposto, gerando uma série de problemas. 
Aspectos a serem explorados: Irradiação térmica, pois quando a Terra para de rodar, um lado fica com a temperatura muito elevada. Inércia, pois quando a Terra para de rodar bruscamente em torno do próprio eixo, vários objetos ao longo dela continuam a se mover, causando danos. Campo magnético, pois Amy utiliza um aparelho que mede o campo magnético da terra.

A seguir as imagens de 48 a 52 auxiliam na visualização do conceito de inércia. É importante que os alunos percebam tal conceito ao longo da exibição do desenho.

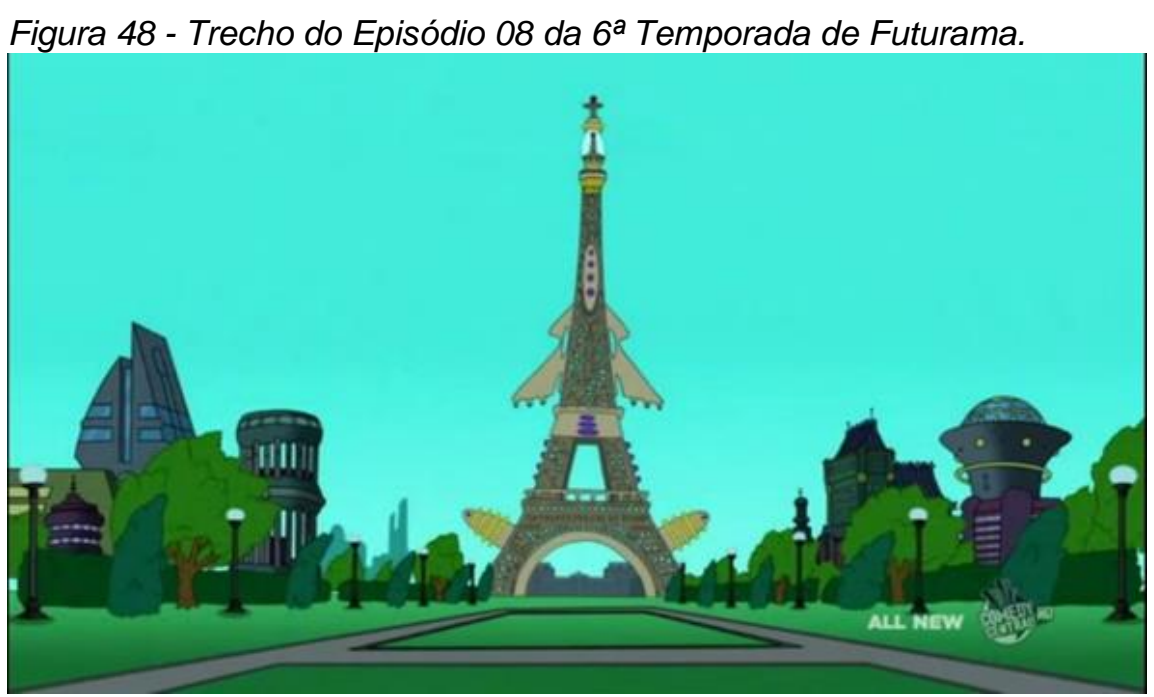

Fonte: Print screen da 6ª temporada de Futurama, Episódio 08.

Figura 49 - Trecho do Episódio 08 da 6 6ํㅡ Temporada de Futurama.

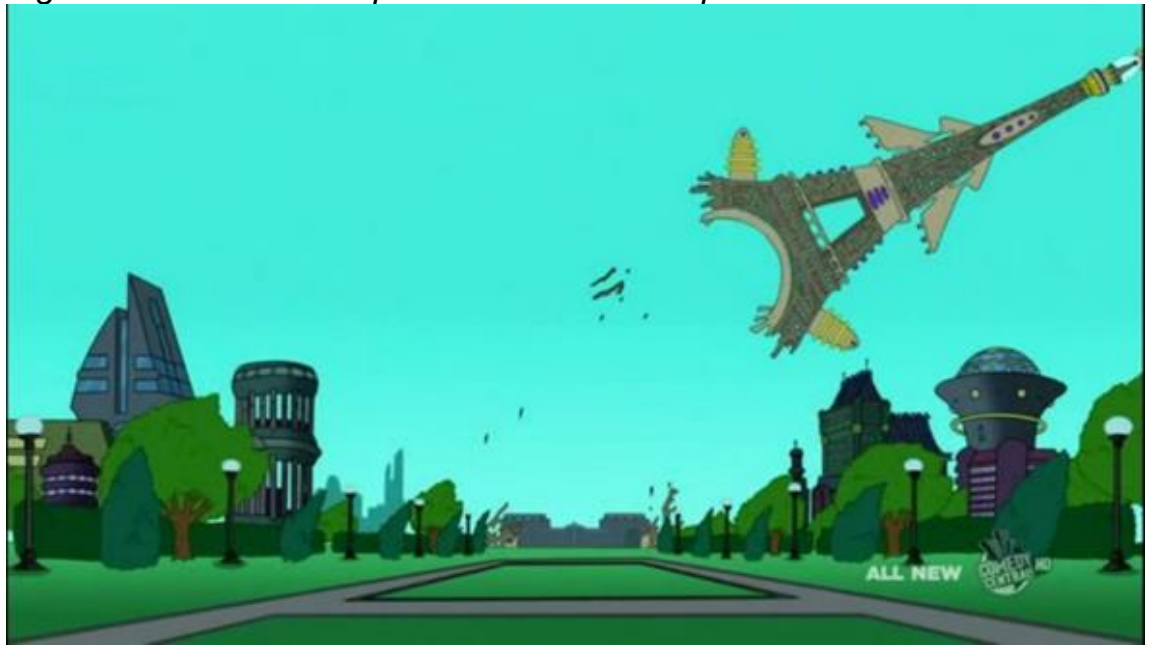

Fonte: Print screen da 6⿳亠丷厂 temporada de Futurama, Episódio 08.

Figura 50 - Trecho do Episódio 08 da 6 6 $^{\underline{a}}$ Temporada de Futurama. 


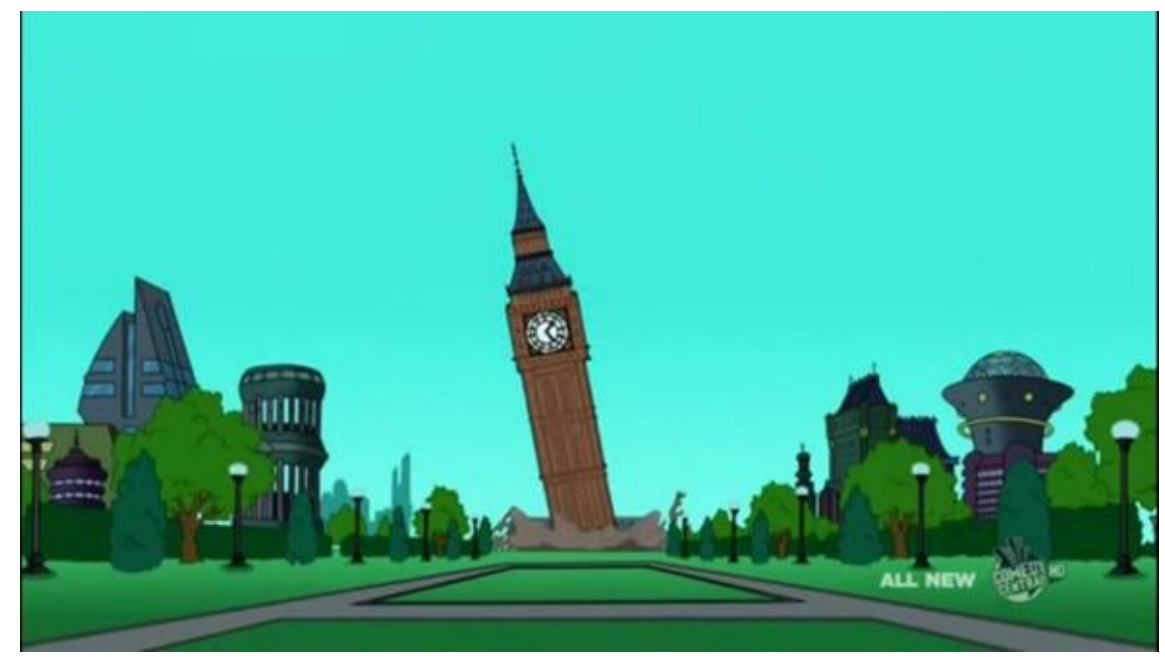

Fonte: Print screen da 6⿳⺈ temporada de Futurama, Episódio 08.

Figura 51 - Trecho do Episódio 08 da 6 6 Temporada de Futurama.

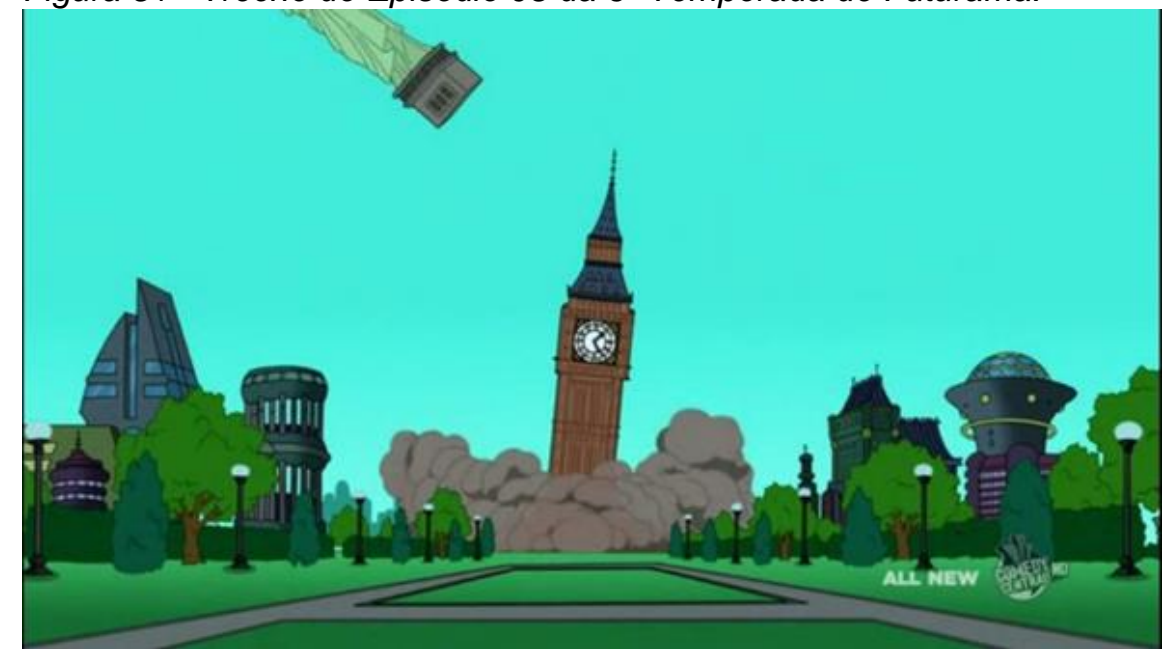

Fonte: Print screen da 6aㅗ temporada de Futurama, Episódio 08.

Figura 52 - Trecho do Episódio 08 da $6^{\underline{a}}$ Temporada de Futurama.

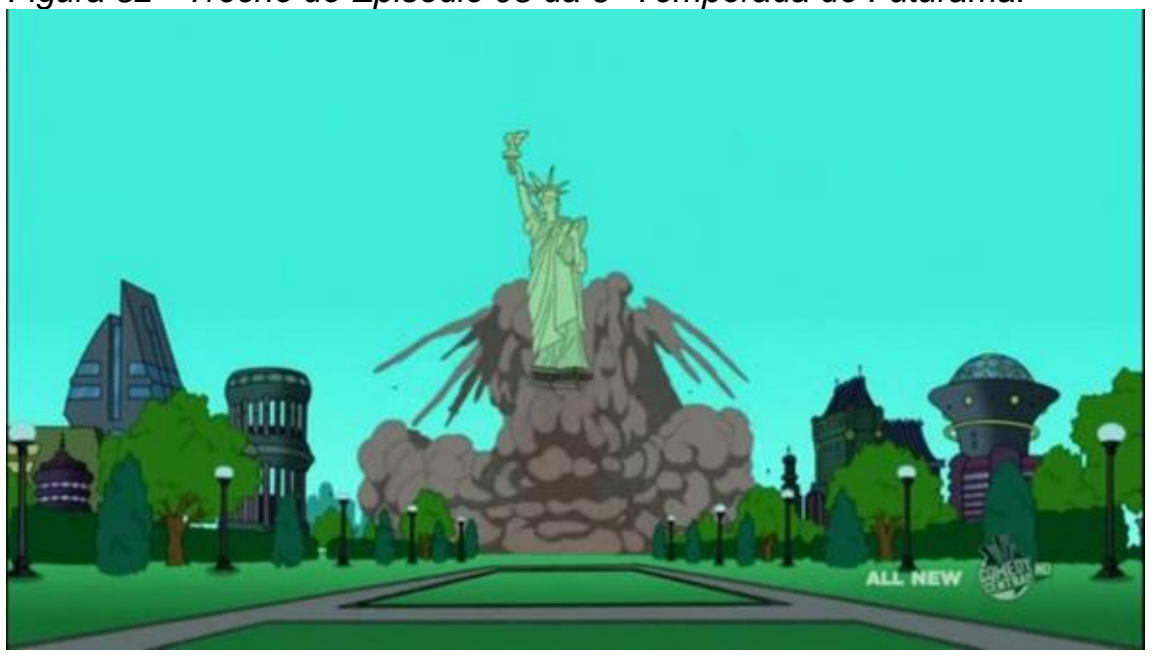

Fonte: Print screen da 6⿳亠丷厂 temporada de Futurama, Episódio 08. 


\subsection{METODOLOGIA DA PESQUISA (PRODUTO: ANTES, DURANTE E}

DEPOIS)

Ao definir Futurama como meio de ensino de conceitos introdutórios de física, em especial o conceito de inércia, foi iniciada uma pesquisa com o objetivo de traduzir em números as opiniões e o aprendizado dos alunos com o uso deste desenho animado em sala de aula.

A pesquisa também busca estabelecer dados qualitativos, pois procura criar um vínculo entre o uso do desenho animado para o ensino e o grau de motivação demonstrado pelos alunos com relação à disciplina física.

A pesquisa foi iniciada com a aplicação de um questionário que aborda a visão que os alunos possuem da disciplina física e como eles a percebem em seu cotidiano. O questionário foi aplicado durante uma aula regular de física com duração de 50 minutos e os dados de tal questionário são analisados em maiores detalhes no capítulo 7 , que trata da apresentação e da discussão dos dados coletados.

Após a aplicação do questionário, uma segunda aula foi selecionada para a exibição dos episódios do desenho animado Futurama. Posteriormente, uma terceira aula foi selecionada para explicar de forma expositiva o conceito de inércia, assim como ensinar de forma mais teórica a primeira Lei de Newton. Durante esta aula, o conceito de inércia foi apresentado aos alunos da seguinte forma: "Lei da Inércia: Todo corpo continua em seu estado de repouso, ou movimento uniforme em linha reta, a menos que ele seja compelido a mudar este estado em razão de uma força impressa sobre ele". (POLITO, 2015).

Em seguida, uma quarta aula foi selecionada para ensinar de modo mais prático e lúdico o conceito de inércia. Durante esta aula, foram feitos dois experimentos que demonstram a primeira Lei de Newton de modo visível para os alunos. O primeiro experimento envolve o uso de um aparelho de limpeza que consiste em um esfregão e um balde com um cesto giratório. Para secar o esfregão, o usuário do aparelho deve colocá-lo no cesto giratório, onde a rotação o seca, demonstrando assim o conceito de inércia. $O$ segundo experimento consiste em 
colocar uma moeda em cima de um papel cartão, que, por sua vez, encontra-se sobre um copo. Ao bater rápido no papel cartão, a moeda cai dentro do copo, o que exemplifica o conceito de inércia.

Após a apresentação dos dois experimentos, um novo questionário foi aplicado. Apenas 51 alunos responderam, pois dois alunos faltaram a esta aula.

Os dados coletados neste segundo questionário foram compilados e são analisados em detalhes no capítulo 7, que trata da apresentação e da discussão dos dados coletados.

Tais dados deram origem ao produto educacional "O Ensino de Inércia com Desenhos Animados, com a utilização de Futurama como ferramenta lúdica", uma cartilha destinada a professores de física que desejem utilizar desenhos animados, no caso Futurama, como uma alternativa com abordagem lúdica para o ensino do conceito de inércia.

\subsection{AVALIAÇÃO DA PROPOSTA}

Após a aplicação do produto, um questionário foi respondido pelos alunos, no qual contavam uma avaliação da aprendizagem formada por quatro questões.

O objetivo do questionário era verificar se houve aprendizagem do conceito inércia pelos alunos que participaram da pesquisa por meio do uso do produto educacional.

Com o intuito de analisar se a proposta da pesquisa foi cumprida, do ponto de vista dos sujeitos desse trabalho, foi aplicado um outro questionário intitulado Questionário Pós -Teste, que se encontra como apêndice D. Ele consiste de uma análise qualitativa do trabalho feita pelos estudantes a qual consiste em quatro perguntas discursivas.

Os resultados da aplicação da avaliação da aprendizagem e do questionário pós-teste são discutidos no capítulo 7. 


\section{ANÁLISE E DISCUSSÃO DOS DADOS}

Neste capítulo se descreve os dados obtidos durante a pesquisa através de dois questionários, assim como discutir os resultados coletados a partir da pesquisa do ensino de física com o uso do desenho animado Futurama.

O capítulo está dividido em três partes - a primeira referente aos dados coletados em um questionário aplicado antes da exibição dos trechos de Futurama, doravante chamada de pré-questionário, a segunda referente aos dados coletados em um questionário aplicado após a exibição dos trechos, doravante chamado de pós-questionário, a terceira consiste em uma análise qualitativa feita pelos estudantes, que possui quatro perguntas discursivas.

\subsection{ANÁLISE E DISCUSSÃO DO PRÉ-QUESTIONÁRIO}

O pré-questionário foi aplicado a 53 alunos do $9^{\circ}$ Ano do ensino fundamental com o intuito de coletar dados sobre o perfil do respondente, no qual são solicitadas informações sobre faixa etária, nível educacional, contexto socioeconômico e cultural. Além do perfil, o questionário também inclui perguntas sobre a experiência particular dos alunos com relação aos seus estudos em Física.

Tal questionário foi elaborado com o auxílio da professora orientadora, Adriana Pereira Ibaldo, sendo suas perguntas parcialmente baseadas em sua pesquisa "Atracting girls and Young women from Distrito Federal (DF, Brazil) to pursue a carreer in Physics: first studies" (IBALDO, 2015). As perguntas 11, 14, 15, $16,18,20,21,27,28,29$ e 30 foram retiradas deste trabalho, pois se aplicavam ao contexto do presente trabalho.

Os primeiros dados coletados foram em relação à situação socioeconômica dos alunos, sendo que as duas primeiras questões estão relacionadas à gênero e idade dos alunos. Desta forma, e possível determinar que o estudo foi feito com alunos com a faixa etária de 13 a 15 anos e que dos 53 alunos participantes, 28 eram do sexo masculino e 25 do sexo feminino.

A terceira questão está relacionada ao número de alunos que possuem televisão a cabo em seu domicílio. Entre os sujeitos pesquisados, 43 alunos 
declararam possuir TV a cabo em seu domicílio, o que pode ser visualizado no gráfico 1 disposto a seguir.

GRÁFICO 01 - Você possui TV a cabo em casa?

\section{Estudantes que têm Tv a cabo em casa?}

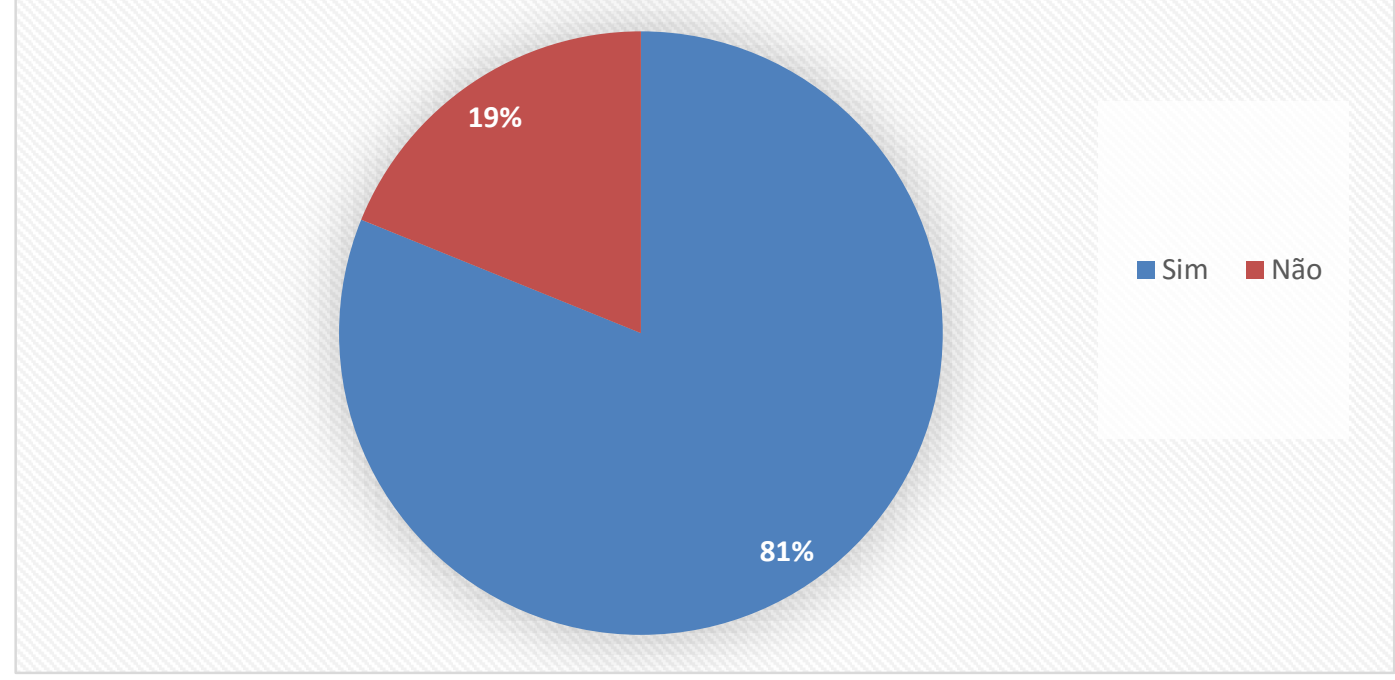

Fonte: Elaboração própria.

Segundo dados fornecidos pela ANATEL $^{8}$ em fevereiro de 2015, a cada 100 domicílios, existem em média 56 assinaturas de TV a Cabo no DF. O grupo pesquisado difere desta média, pois $81,1 \%$ dos alunos declararam ter TV a Cabo. Este fato influencia a pesquisa, pois a probabilidade dos alunos terem acesso ao desenho Futurama, que é exibido unicamente na TV a Cabo, é maior.

A próxima questão listada na pesquisa diz respeito ao número de horas que cada estudante gasta assistindo à TV a cabo. A maioria dos alunos (36\%) declarou gastar de 2 a 3 horas diárias em frente ao aparelho conforme o gráfico 02.

\footnotetext{
8 Disponível em http://www.anatel.gov.br/Portal/exibirPortalNoticias.do?acao=carregaNoticia\&codigo=36830 acesso em 19 de abril de 2015
} 
GRÁFICO 02 - Horas diárias assistindo TV.

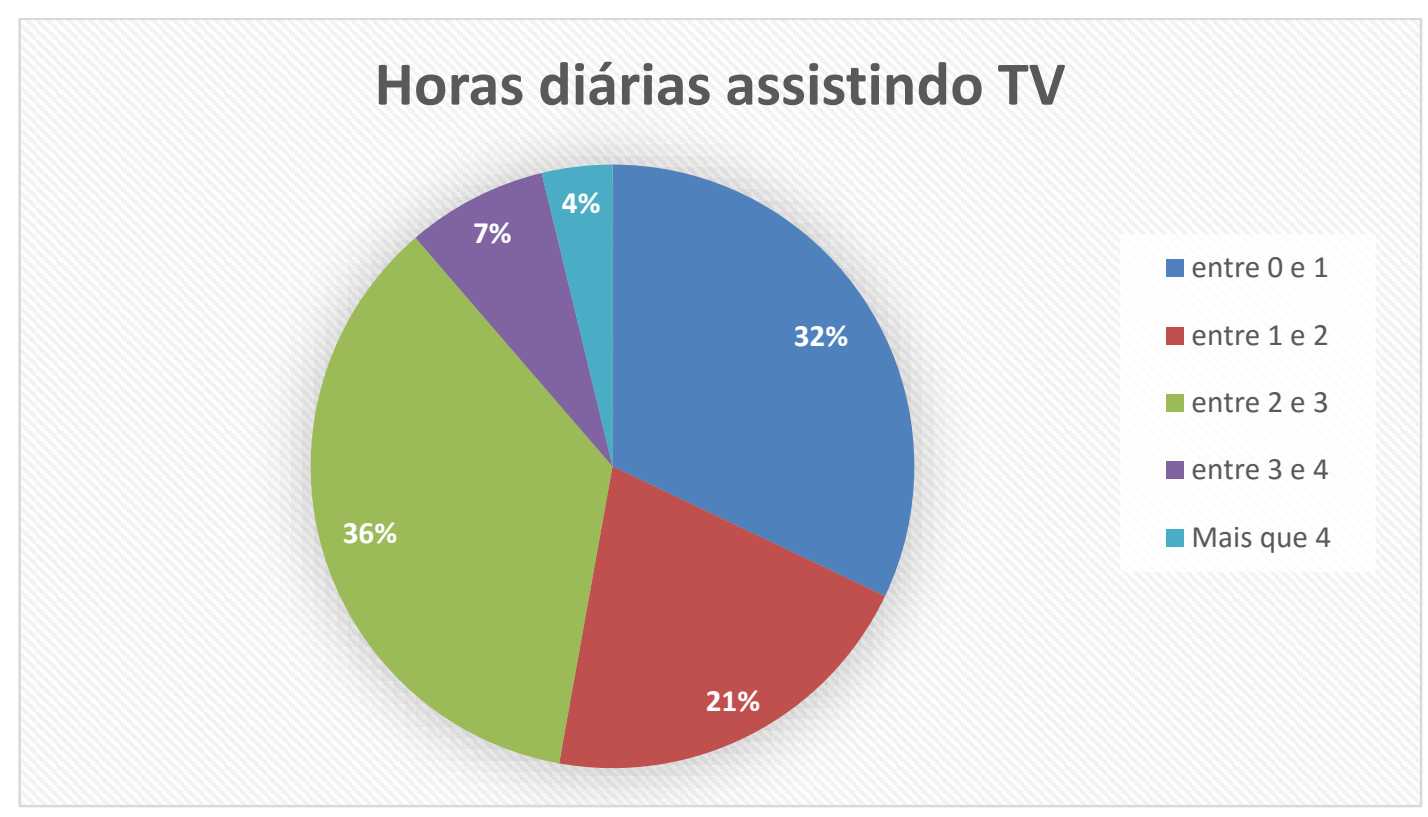

Fonte: Elaboração própria.

Ao empregar-se a média aritmética simples aos dados fornecidos pelos alunos, apresenta-se um valor de 1,8 horas assistindo TV por dia, durante as quais os alunos são expostos a diversos programas de televisão, como séries, desenhos, noticiários e esportes. O questionário solicita aos alunos que explicitem se gostam de desenhos animados. Entre os estudantes pesquisados, o percentual total de alunos que gostam de desenhos animados é igual a $61 \%$, fato ilustrado pelo gráfico 03. 
GRÁFICO 03 - Estudantes que gostam de desenhos animados.

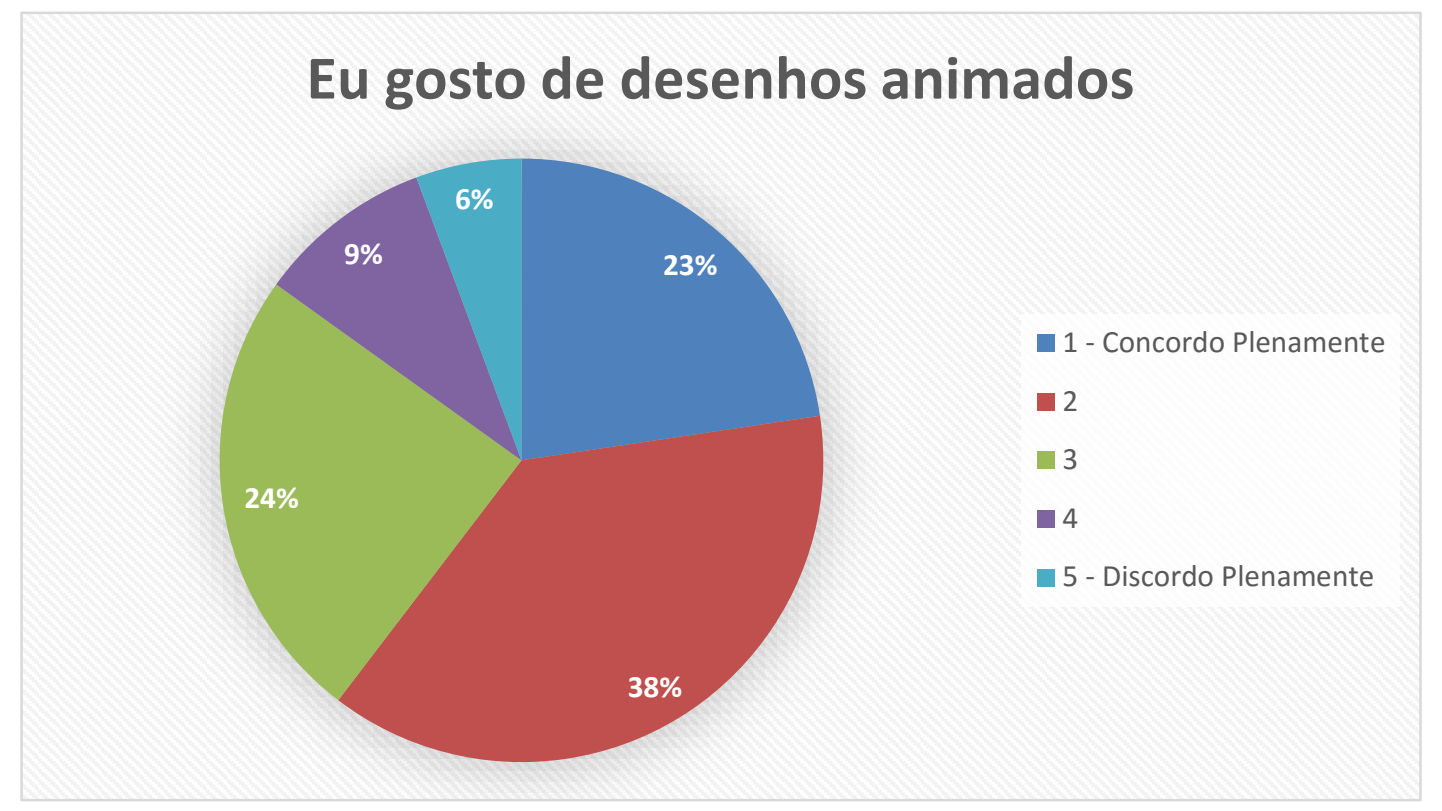

Fonte: Elaboração própria.

Se o número de alunos indiferentes for acrescido aos $61 \%$ dos sujeitos que gostam de desenhos animados, chega-se ao percentual total de $85 \%$ dos alunos um número significativo de sujeitos que estão sensíveis ao uso de desenhos animados como ferramenta de ensino. Desta maneira, ao relacionar o ensino com algo que os alunos já estão familiarizados e que já declararam gostar, o professor estimula e motiva seus alunos a estudar, tornando a aprendizagem significativa, fato corroborado pela teoria de Ausubel. Além disso, mais do que apenas indicar dados, os números apontam para a aceitação de um produto que relacione o desenho com o ensino de conceitos introdutórios de física, algo proposto pelo autor da pesquisa.

$O$ questionário segue com perguntas referentes à visão dos alunos com relação à disciplina física. A primeira pergunta deste cunho foi "A Física consiste apenas em aplicar fórmulas matemáticas". Em tal questão, $52,8 \%$ dos estudantes discordaram totalmente. Outro questionamento feito aos alunos foi a respeito de acharem a física inútil em seu cotidiano. Neste caso, $41 \%$ dos alunos discordaram totalmente, fato ilustrado pelo gráfico 04 . 
GRÁFICO 04 - Eu acho que os conceitos de física são inúteis na minha vida.

\section{Eu acho que os conceitos de física são inúteis para a minha vida}

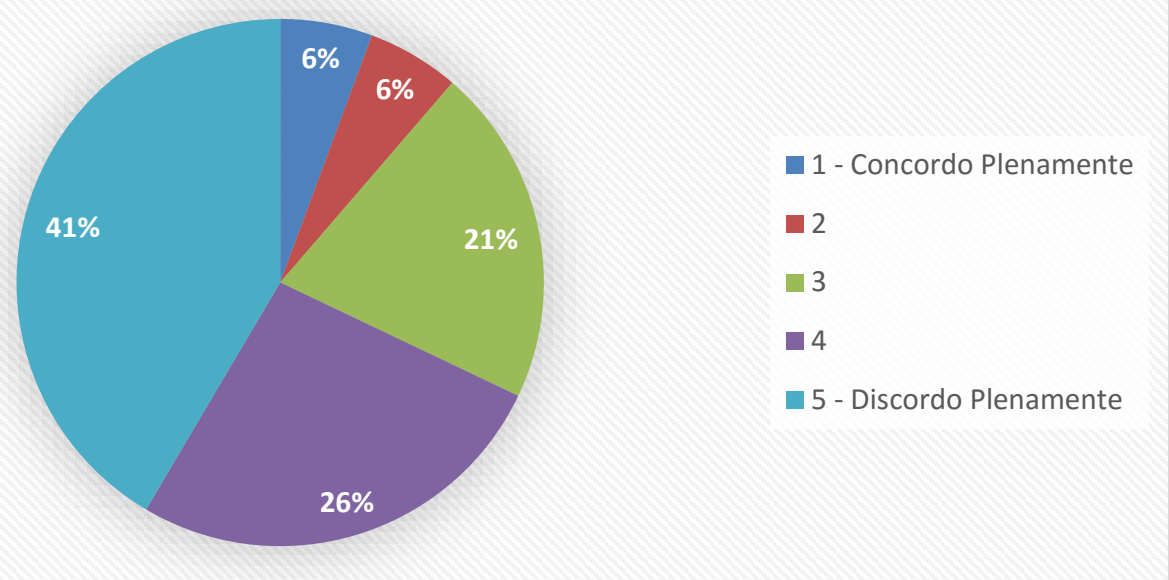

Fonte: Elaboração própria.

Outro questionamento feito aos alunos foi sobre o fato de a física não explicar o ambiente ao redor deles. Para esta questão, $58 \%$ dos alunos discordaram, fato expresso pelo gráfico 05 .

GRÁFICO 05 - A física não explica o ambiente ao meu redor.

A física não explica o ambiente ao meu redor

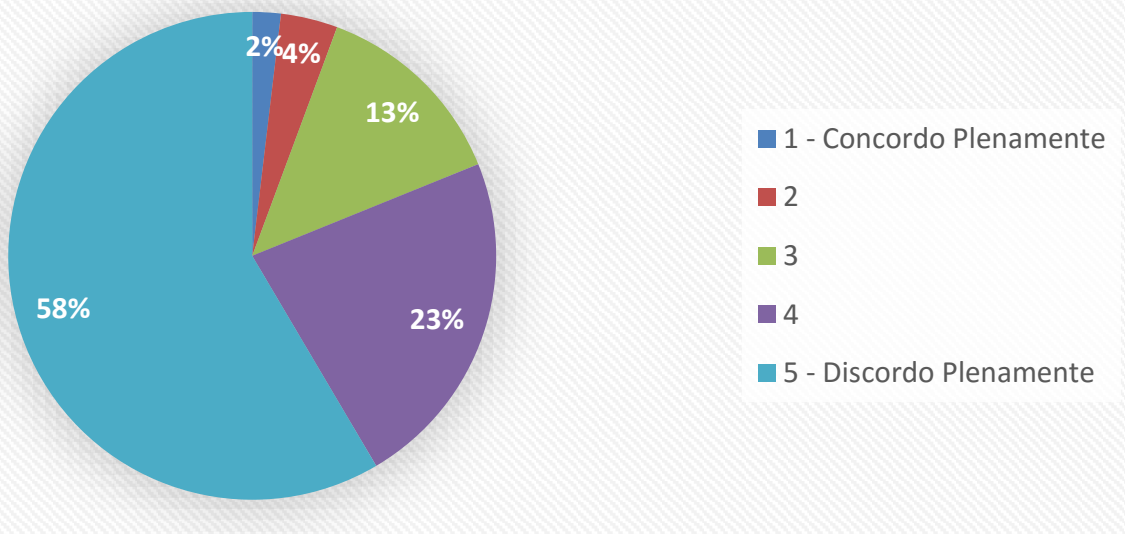

Fonte: Elaboração própria. 
Os dados expressos nos gráficos 04 e 05 permitem concluir que os alunos possuem uma visão favorável de física, pois apenas $6 \%$ dos alunos concordam que a física não explica o ambiente ao redor e apenas $12 \%$ dos estudantes concordam que os conceitos de física são inúteis para a própria vida.

Em seguida, é perguntado aos alunos acerca da relação entre os conceitos de física e o desenvolvimento tecnológico. Para esta questão, $56 \%$ dos alunos concordaram plenamente e nenhum dos alunos discordam plenamente, como pode ser visualizado no gráfico 06 .

GRÁFICO 06 - Os conceitos de física são muito importantes para o desenvolvimento tecnológico.

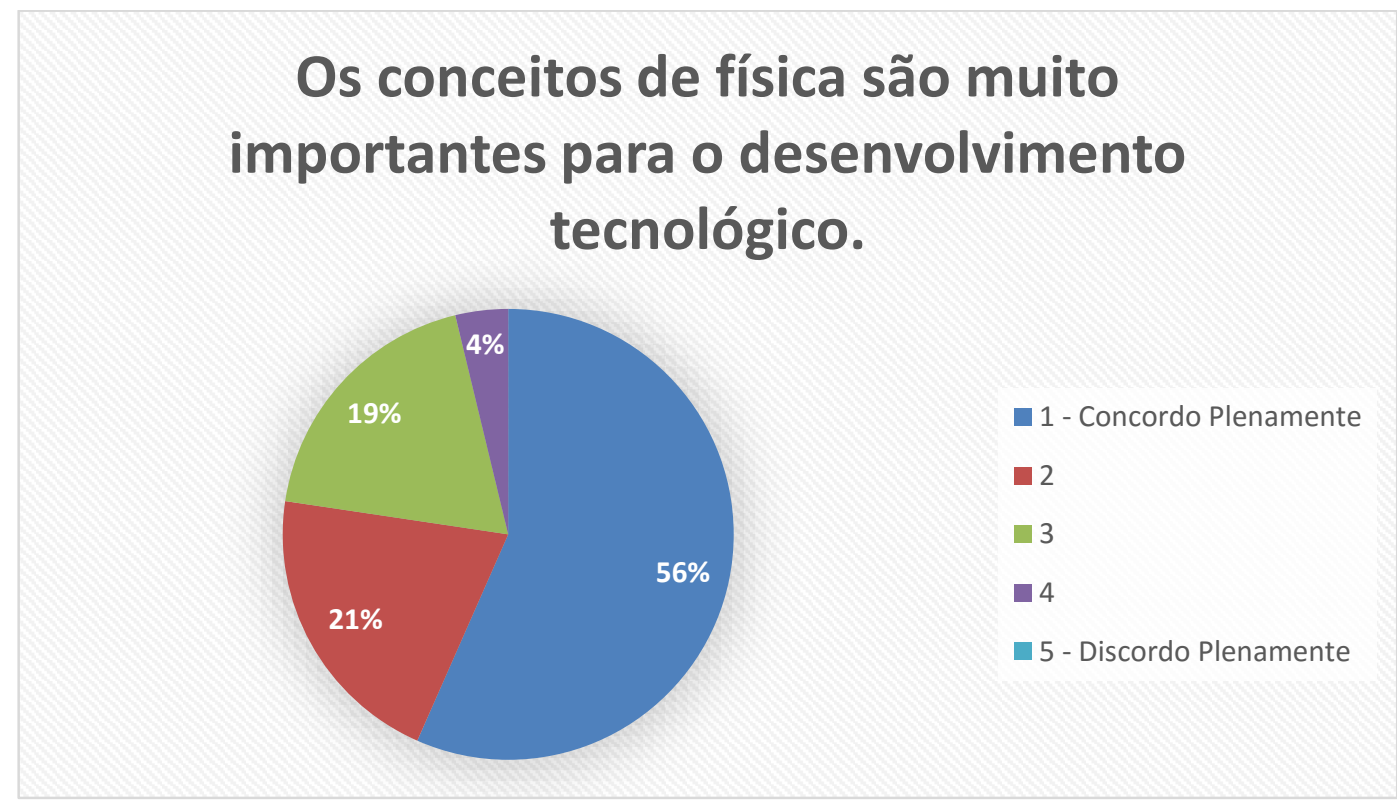

Fonte: Elaboração própria.

O sexto gráfico confirma a visão dos estudantes a respeito da importância da física para o desenvolvimento tecnológico, o que demonstra que, para os alunos, a física é uma disciplina importante para a vida das pessoas. Conclui-se isso devido ao fato de os estudantes confirmarem que a física não é inútil para a vida deles e que ela pode explicar alguns fenômenos. Além disso, eles reconhecem a importância da disciplina para o desenvolvimento tecnológico. Dentro desta perspectiva, infere-se que os alunos têm interesse na disciplina e precisam apenas ser mais estimulados a pensar em ciência. E é dentro desta perspectiva que foi 
criado o produto educacional "O Ensino de Inércia com Desenhos Animados, com a utilização de Futurama como ferramenta lúdica", como forma de estímulo ao estudo da física.

A próxima questão no formulário aborda a relação entre o conteúdo ministrado e aos exercícios referentes a ele. Neste caso, $59 \%$ dos alunos veem uma relação entre o que é colocado no livro-texto e os problemas de física que são resolvidos em sala, como demonstrado no gráfico 7 .

GRÁFICO 07 - Quando estou resolvendo problemas de física não vejo relação com o que foi visto na aula e/ou livro-texto.

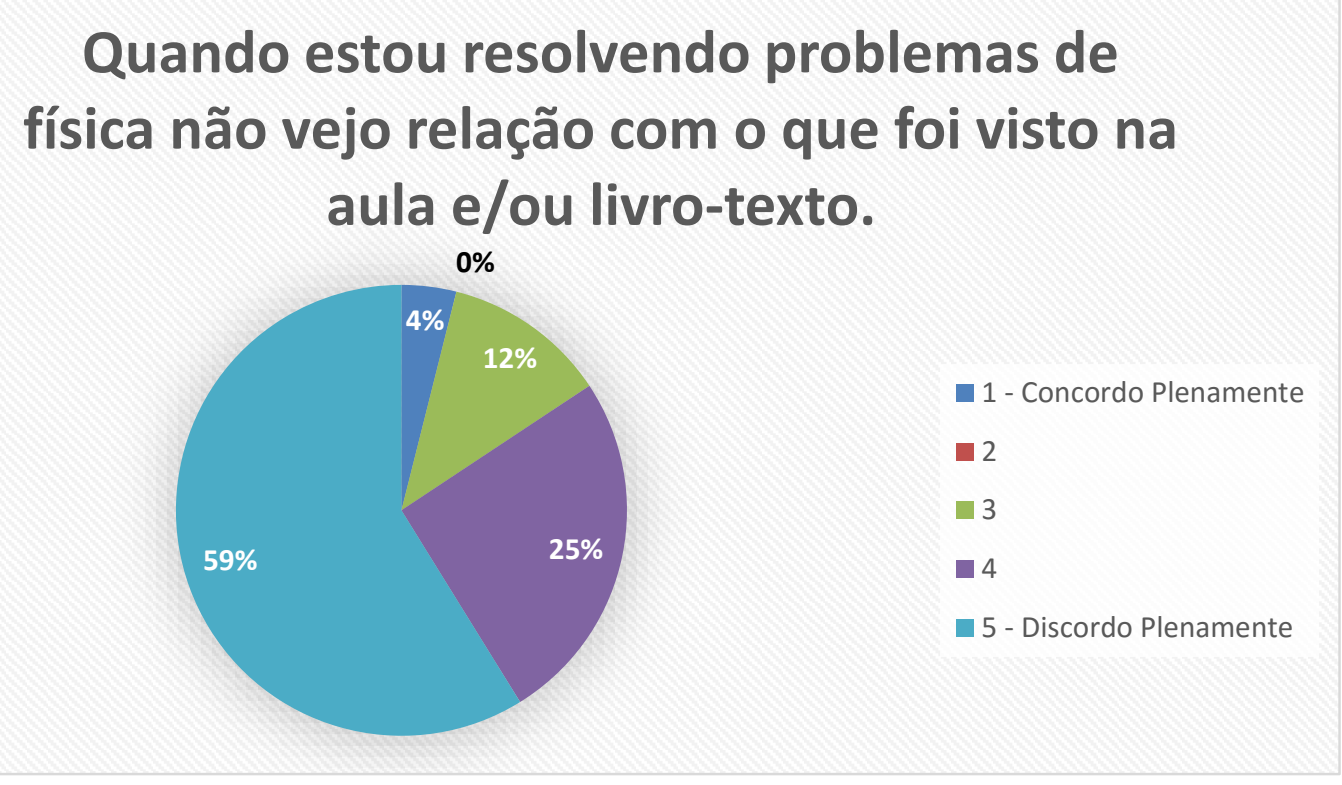

Fonte: Elaboração própria.

Em seguida, é questionado aos alunos a facilidade que eles possuem em aprender Física e Matemática, uma vez que no senso comum os estudantes costumam relacionar física e matemática. Nesta questão, $26 \%$ dos alunos discordaram plenamente e $23 \%$ discordaram, segundo o gráfico 08 abaixo. 
GRÁFICO 08 - Tenho facilidade para aprender Física e Matemática.

\section{Tenho facilidade para aprender Física e Matemática}

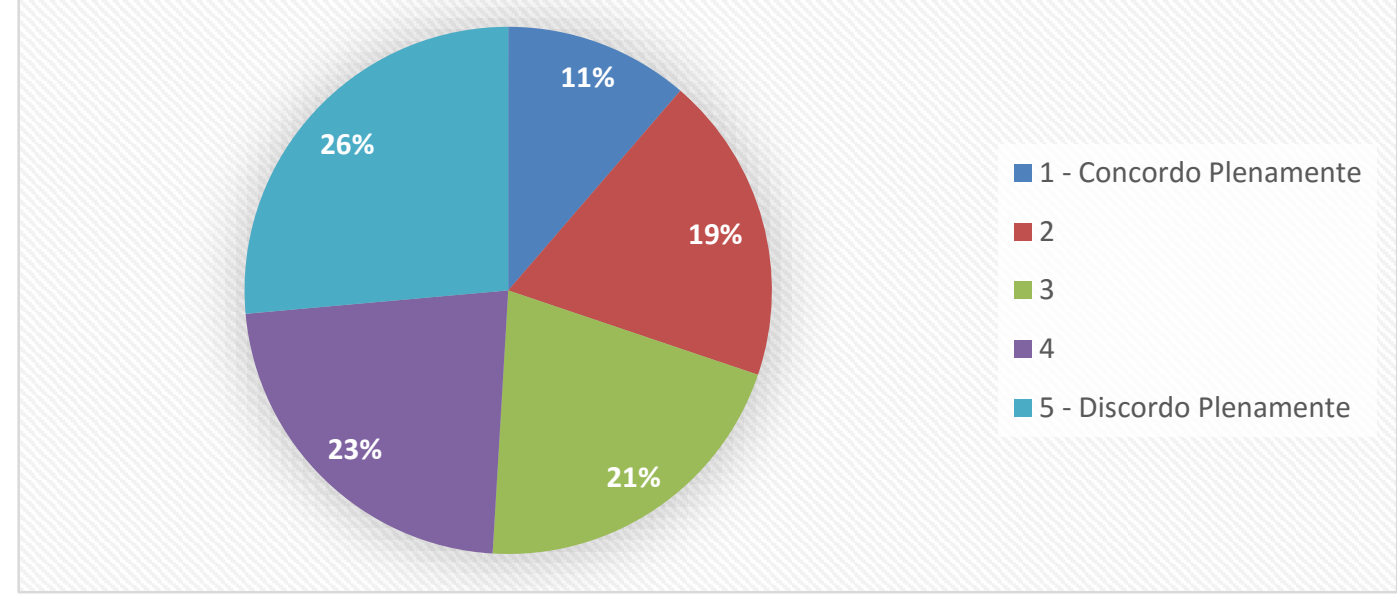

Fonte: Elaboração própria.

Assim, baseado nos gráficos 07 e 08, conclui-se que os estudantes percebem que o conteúdo abordado em sala é cobrado em exercícios, mas nem sempre conseguem assimilá-lo com facilidade.

Isso pode indicar que os exercícios a serem cobrados precisam ser mais parecidos com aqueles que são trabalhados em sala. Ou seja, é necessário que os conteúdos sejam trabalhados dentro da zona de desenvolvimento proximal dos alunos, como sugere Vygotsky, de modo a facilitar o entendimento e evitar a rejeição pela disciplina.

Outra questão abordada no pré-questionário foi o gosto dos alunos pela física. Nesta questão, 09 alunos entre os 53 pesquisados declararam não gostar da disciplina, enquanto 15 declararam gostar. $O$ registro dos dados da pergunta encontra-se no gráfico 09 a seguir. 
GRÁFICO 09 - Gosto dos estudantes por física.

\section{Eu não gosto de Física}

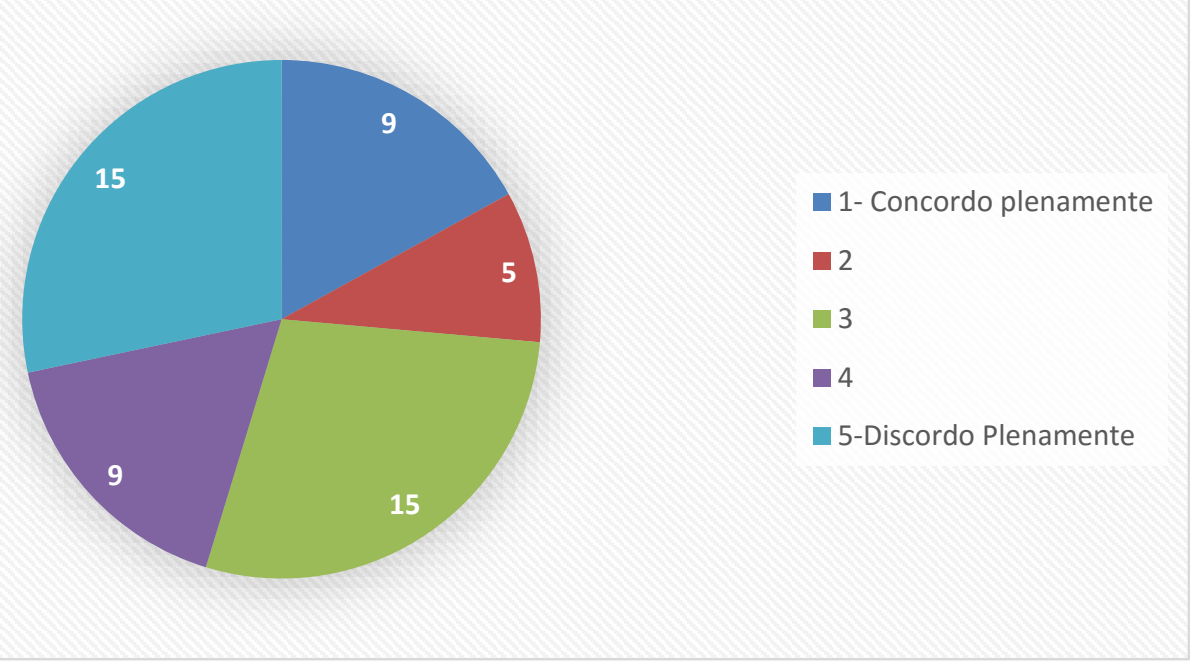

Fonte: Elaboração própria.

Também foi pesquisado junto aos alunos se eles eram capazes de entender e diferenciar a física da matemática. Tal questionamento foi feito através da pergunta "A física consiste apenas em aplicar fórmulas matemáticas". Para esta pergunta, $52 \%$ dos alunos discordaram (26 totalmente e 26 parcialmente) como ilustrado no gráfico 10.

GRÁFICO 10 - A física consiste apenas em aplicar fórmulas matemáticas. 


\section{A Física consiste apenas em aplicar fórmulas matemáticas}

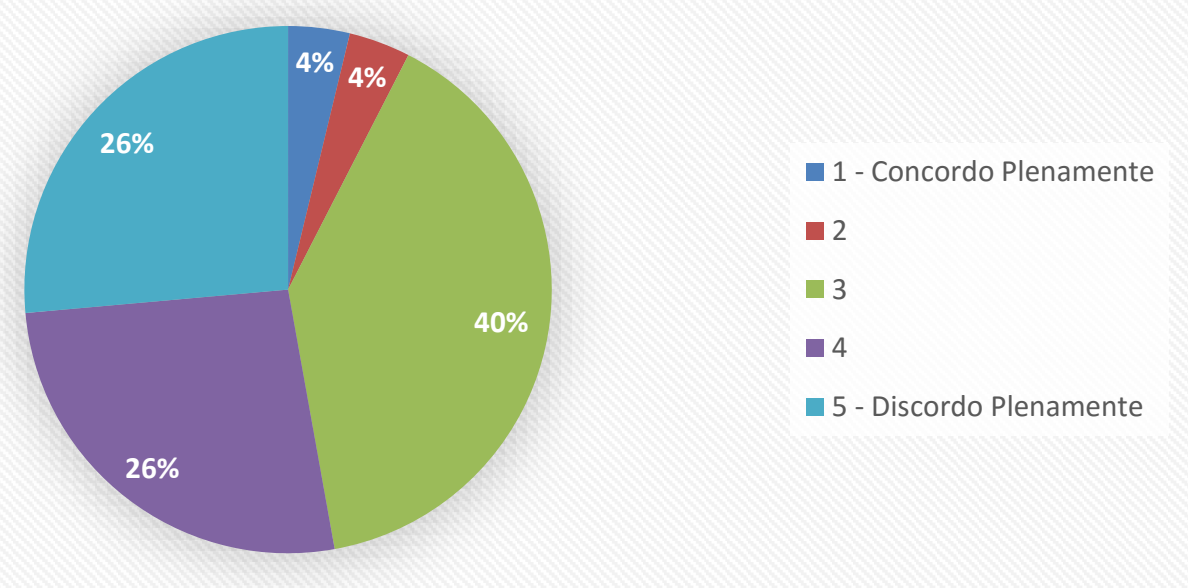

Fonte: Elaboração própria.

Tanto o gráfico 09 quanto o 10 são de extrema importância para a pesquisa, pois após a exibição dos trechos de Futurama e a aplicação do produto educacional, foi feita uma análise qualitativa com relação à aceitação da disciplina, assim como o aumento da aprendizagem de conceitos físicos.

Também foi de extrema importância verificar se os alunos já tiveram contato com o desenho animado Futurama. Assim, no questionário foi averiguado o quantitativo de alunos que já conheciam o desenho. Entre os sujeitos pesquisados, $74 \%$ declararam ter visto o desenho, enquanto apenas $26 \%$ declararam não ter visto. Tais dados podem ser verificados no gráfico 11 explicitado abaixo:

GRÁFICO 11 - Você conhece o desenho Futurama? 


\section{Você conhece o desenho Futurama?}

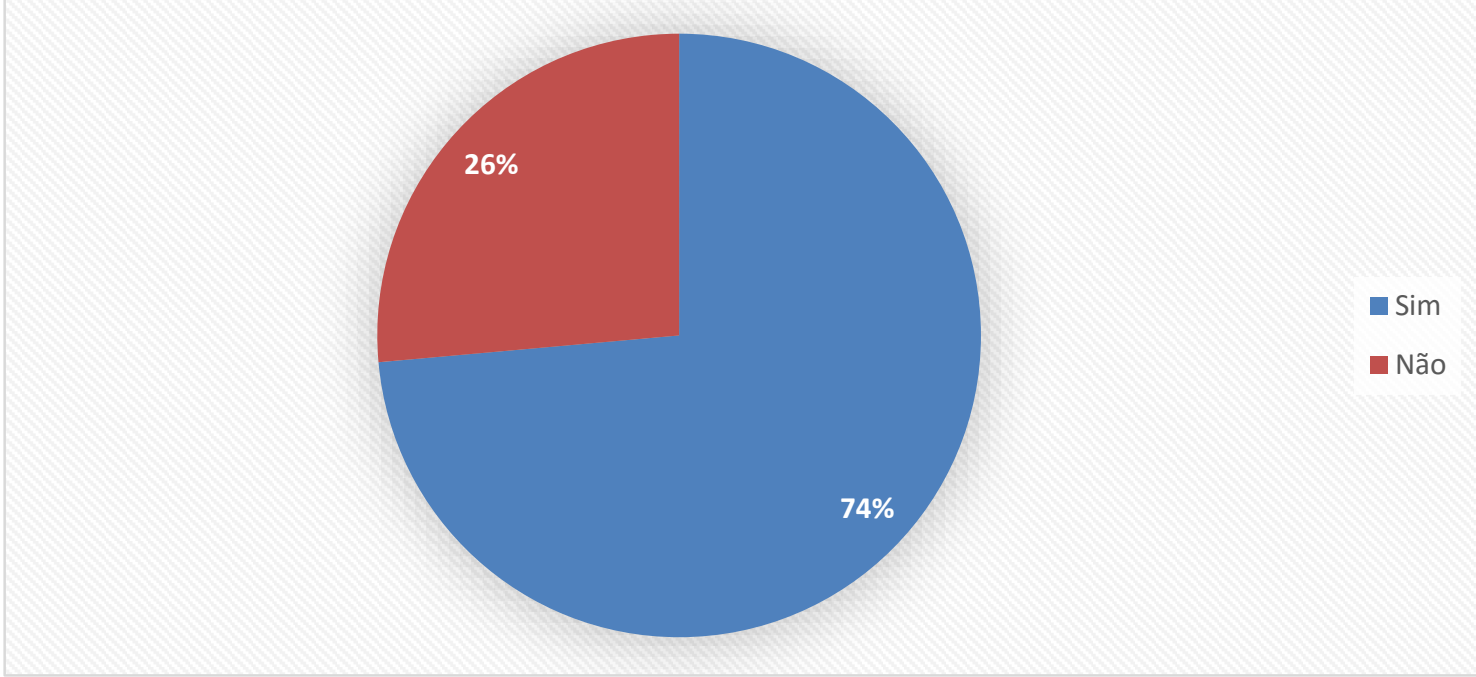

Fonte: Elaboração própria.

O fato da maioria dos alunos conhecer o desenho, que possui uma linguagem informal, próxima à linguagem empregada pelos alunos, pode ser considerado uma vantagem do ponto de vista educacional. Isto ocorre porque, segundo Vygotsky, a linguagem é o principal signo, pois é por meio dela que ocorrem as interações sociais que propiciam a aprendizagem. Além disso, outra vantagem percebida pela pesquisa é o fato de $64,2 \%$ alunos terem respondido negativamente à pergunta do questionário "Em algum desenho animado você já percebeu os conceitos de física?". Os demais alunos que responderam positivamente à pergunta disseram ter percebido apenas o conceito de velocidade em desenhos. Tais dados constituem uma vantagem, pois indicam que o produto educacional resultante da pesquisa seria de fato um novo meio de ensinar conceitos físicos para os alunos.

Outro questionamento feito aos alunos diz respeito à aceitação do desenho Futurama. A questão "Eu não gosto do programa Futurama" é um indicativo do interesse dos estudantes pelo desenho, no qual alunos neutros e que gostam do desenho somam o total de $85 \%$, como demonstrado gráfico 12 abaixo.

GRÁFICO 12 - Eu não gosto do programa Futurama. 


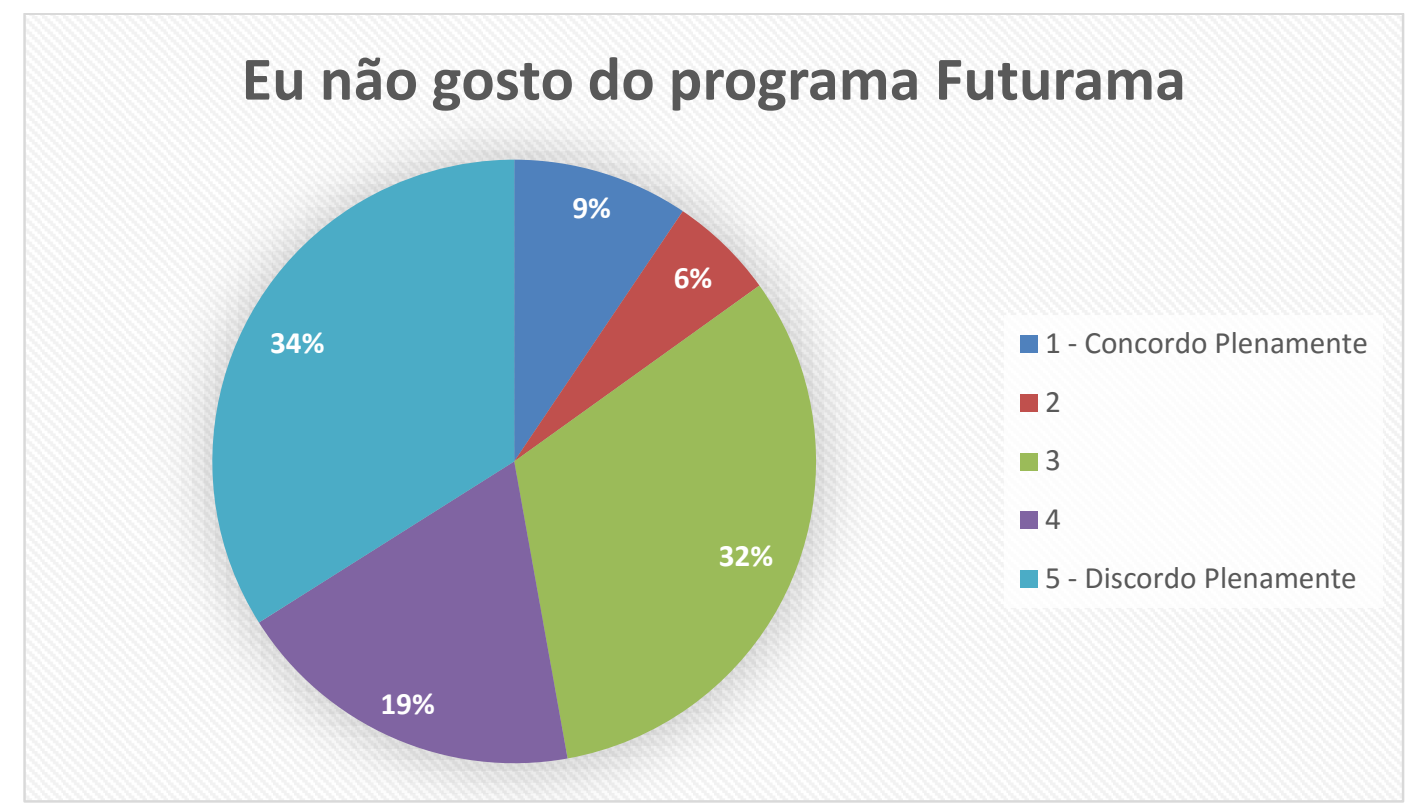

Fonte: Elaboração própria.

Os dados colhidos indicam que apenas 15\% dos estudantes assumiram não gostar desse programa, comprovando assim que Futurama é um desenho que os alunos pesquisados possuem interesse.

\subsection{ANÁLISE E DISCUSSÃO DO PÓS-QUESTIONÁRIO}

O pós-questionário foi aplicado a 51 alunos do 9ำ Ano do ensino fundamental que já haviam anteriormente respondido ao pré-questionário. Desta forma, a faixa etária permanece a mesma, entretanto, o número de alunos pesquisados (26 do sexo masculino e 25 do sexo feminino) foi alterado, pois, no dia da aplicação do pósquestionário, dois alunos haviam faltado à escola.

Também se manteve no pós-questionário o padrão dos dados colhidos no préquestionário, pois mais de $80 \%$ dos estudantes declararam possuir televisão a cabo neste questionário.

Com relação ao levantamento de dados, a primeira questão relacionada ao tópico do uso de desenhos como ferramenta de ensino foi "Quando vejo filmes e desenhos de ficção científica fico estimulado para entender a explicação de algumas cenas". Os dados coletados indicam que apenas 6\% dos alunos discordam totalmente da afirmativa, enquanto $59 \%$ deles declararam ficar estimulados para 
entender a explicação. Neste sentido, o gráfico 13 ilustra o grau de curiosidade que os alunos demonstram nas explicações das cenas.

GRÁFICO 13 - Quando vejo filmes e desenhos de ficção científica fico estimulado para entender a explicação de algumas cenas.

\section{Quando vejo filmes e desenhos de ficção científica fico estimulado para entender a explicação de algumas cenas.}

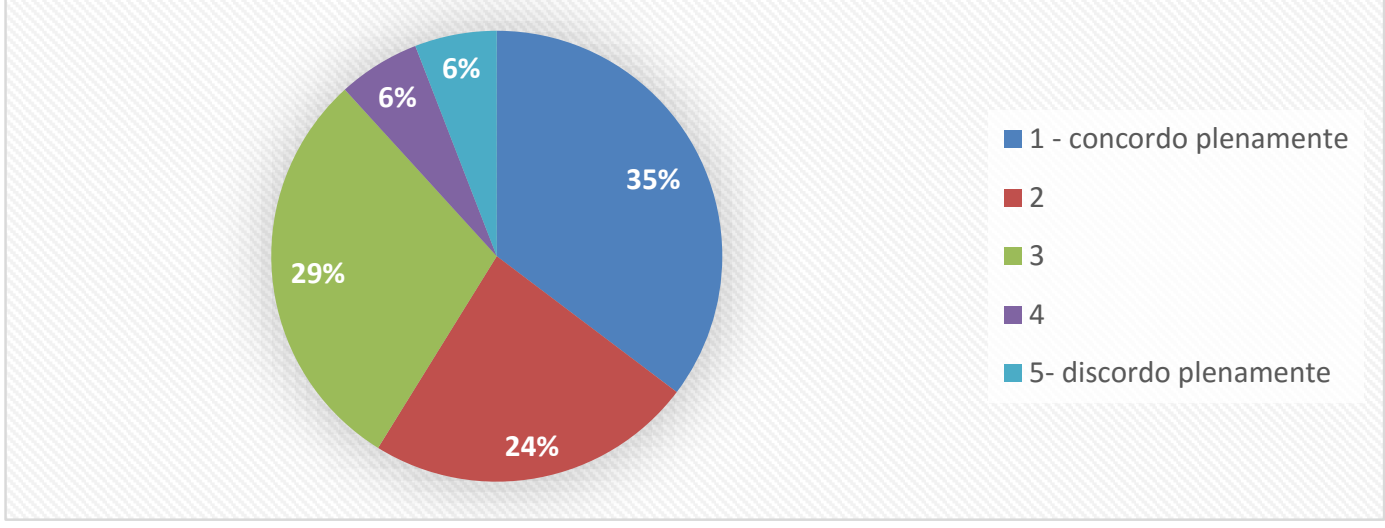

Fonte: Elaboração própria.

Os dados corroboram com a pesquisa, pois demonstram que a maioria dos alunos se mostra curioso ou estimulado pelo uso de desenhos animados ou filmes de ficção científica. Tal interesse vai ao encontro com a teoria de Ausubel, que determina que para a aprendizagem ocorrer, é necessário que o aluno esteja interessado no tema proposto.

Dentro deste ponto de vista, é necessário que o professor que decidir usar desenhos ou filmes em sua prática explique aos alunos os termos científicos previamente, de modo a promover a compreensão plena da cena. Assim, o aluno será capaz de aprender de forma significativa, pois entenderá a situação exibida no desenho ou filme. Além disso, o fato de usar os desenhos animados para ilustrar situações que nem sempre são fáceis de serem visualizadas cria um elo entre o estudante e a situação retratada. 
É importante que os estudantes pensem se o que ocorreu é ou não possível, pois esse é o primeiro passo para uma visão crítica de mundo, além de levar os alunos a pensar - que é o objetivo fundamental da educação.

A próxima questão a ser analisada do pós-questionário é "Diversos fenômenos do cotidiano podem ser explicados por meio da física". Tal pergunta revelou que $70 \%$ dos alunos concordam plenamente com a afirmação, e que apenas $2 \%$ discordam. O gráfico 14 a seguir demonstra que, de fato, a grande maioria dos sujeitos pesquisados defende esta questão.

GRÁFICO 14 - Diversos fenômenos do cotidiano podem ser explicados por meio da física.

\section{Diversos fenômenos do cotidiano podem ser explicados por meio da física} 0\%

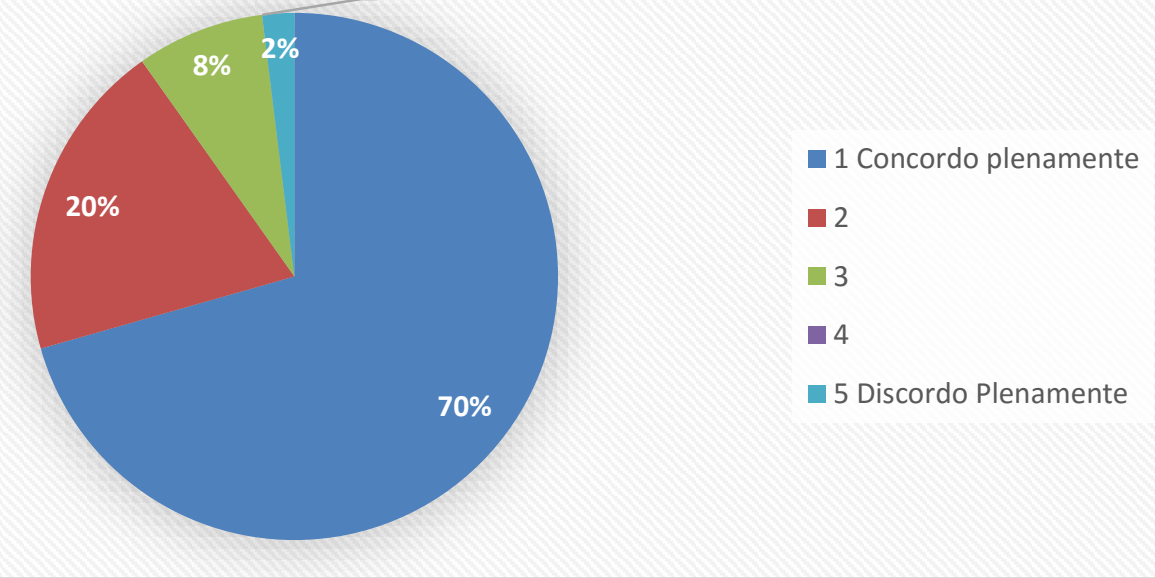

Fonte: Elaboração própria.

Este gráfico pode ser analisado de forma comparativa com o gráfico 05 , aplicado no pré-questionário, no qual $58 \%$ dos alunos declararam que a física explica o ambiente ao seu redor. No gráfico 14 , realizado no pós-questionário, nota-se aumento no número de alunos que acredita que diversos fenômenos do cotidiano podem ser explicados por meio da física - ou seja, acreditam que a física está presente no ambiente que os cerca.

Uma outra questão do pós-questionário relacionada à percepção da física no ambiente é "Eu nunca tinha percebido conceitos de física fora da sala de aula". Nesta pergunta, $57 \%$ dos alunos afirmam discordar plenamente e apenas $15 \%$ 
declarou concordar com esta afirmação. O gráfico 15 revela que o quantitativo de alunos que havia percebido conceitos de física chega a $73 \%$ dos sujeitos pesquisados.

GRÁFICO 15 - Eu nunca tinha percebido conceitos de física fora da sala de aula.

\section{Eu nunca tinha percebido conceitos de física fora da sala de aula.}

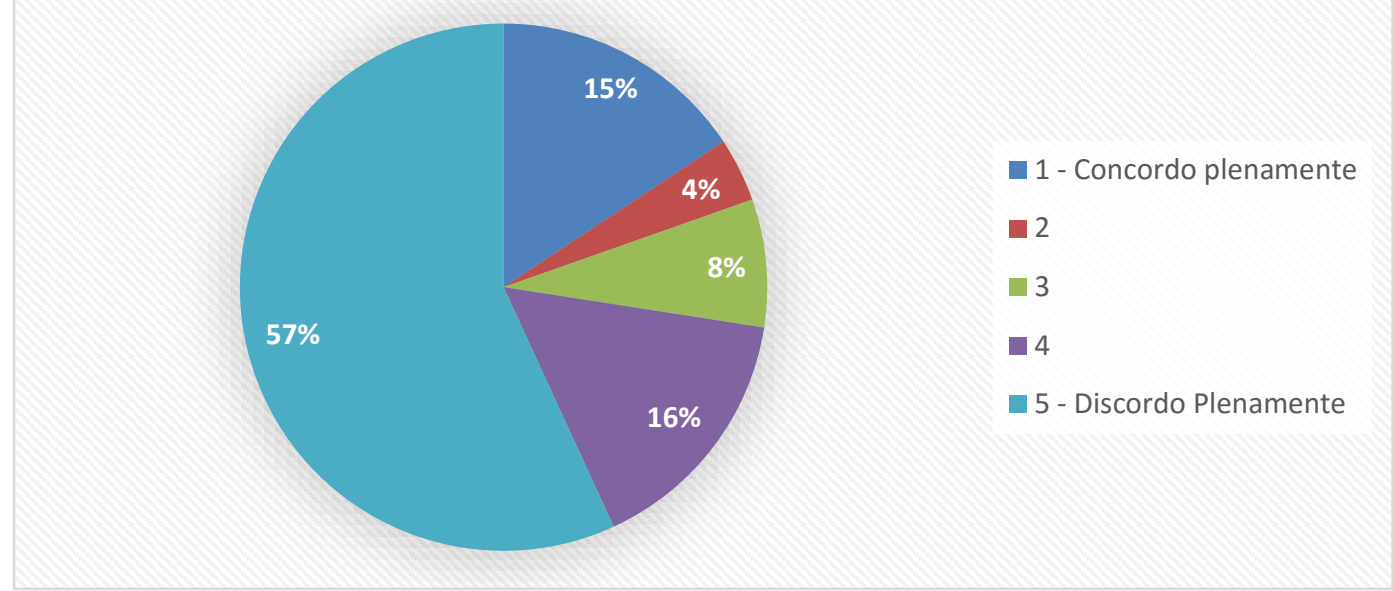

Fonte: Elaboração própria.

Apesar de nem todos os estudantes terem percebido fenômenos físicos fora da sala de aula e de nem todos os estudantes gostarem da disciplina, eles percebem que a física pode, de fato, explicar as situações de seu cotidiano.

Outra questão que merece atenção no pós-questionário é "Eu gosto de Física". Nota-se pelo gráfico 16 que o perfil dos alunos pesquisado mudou um pouco desde a aplicação do pré-questionário representado pelo gráfico 9 , pois inicialmente 9 estudantes afirmaram que não gostavam de física e, após o uso dos desenhos animados, 05 estudantes mantém a mesma opinião. O número de estudantes que afirmavam que gostavam muito de física inicialmente eram 15, e depois 17.

GRÁFICO 16 - Eu gosto de física. 


\section{Eu gosto de física}

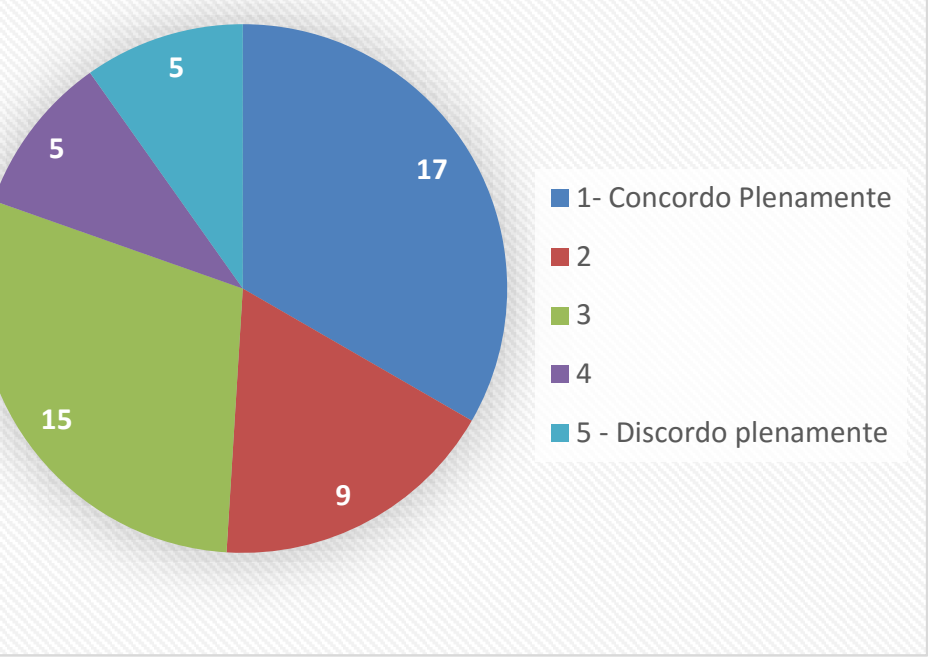

Fonte: Elaboração própria.

Os dados totais mostram que inicialmente 14 alunos não gostam de física (ao somar os dados correspondentes aos números 1 e 2 do gráfico 9) e os estudantes que após a aplicação do produto concordam com a ideia são 10 (ao somar os valores correspondentes aos números 4 e 5 do gráfico 16). Já os estudantes que afirmaram gostar de física no pré-teste somam um total de 24(ao somar os valores 4 e 5 do gráfico 9) e após a aplicação do produto o total de estudantes somam um total de 26(ao somar os valores correspondentes aos números 1 e 2) ${ }^{9}$.

Esses dados corroboram a ideia de que a utilização de desenhos animados em sala cria um vínculo com a disciplina. Tal vínculo é um fator de estímulo e motivação para que os alunos estudem mais a disciplina e se interessem mais por ela.

A próxima questão do pós-questionário é "Posso entender melhor o mundo ao conhecer os conceitos de física". Neste caso $62 \%$ dos alunos concordam com essa ideia.

GRÁFICO 17 - Posso entender melhor o mundo ao conhecer os conceitos de física.

\footnotetext{
${ }^{9}$ Cabe ressaltar que o total de estudantes do pós questionário é iguala 51 e do pré-questionário 53.
} 


\section{Posso entender melhor o mundo ao conhecer os conceitos de Física}

$10 \%$

\section{$4 \%$}

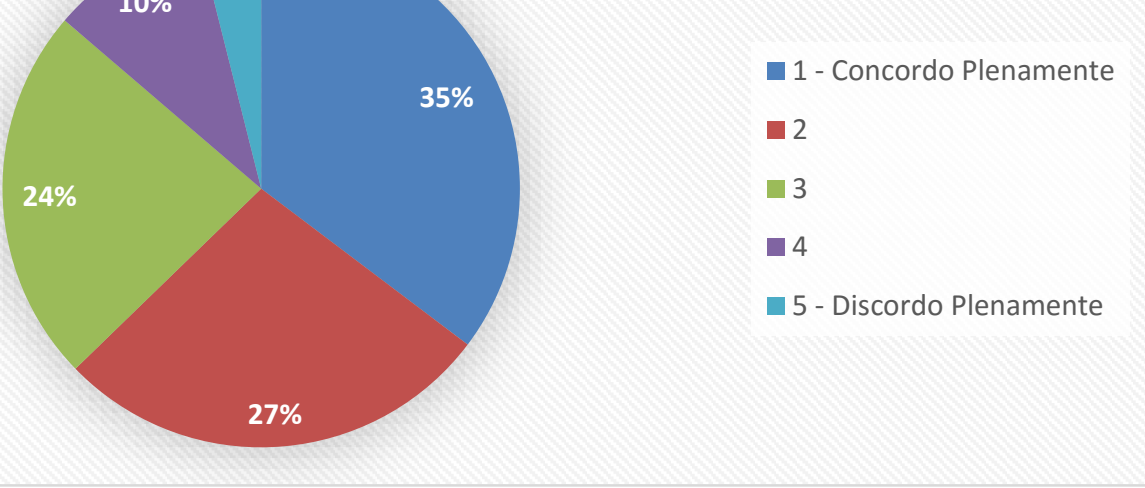

Fonte: Elaboração própria.

Os estudantes percebem que a Física explica o ambiente ao seu redor, independente de a entenderem ou não. Esta visão fica clara ao se comparar o gráfico 14 com o gráfico 17. Dessa maneira, conclui-se que os estudantes precisam de estímulos para perceber situações as quais a física explique. Uma ótima maneira de se obter tais situações faz-se presente na utilização de desenhos animados.

Os estudantes ainda foram questionados a respeito da maneira como consideram séries que possuem/citam fenômenos da natureza. Os estudantes discordaram de forma clara, pois apenas $4 \%$ concordam com essa ideia como é demonstrado no gráfico 18.

GRÁFICO 18 - Séries que citam e/ou contêm fenômenos da natureza são chatos. 


\section{Séries que citam e/ou contêm fenômenos da natureza são chatos.}

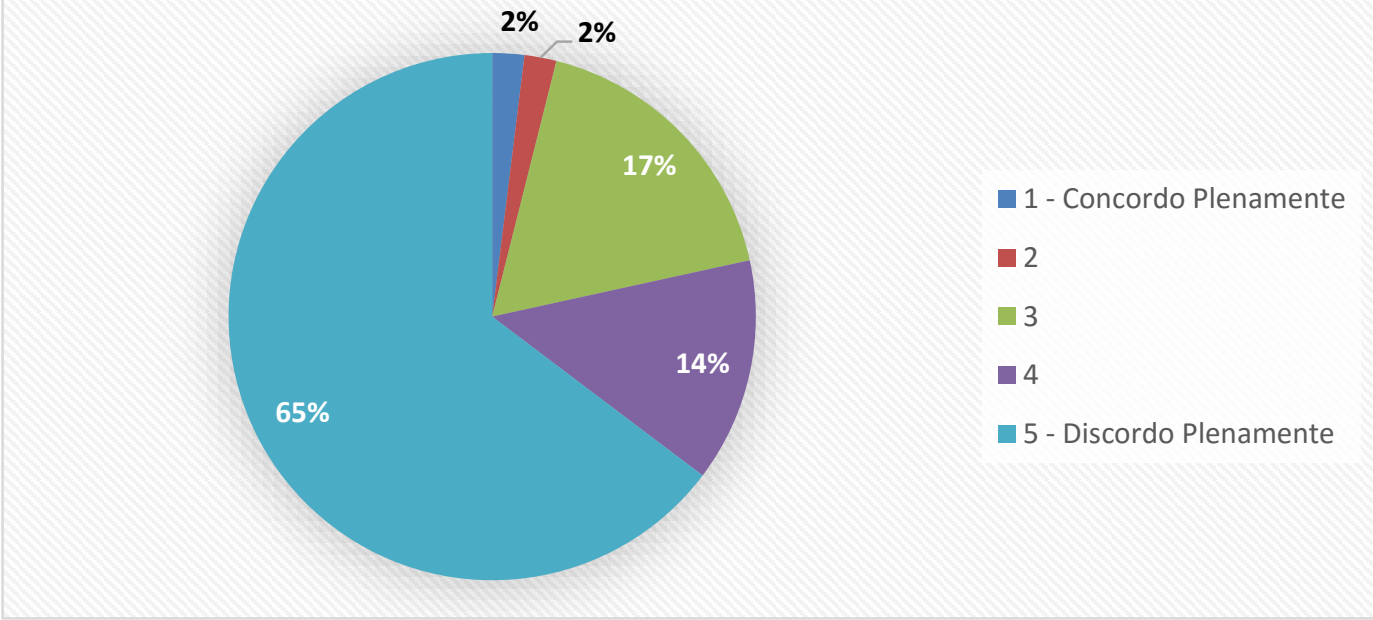

Fonte: Elaboração própria.

Pode-se assim inferir através dos dados do gráfico que, ao se utilizar desenhos ou séries com essa temática, os estudantes acabariam por ficar mais motivados, e que o presente projeto possui uma grande chance de aceitação por parte dos estudantes.

Por fim, os alunos foram questionados sobre terem se interessado mais por Futurama após terem visto trechos do desenho. Apesar de $8 \%$ declararem não ter interesse no desenho, a maioria dos estudantes (64\%) assumiram ter mais interesse pelo desenho, fato ilustrado pelo gráfico 19.

GRÁFICO 19 - Após ver os trechos de Futurama me interessei mais em assistir este desenho. 


\section{Após ver os trechos de Futurama me interessei assistir mais este desenho.}

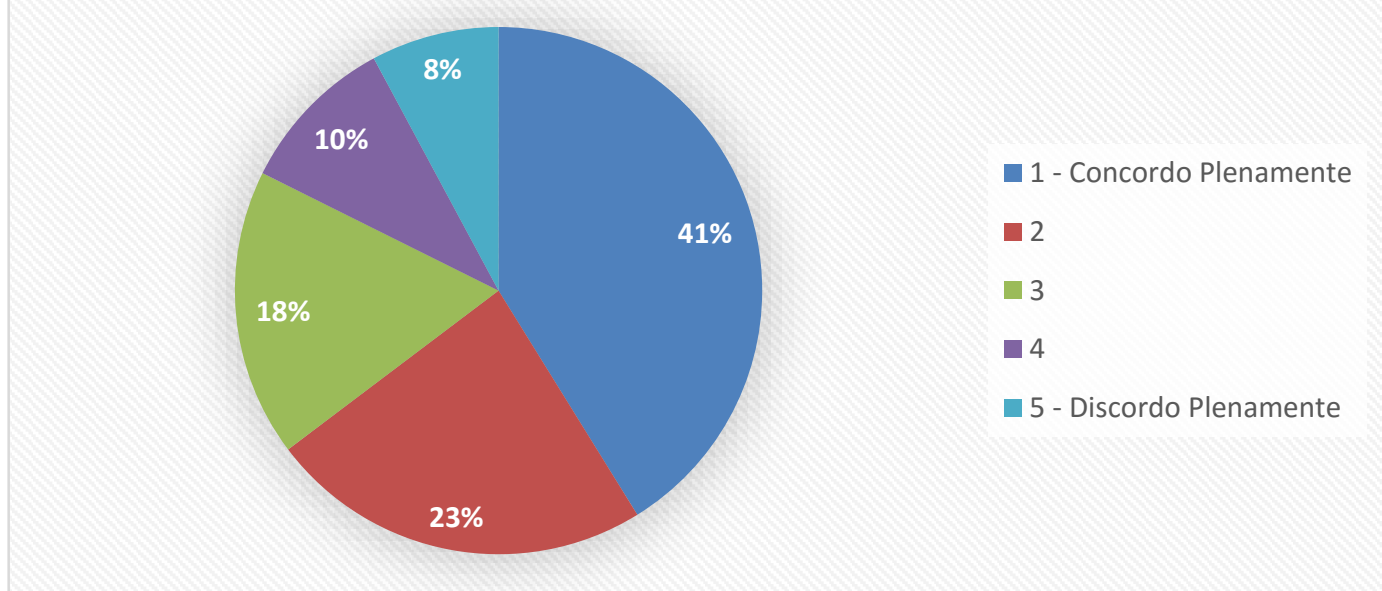

Fonte: Elaboração própria.

Tal interesse demonstra a curiosidade dos estudantes ao perceberem que possuem desenhos animados no próprio cotidiano que revelam conceitos científicos.

O pós-questionário encerra-se então com uma verificação da aprendizagem composta por 4 questões ${ }^{10}$. Assim, após assistirem a aula expositiva e os desenhos, tais questões foram propostas aos estudantes para poder fazer uma análise a respeito da aprendizagem em questão para todos os estudantes.

A primeira questão foi aplicada pelo ENEM PPL, que é o Exame Nacional do Ensino Médio para Pessoas Privadas de Liberdade. Nesta questão, o conceito de inércia é cobrado de forma sutil. Dos estudantes questionados, $66,7 \%$ acertaram a questão.

A segunda questão é de natureza discursiva e incita o debate sobre 0 conceito de inércia baseado em uma tirinha em quadrinhos. Nessa questão, 63\% dos estudantes responderam as de forma condizente com o que foi proposto.

A terceira pergunta refere-se quatro objetos que caem de um avião em movimento. Tal questão criou certa confusão entre os alunos, pois vários interpretaram que seria a trajetória a ser seguida durante a queda do avião, ao invés de como os objetos ficariam ao ser soltos. Assim, o índice de acerto da questão foi de $9,8 \%$ das marcações.

\footnotetext{
${ }^{10}$ Vide apêndice $B$.
} 
A quarta e última pergunta do pós-questionário inclui uma tirinha que trabalha com o conceito de inércia. Nesta última questão, o índice de acerto entre os alunos pesquisados foi de $88,2 \%$.

Assim, o desempenho dos estudantes nessas questões sugere que eles conseguiram, em sua maioria aprender e reconhecer o conceito de inércia, de forma autônoma e satisfatória. Dessa maneira o apelo visual do desenho conseguiu cumprir sua finalidade e, assim, pode se tornar ferramenta útil no âmbito escolar. Essa ferramenta despertou mais interesse dos estudantes, deixando-os mais motivados para estudar física.

\subsection{ANÁLISE E DISCUSSÃO DO QUESTIONÁRIO PÓS-TESTE}

O questionário pós-teste foi aplicado a 52 alunos do 9o Ano do ensino fundamental que já haviam anteriormente respondido ao pré-questionário e pós questionário. Desta forma, a faixa etária permanece, entretanto, o número de alunos pesquisados foi alterado, pois no dia da aplicação do questionário pós-teste, um aluno havia faltado à escola.

GRÁFICO 20 - Futurama me ajudou a compreender melhor o conceito de inércia? Como?

\section{Futurama me ajudou a compreender melhor o conceito de inércia? Como?}

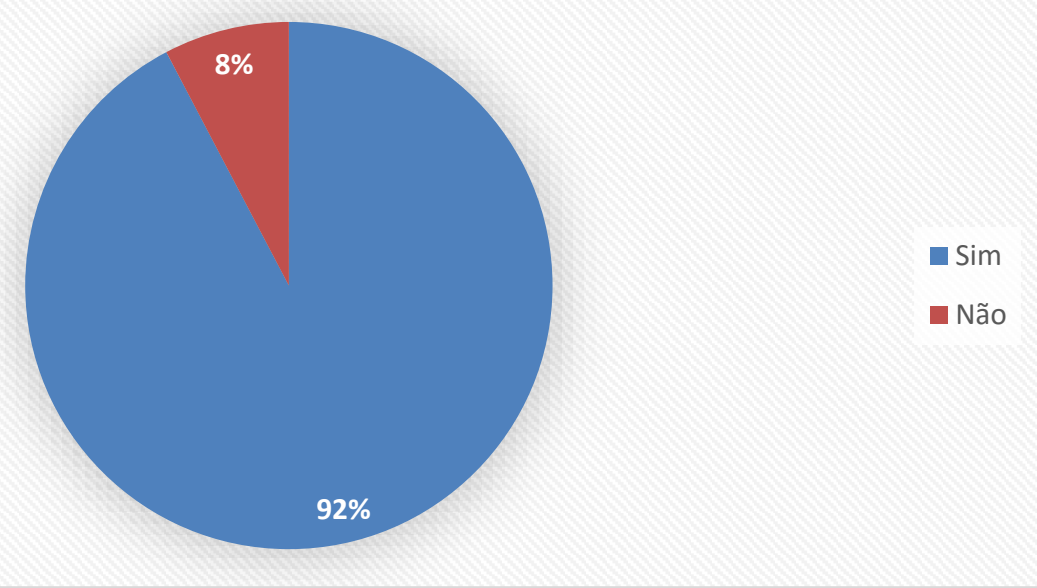

Fonte: Elaboração própria.

Tais dados confirmam a proposta da pesquisa uma vez que mostram que a maioria dos estudantes concordam que Futurama os ajudou a compreender, pois de 
acordo com relatos dos estudantes ficou mais fácil relacionar o tema inércia depois de assistirem ao desenho. Dos quatro estudantes que argumentaram que o desenho não os ajudou, dois pediram para utilizar outros desenhos, pois não gostam de Futurama. Os outros dois estudantes afirmaram que seria necessária uma apresentação prévia do conceito inércia pelo professor, de modo compreenderem e perceberem o conceito apresentado no desenho - ou seja, os alunos sugeriram uma alteração da sequência do plano de aula desenvolvido.

GRÁFICO 21 - Após assistir Futurama, consegui resolver as questões relacionadas à inércia com maior facilidade? Por quê?

\section{Após assistir Futurama, consegui resolver as questões relacionadas à inércia com maior facilidade? Por quê?}

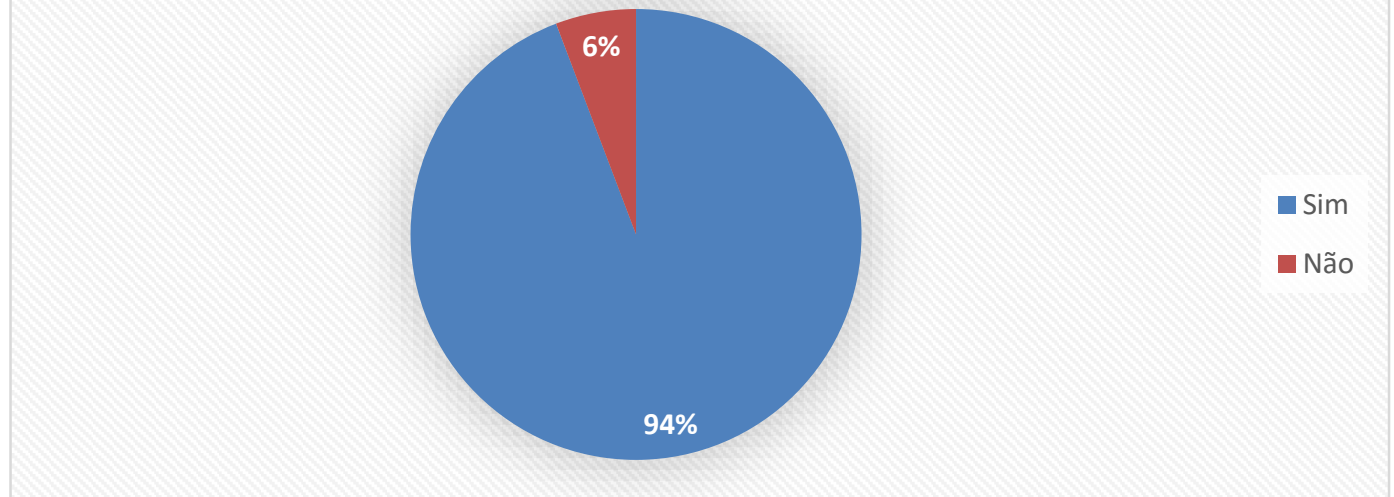

Fonte: Elaboração própria.

$\mathrm{Na}$ opinião dos estudantes, o desenho os ajudou a resolver as questões relacionadas a inércia com maior facilidade, pois $94 \%$ afirmaram isso no questionário pós-teste. Os três alunos que afirmaram que Futurama não os ajudou a resolver as questões representam $6 \%$ dos alunos pesquisados. Suas justificativas para afirmar que o desenho animado não os ajudou estão dispostas a seguir:

Aluno 1: "o gráfico do desenho é horrível"

Aluno 2: "o desenho não ajudou a compreender o conceito, logo não ajudou a resolver as questões"

Aluno 3: "Não ajudou pois não são apresentados os conceitos. " 
Os comentários a favor do projeto de alguns estudantes são apresentados a seguir:

Aluno 4: "Sim, pois entendemos a matéria de uma forma divertida, onde nunca paramos para perceber a física no nosso ambiente".

Aluno 5: "Sim, pois compreendia melhor o funcionamento desta e me ajudou a visualizar o que aconteceria nas questões propostas"

A terceira questão solicita dos estudantes sua opinião sobre ter aulas ilustradas com desenhos animados. Apenas um estudante argumentou que consiste em uma técnica de entretenimento, o que permite concluir que isso não interessa a ele. Os demais argumentaram mais a favor, pois acharam uma forma de facilitar o entendimento do conceito de inércia. Algumas opiniões dos alunos sobre ter aulas ilustradas com desenhos animados estão dispostas a seguir.

Aluno 6: "Muito boa, deixa a aula mais interessante".

Aluno 7: "Diferente, pois nos faz entender de um modo fácil e até legal, faz física ficar fácil"

Aluno 8: "Acho legal e diferente, é um bom modo de ver que podemos aprender até em animações, filmes, jogos e não só em livros".

Aluno 9: "É uma nova maneira de dar aula. Sair da rotina todo dia. Mas é muito legal e acho que outras matérias deveriam adotar essa nova maneira de ensinar. Complementando a matéria dos livros".

Aluno 10: "Acho que ajuda bastante e faz o aluno se empenhar na matéria, por ser uma forma diferente de aprender".

Com tais comentários e $98 \%$ dos estudantes apoiando o projeto de uso de desenhos animados, podemos concluir que a utilização de Futurama é algo que ajuda os estudantes a se empenharem na matéria e, assim, acabam por ter uma aprendizagem com prazer, o que torna a ideia do projeto muito aplicável em outros momentos.

A última questão consiste em deixar um comentário a respeito do projeto. Apenas um estudante não respondeu a essa questão. Os demais estudantes em sua totalidade apoiam o projeto. Algumas opiniões dos alunos a respeito do projeto são dispostas a seguir. 
Aluno 11: "O projeto é muito legal e deveria ser usado nas matérias, pois eu, como aluna digo que gosto muito mais de aprender com medidas alternativas como essa".

Aluno 12: "Considero este projeto uma boa iniciativa, pois incentiva e anima os alunos a aprender física".

Aluno 13: "Eu gosto a experiência e acredito que me ajudou bastante. Gostaria que fosse repetido se der".

Aluno 14: "É um projeto interessante, pois até nas coisas mais simples, como um desenho animado, a física se aplica. Fazendo com que fique fácil, ou facilite, entender alguns conceitos de física".

Aluno 15: "Achei um ótimo projeto, e que deveria acontecer mais vezes no ano, pois é um modo legal e descontraído de fugir da rotina, mas ainda sim aprendendo".

Aluno 16: "Muito interessante. Pois os alunos estão "cansados" sobre ficar 6 horários durante a semana só com o livro. $\mathrm{O}$ desenho animado durante as aulas, nos faz perceber que um dia, essa matéria que aprendemos e "achamos um pouco chata" possa ser útil. Para o dia a dia e a compreensão de alguns desenhos".

Aluno 17: "Eu tenho muita dificuldade em física e quando o professor mostrou o conceito em prática no desenho, a compreensão da matéria foi melhor".

Com tais comentários, esse projeto confirma sua proposta, que é de deixar os estudantes mais motivados e interessados em a física, mostrando, dessa maneira, que ao utilizar os desenhos animados estamos deixando os alunos mais motivados a estudar, se empenhar, pois estão aprendendo de maneira não-usual. Dessa maneira, conclui-se que o projeto é bom na concepção dos alunos, estes estão interessados e que o produto é potencialmente significativo, podendo ser utilizado em mais situações, não apenas de inércia, uma vez que os desenhos permitem uma abordagem muito ampla. 


\section{CONSIDERAÇÕES FINAIS E PERSPECTIVAS}

O uso de desenhos animados é considerado nesta pesquisa como uma ferramenta para o ensino da primeira lei de Newton para alunos do $9^{\circ}$ ano do ensino fundamental. Foi a partir desta premissa que foi criado o produto educacional que consiste em uma cartilha e oito trechos de oito episódios distintos do desenho animado Futurama, nos quais são mostradas cenas com forte apelo visual para que os estudantes possam perceber o conceito de inércia.

O intuito da utilização deste instrumento é mostrar aos estudantes que a disciplina física está totalmente relacionada com a própria realidade por eles vivida, além de mostrar para os estudantes que eles podem aprender física em várias situações, inclusive assistindo desenhos animados. Assim, buscou-se criar um produto que despertasse os estudantes para as áreas científicas, relacionando o estudo da física a uma ferramenta lúdica.

A pesquisa mostra um impacto positivo da utilização de desenhos animados no ensino de física. Isto se deve à contextualização de princípios físicos nas situações apresentadas nos desenhos, no caso Futurama, além da linguagem informal utilizada pelos personagens do desenho, que se aproxima daquela utilizada pelos estudantes. Isto vai ao encontro da teoria de Vygotsky, que defende que não se pode falar em desenvolvimento sem levar em consideração o contexto históricosocial dos indivíduos.

O sucesso do uso do desenho animado Futurama pode ser comprovado pelos dados da pesquisa, em especial pelo aumento do número de alunos que declararam gostar da disciplina física. Dessa forma, os desenhos animados cumpriram a função de despertar o interesse para a física, pois o número de alunos que declararam querer assistir mais episódios de Futurama foi significativo. Ou seja, o desenho serviu como fonte de motivação para os alunos, fato que, na teoria de Ausubel, constitui a força motriz do processo educacional e cabe ao professor conseguir selecionar objetos que fomentem estimulem e motivem seus alunos.

$\mathrm{Na}$ pesquisa, os estudantes relatam que se sentem estimulados a entender a explicação de cenas em desenhos e filmes de ficção científica, pois ao assistir tais cenas, gostariam de saber como determinada situação é possível. Isso é importante, 
pois as dúvidas referentes a determinada cena motivam os estudantes a pesquisar a respeito do assunto e a desenvolver um senso crítico.

Com os resultados obtidos ao utilizar Futurama como ferramenta de ensino, pretende-se aprimorar a utilização de desenhos e séries como instrumento na explicação de conceitos físicos, de modo a serem aplicados em todas as séries que possuam o componente curricular física. 


\section{BIBLIOGRAFIA}

ALBAGLI, S. Divulgação científica: informação científica para cidadania. Ciência da informação, v. 25, n. 3, 1996.

ALVES, R. A escola que sempre sonhei sem imaginar que pudesse existir. CampinasSP. Editora Papirus. 2001

American Academy of Pediatrics. Children, adolescents and television. Pediatrics Vol 107: p. 423-26, 02 de fevereiro de 2001.

Anônimo. TV por assinatura está disponível para 57,66 milhões de brasileiros. Disponível em:

http://www.anatel.gov.br/Portal/exibirPortalNoticias.do?acao=carregaNoticia\&codigo $=32513$ Acessado em 21 de junho de 2014.

AUSUBEL, D.P. A aprendizagem significativa: a teoria de David Ausubel. São Paulo: Moraes, 1982.

BORDENAVE, J.D. e PEREIRA, A.M. Estratégias de ensino -aprendizagem. 20. ed. Petrópolis: Vozes, 1999.

BRASIL. MINISTÉRIO DA EDUCAÇÃO. Secretaria de Educação Média e Tecnológica. Parâmetros Curriculares Nacionais: Ensino Médio (PCNEM). Brasília: MEC/SEMTEC, 4v - p.123-199, 1999.

BRUNER, J. O Processo da educação, Edições 70, Lisboa, 1998

CHASSOT, A. Alfabetização científica: uma possibilidade para a inclusão social. Associação Nacional de Pós-Graduação e Pesquisa em Educação, 2006.

FARADAY, M. A história química de uma vela: As forças da matéria. Trad. Vera Ribeiro. Rio de Janeiro: Contraponto 2003.

FOUREZ, G. (2003). Crise no ensino de ciências? (Crisis in science teaching?). Investigações em ensino de ciências, 8(2) 2003, 109-123.

FRANCISCO, R. H.P. A divulgação científica. Revista Eletrônica de Ciências. v. 29, 2005. 
GASPAR, A. Museus e centros de ciências conceituação e proposta de um referencial teórico. São Paulo 1993. 173 f., tese de doutorado em educação - Faculdade de Educação, Universidade de São Paulo.

GOMEZ, Christopher. "Teaching physical geography at university with cartoons and comic strips: Motivation, construction and usage. New Zealand Geographer 70.2 (2014): 140-145.

GOMIDE, P. Crianças e adolescentes em frente à Tv: o que e quanto assistem de televisão

GONÇALVES, R.; MACHADO, D.M. Comics: investigación de conceptos y de términos paleontológicos, y uso como recurso didáctico em la educación primaria. Enseñanza de las Ciências, Barcelona, v. 23, n. 2, p. 263-274, 2005.

IBALDO, A. P., ANDRADE, V. C., GARG, R., MENEZES, P. Jr, SCHWANTES, C., SANTANA, A. E., Atracting girls and Young women from Distrito Federal (DF, Brazil) to pursue a carreer in Physics: first studies".. In: 6th Gender Summit (Book of Abstracts). 2015.

JACOBUCCI, D. F. C. Contribuição dos espaços não-formais de educação para a formação da cultura científica. Em extensão, Uberlânda, v.7, 2008.

JUNIOR, E. N. A imagem. São Paulo. Ática: 1986. PARANÁ, SECRETARIA DE ESTADO DA EDUCAÇÃO/SEED.

KAKALIOS, J, The Physics of the superheroes, Gotham Books, p. 21-32, 2005.

LUIZ, L. C; OLIVEIRA, L. F. Ensino de Física Radiológica e Radioproteção através do Lúdico. Disponível em www.conter.gov.br, acessado em 18/12/2014.

MAGALHÃES, C. E. R.; SILVA, E. F. G.; GONÇALVES, C. B. A interface entre alfabetização científica e divulgação científica. Revista Areté: Revista Amazônica de Ensino de Ciências, v. 5, n. 09, 2014.

MARAFON, D. Jogos e brincadeiras, subsídios metodológicos no processo de desenvolvimento e da aquisição do conhecimento na educação infantil. EDUCERE, v. 9 n.1, p. 9048 - 9061, 2009. 
MASSARANI, L. Ciência e Público: caminhos da divulgação científica no Brasil. Rio de Janeiro: Casa da Ciência - Centro Cultural de Ciência e Tecnologia da Universidade Federal do Rio de Janeiro, 2002. 232 p.

MOREIRA, Marco Antônio. Metodologias de Pesquisa em Ensino. São Paulo: Editora Livraria da Física, 2011.

MOREIRA, M. A. A teoria da mediação de Vygotsky. In: MOREIRA, M. A. Teorias de Aprendizagem. p 109 - 122. São Paulo: EPU, 1999.

MOREIRA, M.A. O que é aprendizagem significativa? A aprendizagem significativa: a teoria e textos complementares. São Paulo: Livraria da Física, 2012.

MOREIRA, M.A; GRECA, I.M; PALMERO, M.L.R. Modelos mentales y modelos comceptuales en la enseñanza/aprendizaje de las Ciencias. Revista Brasileira de Pesquisa em Educação em Ciências. 2, 3, (2002) 36-56.

MOREIRA, M. A. Ensino de Física no Brasil: retrospectiva e perspectivas. Revista brasileira de ensino de física. São Paulo. Vol. 22, n. 1 (mar. 2000), p. 94-99, 2000.

PERSECHINI, P. M. e CAVALCANTI, C. B. Museus de ciências e a popularização do conhecimento no Brasil, disponível em: https://factsreports.revues.org/1085 acesso em 23 de setembro de 2015.

POLITO, A. M. M. Galileu, Descartes e uma breve história do Princípio de Inércia. Revista do IFD, Brasília-DF, 2015.

PORTELA, S. I. C. A formação inicial de professores e a cultura científica na educação básica: problematizando a prática docente na interface das disciplinas Estágio Supervisionado e História da Física, 2014, 263 fls. Dissertação (Mestrado em Ensino de Física). Faculdade de Ciências da Universidade Estadual Paulista, Bauru, 2014.

RAMOS, P. A leitura dos quadrinhos. São Paulo: Contexto, 2009.

Retalis, S., Vassilikopoulou, M., Georgiakakis, P., \& Boloudakis, M. Comics in Education. Disponível em: http://www.educomics.org/ Acessado em 12 de agosto de 2015

Rogers, Michael. An inquiry-based course using "physics?" in cartoons and movies. The Physics Teacher 45.1 (2007): 38-41. 
REZENDE, Luiz Augusto. História das ciências no ensino de ciências: contribuições dos recursos audiovisuais. Ciências em Tela (2008): 1-7.

REZENDE, Luiz Augusto C., Marcus Vinicius Pereira, and Alexandre C. VAIRO. Recursos Audiovisuais como temática de pesquisa em periódicos brasileiros de Educação em Ciências. Revista Brasileira de Pesquisa em Educação em Ciências 11.2 (2011): 183-204.

RIBEIRO, E. A. A perspectiva da entrevista na investigação qualitativa. Evidência: olhares e pesquisa em saberes educacionais, Araxá/MG, n. 04, p.129-148, maio de 2008. ROLOFF, E. M. (s.d.). A Importância Do Lúdico Em Sala De Aula. Disponível em: http://ebooks.pucrs.br/edipucrs/anais/Xsemanadeletras/comunicacoes/Eleana-Margarete-

Roloff.pdf Acesso em 05 de agosto de 2015

SANT' ANNA, A. e NASCIMENTO, P. R. A história do lúdico na educação, REVEMAT, v. 06, n.2, p. 19-36, 2011.

SARTORI, A.F. ; EMF RAMOS. Ferramentas audiovisuais como instrumento no ensino de física. Simpósio Nacional de Ensino de Física, XVII (2007).

SASSERON, Lúcia Helena; CARVALHO, Anna Maria Pessoa de. Alfabetização científica: uma revisão bibliográfica. Investigaçoes em ensino de ciências, v. 16, n. 1, p. 59-77, 2011.

SILVA, S. A. Os animês e o ensino de ciências. 2011. 212 f., il. Dissertação (Mestrado em Ensino de Ciências) Universidade de Brasília, Brasília, 2011.

SILVA, A. M.; MARSYL, B. M.; e Márcia Simão Linhares Barreto. O lúdico no processo de ensino-aprendizagem das ciências. Revista Brasileira de Estudos Pedagógicos 88.220 (2007): 445-458.

SILVA, H. C. O que é divulgação científica? Revista Ciência \& Ensino, vol 1, n. 1, p. 57$58,2006$.

SILVA, J. Silva e J. Souza, 0 ensino de Física em Botucatu, Revista Botucatuense de Ensino de Física, v. 97, n. 4, p. 1103-1125, 2010.

TESTONI, L.A. Um corpo que cai: As Histórias em Quadrinhos no Ensino de Física, 2004, 158 fls. Dissertação (Mestrado em Educação). Faculdade de Educação da Universidade de São Paulo, São Paulo, 2004. 
TESTONI, L.A.; ABIB, M.L.V.S. A utilização de histórias em quadrinhos no ensino de física: uma proposta para o ensino de inércia. Enseñanza de las Ciencias, Granada, v. extra, p.15, 2005.

UTGES, G.R. Modelos e analogias na compreensão do conceito de onda. Universidade de São Paulo. Tese (Doutorado em Educação), 1999.

VÍLCHEZ-GONZÁLEZ, J.M; PERALES-PALACIOS, F. J. Image of science in cartoons and its relationship with the image in comics. Physics Education, v. 41, p.240-249, 2006.

VYGOTSKY, L.S.. A formação social da mente. $2^{\underline{a}}$ edição. São Paulo, Editora Martins Fontes.

WOHLGEMUTH, Julio. Vídeo Educativo: uma pedagogia audiovisual. Brasília: Senac, 2005.

WORNER, C.H; ROMERO, A. Una maneira diferente de enseñar física: Física y humor. Enseñanza de las Ciências, Barcelona, v. 16, n. 1, p. 187-192, 1998.

XAVIER, M., Bielemann, R., Maciel, F., Neutzling, M., Gigante, D. Revista Brasileira de Atividade física \& Saúde v. 19, p. 74-85, 2014 


\section{APÊNDICE A \\ Pré-questionário}

\section{Pesquisa sobre percepção de Física de Alunos do 9o Ano do Ensino Fundamental.}

O presente questionário é parte da pesquisa do projeto de Dissertação de Mestrado "Ensino de Física no 9o Ano do Ensino fundamental II com desenhos animados uma abordagem lúdica do conceito de inércia - DF", realizado por Diego Veríssimo Pereira, aluno de mestrado do Programa MNPEF-UnB, e por Dra. Adriana Pereira Ibaldo, professora adjunto II do IF-UnB.

O questionário é composto por duas partes: a primeira parte trata-se de um questionário de perfil do respondente, na qual são solicitadas informações sobre faixa etária, nível educacional, contexto sócio-econômico e cultural. A segunda parte é composta por perguntas sobre sua experiência particular com relação aos seus estudos em Física. Experiências anteriores com Ciências Físicas e Biológicas (CFB) também podem ser levadas em consideração. As perguntas 11, 14, 15, 16, 18, 20,21, 27, 28, 29 e 30 foram retiradas do trabalho "Atracting girls and Young women from Distrito Federal (DF, Brazil) to pursue a carreer in Physics: first studies" (IBALDO, 2015) pois se aplicavam ao contexto do presente trabalho.

Em ambas as partes deste questionário solicitamos a gentileza de não incluir dados pessoais como nome completo, documentos (RG, CPF, RNE), e dados para contato (telefones, endereço, e-mails e outras mídias sociais, como Facebook, Twitter, Tumblr, etc). O presente questionário é anônimo.

Os realizadores do presente questionário agradecem a sua participação.

1. Qual é o seu sexo?
- Masculino
- Feminino

2. Qual é a sua idade?
- até 13 anos
- 14 anos
- 15 anos
- 16 anos
- 17 anos ou mais 
3. Você possui Tv a cabo em casa?
- Sim
○ Não

4. Quantas horas diárias você assiste televisão?
$\circ$ entre 0 e 1
$\circ$ entre 1 e 2
- entre 2 e 3
- entre 3 e 4
- mais que 4

5. Quais os canais você MAIS assiste?
- Globo, Record, Band ou SBT
- Discovery Kids
○ Fox
- History
- Telecine
- Animal Planet
- Outro:

6. Qual o tipo de programa você mais assiste?
- Séries
- Esportes
- Desenhos
- Noticiários
- Outro:

7. Você assiste programas de cunho científico?
- Sim
○ Não

8. Eu gosto de desenhos animados:

$\left.\begin{array}{llllll}1 & 2 & 3 & 4 & 5\end{array}\right]$

9. Se você assiste desenhos, quais você assiste?

- Cite os nomes 
10. A Física consiste apenas em aplicar fórmulas matemáticas.

\begin{tabular}{lllllll}
1 & 2 & 3 & 4 & 5 & \\
\hline Concordo Plenamente $\bigcirc$ & $\bigcirc$ & $\bigcirc$ & $\bigcirc$ & Discordo Plenamente
\end{tabular}

11. Eu acho que os conceitos estudados em Física são inúteis para a minha vida. ${ }^{*}$

$\begin{array}{lllll}1 & 2 & 3 & 4 & 5\end{array}$

Concordo Plenamente $\bigcirc \bigcirc \bigcirc \bigcirc$ Discordo Plenamente

12. Eu acho física é uma disciplina muito difícil.

$\begin{array}{lllllll}1 & 2 & 3 & 4 & 5\end{array}$

13. Eu gosto de matemática.

$\begin{array}{lllllll}1 & 2 & 3 & 4 & 5\end{array}$

14. Tenho facilidade para aprender Física e Matemática.*

$\begin{array}{lllll}1 & 2 & 3 & 4 & 5\end{array}$

Concordo Plenamente $\bigcirc \bigcirc \bigcirc$ Discordo Plenamente

15. Os conceitos de física apresentados em livros não tem aplicação no dia-adia. ${ }^{*}$

$\begin{array}{lllll}1 & 2 & 3 & 4 & 5\end{array}$

Concordo Plenamente $\bigcirc \bigcirc \bigcirc \bigcirc$ Discordo Plenamente

16. Os conceitos de física são muito importantes para o desenvolvimento tecnológico.*

$\begin{array}{lllll}1 & 2 & 3 & 4 & 5\end{array}$

Concordo Plenamente $\bigcirc \bigcirc \bigcirc$ Discordo Plenamente 
17. A física não explica o ambiente ao meu redor.

$\begin{array}{lllll}1 & 2 & 3 & 4 & 5\end{array}$

Concordo Plenamente $\bigcirc \bigcirc \bigcirc$ Discordo Plenamente

18. Já percebi algum fenômeno no dia-a-dia que pode ser explicado por algum conceito de física. *
○ Sim
○ Não

19.É mais fácil aprender uma matéria cujo professor a turma gosta.

\begin{tabular}{llllll}
1 & 2 & 3 & 4 & 5 \\
\hline Concordo Plenamente $\bigcirc$ & $\bigcirc$ & $\bigcirc$ & $\bigcirc$ & Discordo Plenamente
\end{tabular}

20. Quando tento resolver problemas de Física acho fácil compreender o que está sendo pedido.*

$\begin{array}{lllll}1 & 2 & 3 & 4 & 5\end{array}$

Concordo Plenamente $\bigcirc \odot \bigcirc \bigcirc$ Discordo Plenamente

21. Eu não gosto de física. *

$\begin{array}{lllll}1 & 2 & 3 & 4 & 5\end{array}$

Concordo Plenamente $\bigcirc \bigcirc \bigcirc$ Discordo Plenamente

22. Em algum desenho animado você já percebeu os conceitos de física?

○ Não

- Sim. Qual

23. Eu não gosto de física pois não gosto de matemática.

$\begin{array}{lllll}1 & 2 & 3 & 4 & 5\end{array}$

Concordo Plenamente $\bigcirc \bigcirc \bigcirc$ Discordo Plenamente 
24. Os programas de TV com temática em Ciência são entediantes.

$$
\begin{array}{lllllll}
1 & 2 & 3 & 4 & 5 & \\
\hline \text { Concordo Plenamente } \bigcirc & \bigcirc & \bigcirc & \bigcirc & \bigcirc & \text { Discordo Plenamente }
\end{array}
$$

25. Você conhece o desenho Futurama?
○ Sim
○ Não

26. Eu não gosto do programa Futurama.

$\begin{array}{lllllll}1 & 2 & 3 & 4 & 5 \\ \text { Concordo Plenamente } \bigcirc & \bigcirc & \bigcirc & \bigcirc \text { Discordo Plenamente }\end{array}$

27. Quando estou resolvendo problemas de Física não vejo relação com o que foi visto na aula e/ou livro-texto.*

$\begin{array}{lllll}1 & 2 & 3 & 4 & 5\end{array}$

Concordo Plenamente $\bigcirc \bigcirc \bigcirc \bigcirc$ Discordo Plenamente

28. A qual classe social sua família se encontra?*

A classificação abaixo está listada de acordo com a classificação do IBGE/FGV (Instituto Brasileiro de Geografia e Estatística/ Fundação Getúlio Vargas), dados de 2014.

- Classe $E$ - renda até $R \$ 1.085,00$

- Classe D - renda entre $R \$ 1.085,00$ a $R \$ 1.734,00$

- Classe C - renda entre $R \$ 1.734,00$ a $R \$ 7.475,00$

- Classe $B$ - renda entre $R \$ 7.475,00$ a $R \$ 9.745,00$

- Classe A - renda acima de $R \$ 9.745,00$

- Não sei - não desejo informar

29. Qual a profissão do seu Pai? *

30. Qual a profissão da sua Mãe? * 


\section{Apêndice $B$}

\section{Pós-Questionário}

\section{Exercícios de Verificação da Aprendizagem.}

O presente questionário é parte da pesquisa do projeto de Dissertação de Mestrado "Ensino de Física no 9o Ano do Ensino fundamental II com desenhos animados uma abordagem lúdica do conceito de inércia - DF", realizado por Diego Veríssimo Pereira, aluno de mestrado do Programa MNPEF-UnB, e por Dra. Adriana Pereira Ibaldo, professora adjunto II do IF-UnB.

O questionário é composto por duas partes: a primeira parte trata-se de um questionário de perfil do respondente, na qual são solicitadas informações sobre faixa etária, nível educacional, contexto sócio-econômico e cultural. A segunda parte é composta por perguntas sobre sua experiência particular com relação aos seus estudos em Física. Experiências anteriores com Ciências Físicas e Biológicas (CFB) também podem ser levadas em consideração.

Em ambas as partes deste questionário solicitamos a gentileza de não incluir dados pessoais como nome completo, documentos (RG, CPF, RNE), e dados para contato (telefones, endereço, e-mails e outras mídias sociais, como Facebook, Twitter, Tumblr, etc). O presente questionário é anônimo.

Os realizadores do presente questionário agradecem a sua participação.

1. Qual é o seu sexo?

- Masculino

- Feminino

2. Qual é a sua idade?
- até 13 anos
- 14 anos
- 15 anos
- 16 anos
- 17 anos ou mais

3. Você possui Tv a cabo em casa?
- Sim
○ Não 
4. Quando vejo filmes e desenhos de ficção científica fico estimulado para entender a explicação de algumas cenas.

$\begin{array}{lllll}1 & 2 & 3 & 4 & 5\end{array}$

Concordo Plenamente $\bigcirc \bigcirc \bigcirc$ Discordo Plenamente

5. Diversos fenômenos do cotidiano podem ser explicados por meio da Física.

$\begin{array}{lllll}1 & 2 & 3 & 4 & 5\end{array}$

Concordo Plenamente $\bigcirc \bigcirc \bigcirc$ Discordo Plenamente

6. Eu nunca tinha percebido nenhum conceito de física fora da sala de aula.

$\begin{array}{lllll}1 & 2 & 3 & 4 & 5\end{array}$

Concordo Plenamente $\bigcirc \bigcirc$ Discordo Plenamente

7. Eu gosto de Física.

$\begin{array}{lllll}1 & 2 & 3 & 4 & 5\end{array}$

Concordo Plenamente $\bigcirc \bigcirc \bigcirc$ Discordo Plenamente

8. Posso entender o mundo melhor ao conhecer os conceitos de Física.

$\begin{array}{lllll}1 & 2 & 3 & 4 & 5\end{array}$

Concordo Plenamente $\bigcirc \bigcirc \bigcirc$ Discordo Plenamente

9. Após ver os trechos de Futurama me interessei em ver mais deste desenho.

$\begin{array}{lllll}1 & 2 & 3 & 4 & 5\end{array}$

Concordo Plenamente $\bigcirc \bigcirc \bigcirc \bigcirc$ Discordo Plenamente

10. Séries que citam e/ou contém fenômenos da natureza são chatos.

$\begin{array}{lllll}1 & 2 & 3 & 4 & 5\end{array}$

Concordo Plenamente $\bigcirc \bigcirc \bigcirc$ Discordo Plenamente 
11. (Enem PPL 2012) Em 1543, Nicolau Copérnico publicou um livro revolucionário em que propunha a Terra girando em torno do seu próprio eixo e rodando em torno do Sol. Isso contraria a concepção aristotélica, que acredita que a Terra é o centro do universo. Para os aristotélicos, se a Terra gira do oeste para o leste, coisas como nuvens e pássaros, que não estão presas à Terra, pareceriam estar sempre se movendo do leste para o oeste, justamente como o Sol. Mas foi Galileu Galilei que, em 1632, baseando-se em experiências, rebateu a crítica aristotélica, confirmando assim o sistema de Copérnico. Seu argumento, adaptado para a nossa época, é se uma pessoa, dentro de um vagão de trem em repouso, solta uma bola, ela cai junto a seus pés. Mas se o vagão estiver se movendo com velocidade constante, a bola também cai junto a seus pés. Isto porque a bola, enquanto cai, continua a compartilhar do movimento do vagão. O princípio físico usado por Galileu para rebater o argumento aristotélico foi :
a) a lei da inércia.
b) a ação e reação.
c) a segunda lei de Newton.
d) a conservação da energia.
e) o princípio da equivalência.

12. Na tirinha de Jim Davis, exibida abaixo, Garfield acionou um freio. Baseado nos conceitos de física, explique o que ocorreu.

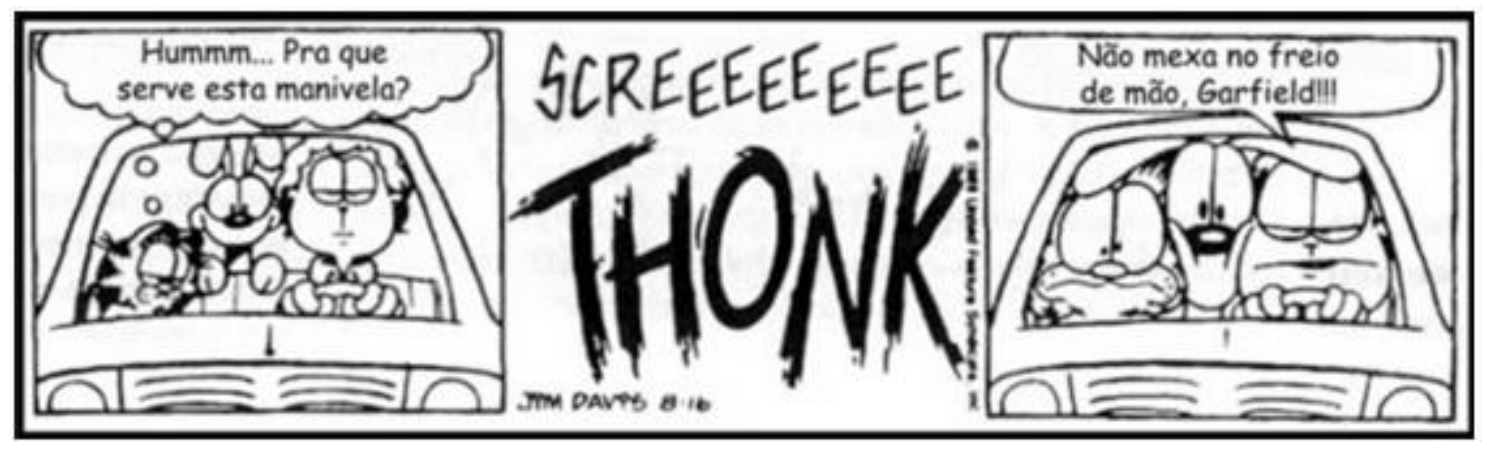


13. (Uerj 2009) Um avião sobrevoa, com velocidade constante, uma área devastada, no sentido sul-norte, em relação a um determinado observador.A figura a seguir ilustra como esse observador, em repouso, no solo, vê o avião. Quatro pequenas caixas idênticas de remédios são largadas de um compartimento da base do avião, uma a uma, a pequenos intervalos regulares. Nessas circunstâncias, os efeitos do ar praticamente não interferem no movimento das caixas. O observador tira uma fotografia, logo após o início da queda da quarta caixa e antes de a primeira atingir o solo. A ilustração mais adequada dessa fotografia é apresentada em:

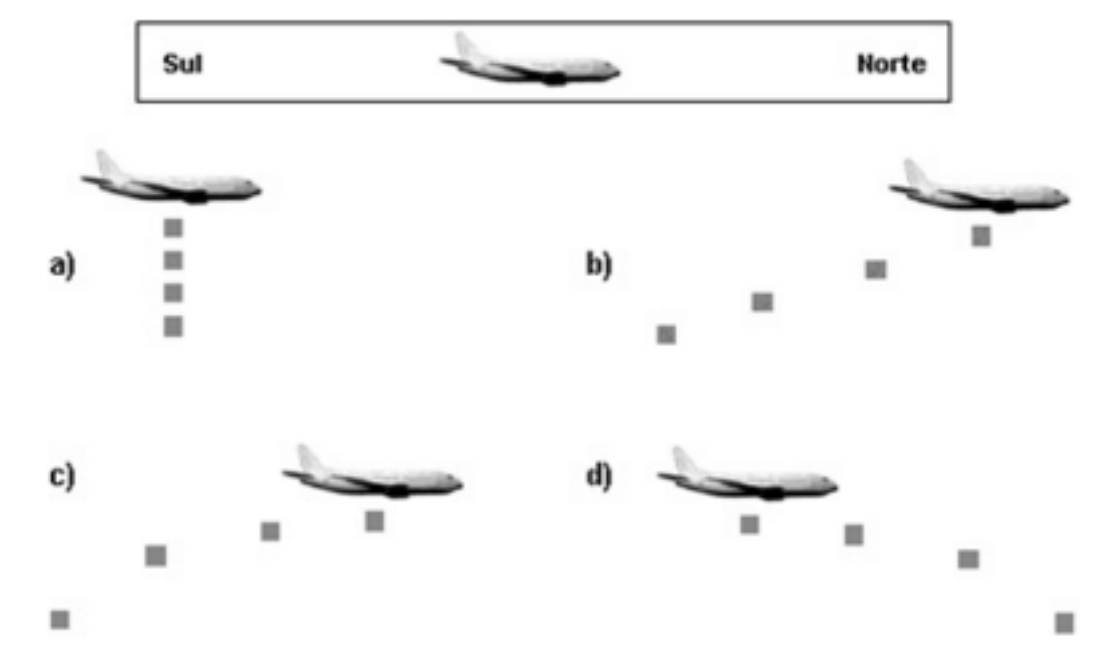

14. (G1 - cftmg 2013) De acordo com a tirinha abaixo, responda qual das alternativas abaixo é correta.

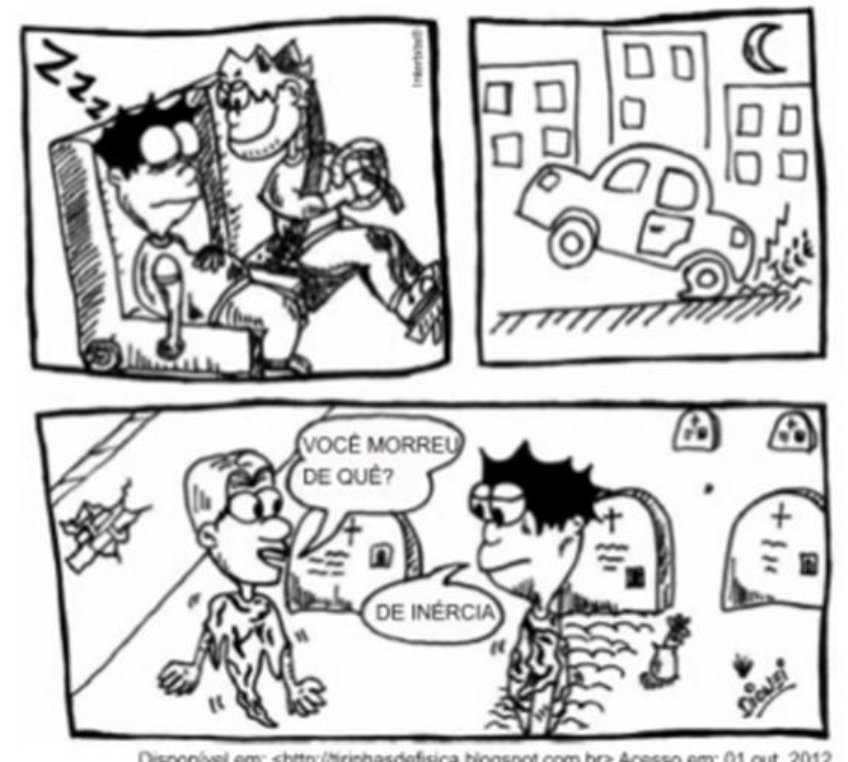


a) mantém-se em repouso e o para-brisa colide contra ele.

b) tende a continuar em movimento e colide contra o para-brisa.

c) é empurrado para frente pela inércia e colide contra o para-brisa.

d) permanece junto ao banco do veículo, por inércia, e o para-brisa colide contra ele. 


\section{Apêndice C \\ PLANOS DAS AULAS}

TEMA: INÉRCIA.

OBJETIVOS

A partir de desenhos animados presentes na realidade do aluno e explicação do conceito, proporcionar entendimento a respeito da lei da Inércia,

\section{PÚBLICO ALVO}

Alunos de uma escola da rede particular de ensino fundamental do 9ํㅡㄴ Ano do ensino fundamental II localizada na região administrativa de Brasília - Asa Sul.

Serão realizadas 4 (quatro) aulas de 50 minutos.

\section{Aula 1 - Pré-Questionário}

Objetivo: Colher dados sobre a visão de física dos estudantes sujeitos dessa pesquisa.

Recursos: Questionário.

\section{Aula 2 - Exibição dos desenhos}

Objetivo: Apresentar e discutir a explicação das cenas vistas pelos estudantes.

Recursos: Computador, Datashow e Sistema de Som.

Atividade desenvolvida: Debate a respeito das cenas.

Conhecimentos prévios necessários aos alunos.

- Velocidade;

- Aceleração;

- Sistemas de referência (referenciais);

- Movimento relativo;

\section{Aula 3}

Objetivo: Aula expositiva dialógica, contextualizada e orientada pela interação alunos - professor - conhecimento. Apresentar o conceito de inércia como apresentado no artigo de Polito (2015). 
"Lei da Inércia: Todo corpo continua em seu estado de repouso, ou movimento uniforme em linha reta, a menos que ele seja compelido a mudar este estado em razão de uma força impressa sobre ele".

Desenvolvimento da aula: A aula será desenvolvida a partir da exposição de conteúdos com abordagem histórica, de exemplos e analogias, de questionamentos propostos aos alunos e do diálogo com eles. Estes procedimentos buscam estimular os alunos e contribuir para com a aprendizagem dos conceitos fundamentais previstos para a aula.

Recursos: Quadro Branco e marcador para quadro branco

\section{Aula 4}

\section{Experimentos e Pós-questionário.}

Objetivo: Permitir aos estudantes que após visualização do conceito nos desenhos animados, percebam esse conceito aplicados em dois experimentos.

Recursos: Esfregão, moeda, papel cartão e copo..

Avaliação: Aplicação de um pós-questionário com o intuito de avaliar o que os estudantes conseguiram assimilar. Os objetivos propostos para as aulas serão avaliados após o término dessa aula e, caso não tenham sido atingidos, outras aulas e atividades serão utilizadas para que os objetivos sejam alcançados.

\section{Bibliografia:}

- HALLIDAY, D., RESNICK, R., e WALKER, J. Fundamentos de Física, 4.ed. vol. 1. Rio de Janeiro: editora LTC, 1996.

- PAUL G. HEWITT. Física Conceitual. Porto Alegre: Bookman, 2002. 


\section{Apêndice D}

\section{Questionário Pós - Teste}

O presente questionário é parte da pesquisa do projeto de Dissertação de Mestrado "Ensino de Física no 9ำ Ano do Ensino fundamental II com desenhos animados uma abordagem lúdica do conceito de inércia - DF", realizado por Diego Veríssimo Pereira, aluno de mestrado do Programa MNPEF-UnB.

Este questionário deve permanecer anônimo, assim, solicito a gentileza de não incluir dados pessoais como nome completo, documentos (RG, CPF, RNE), e dados para contato (telefones, endereço, e-mails e outras mídias sociais, como Facebook, Twitter, Tumblr, etc).

O realizador do presente questionário agradece a sua participação.

Leia atentamente o questionário e responda as seguintes perguntas com relação ao uso de Futurama na aula de física:

1. Futurama me ajudou a compreender melhor o conceito de inércia? Como?

2. Após assistir Futurama, consegui resolver as questões relacionadas à inércia com maior facilidade? Por quê?

3. Qual a sua opinião sobre ter aulas ilustradas com desenhos animados? 
4. Deixe um comentário sobre o projeto. 